\title{
Proposed UNIFORMAT II Classification of Bridge Elements
}

Muthiah Kasi and Robert E. Chapman
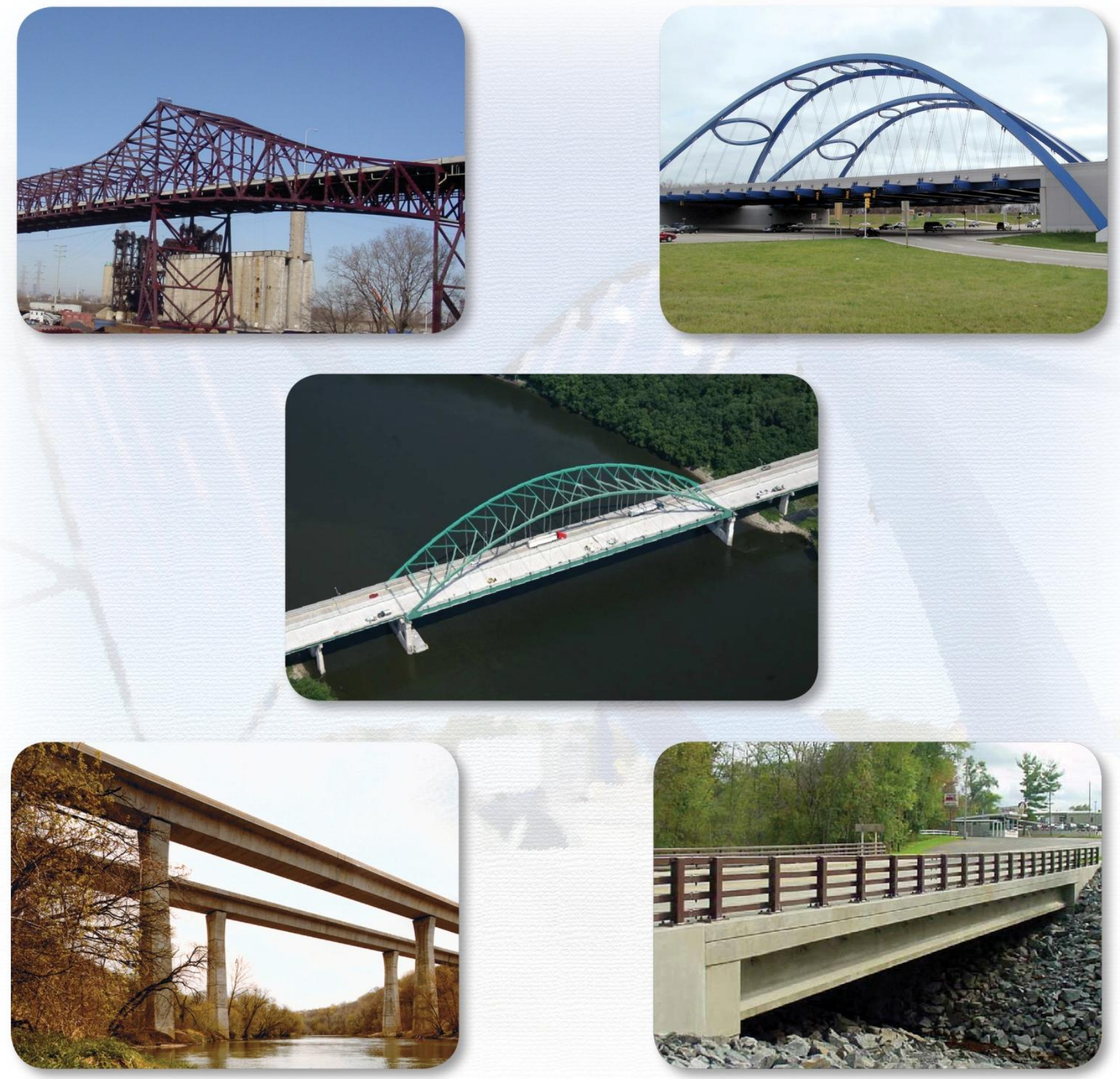



\section{Proposed UNIFORMAT II Classification of Bridge Elements}

Muthiah Kasi and Robert E. Chapman

Sponsored by:

National Institute of Standards and Technology

Engineering Laboratory

May 2011

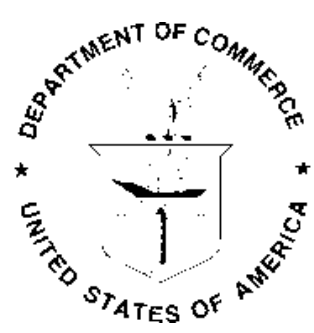

\section{U.S. DEPARTMENT OF COMMERCE}

Gary Locke, Secretary

\section{NATIONAL INSTITUTE OF STANDARDS AND TECHNOLOGY}

Patrick D. Gallagher, Director 



\begin{abstract}
This report presents a proposed UNIFORMAT II classification of bridge elements. Elemental classifications differ from traditional product-related classifications because their core concept is an element that performs a given function, regardless of the design specification, construction method, or materials used. The proposed classification represents a major revision and restructuring of ASTM Standard Classification E 2103, a bridge-related standard classification first issued by ASTM in 2000. The original bridge classification, E 2103, differed from the UNIFORMAT II elemental classification hierarchy in several ways which limited its applicability. The major revisions to E 2103 described in this report will promote its relevance, understanding, and acceptance in the bridge industry. Once approved and reissued by ASTM, the UNIFORMAT II Standard Classification of Bridge Elements, E 2103, will provide the basis for a comprehensive data set of bridge-related costs that will enable public and private decision makers to choose more cost-effective solutions for the design and construction of new bridges and the maintenance and repair of existing bridges across the Nation.
\end{abstract}

A set of alphanumeric designators for the proposed multi-level bridge classification is included. Because many users are interested in constructing databases for use in cost analyses associated with project planning, design, construction, maintenance and repair, and condition assessment, alphanumeric designators provide the basis for compiling, organizing, and referencing cost data.

This report also includes a proposed list of sub-elements for bridges. The UNIFORMAT II hierarchy consists of three levels: Level 1, Major Group Elements; Level 2, Group Elements; and Level 3, Individual Elements. Thus, the core concept of an element resides at Level 3. However, because elements are major components of a constructed entity, there is often ambiguity of what exactly is included in an Individual Element and what should be rightfully excluded from it. Because sub-elements can be tied into a work breakdown structure, they significantly enhance the usefulness of an elemental classification across all project participants throughout the lifecycle of bridges and other constructed entities.

\title{
Keywords:
}

Bridges; construction; cost estimation; economic analysis; functional elements; life-cycle cost; risk analysis; standards; UNIFORMAT II; value engineering 


\section{Preface}

This report produces a proposed classification of bridge elements that will provide the basis for a standard classification of bridge elements to be issued by ASTM International. The material presented in this report will also provide the basis for a comprehensive data set of bridge-related costs that will enable public and private decision makers to choose more cost-effective solutions for the design and construction of new bridges and the maintenance and repair of existing bridges across the Nation. The intended audience is the National Institute of Standards and Technology, the bridge industry, standards and codes developers, the American Association of State Highway and Transportation Officials, the American Society of Civil Engineers, and other construction industry stakeholders interested in improving interdisciplinary communications and in reducing the costs of designing, constructing, and maintaining the Nation's physical infrastructure.

\section{Disclaimer}

Certain trade names and company products are mentioned in the text in order to adequately specify the technical procedures and equipment used. In no case does such identification imply recommendation or endorsement by the National Institute of Standards and Technology, nor does it imply that the products are necessarily the best available for the purpose.

\section{Disclaimer Regarding Non-Metrics Units}

The policy of the National Institute of Standards and Technology is to use metric units in all of its published materials. Because this report is intended for the U.S. construction industry that uses U.S. customary units, it is more practical and less confusing to include U.S. customary units as well as metric units. Measurement values in this report are therefore stated in metric units first, followed by the corresponding values in U.S. customary units within parentheses.

\section{Cover Photographs Credits}

The cover photographs were provided by Alfred Benesch \& Company.

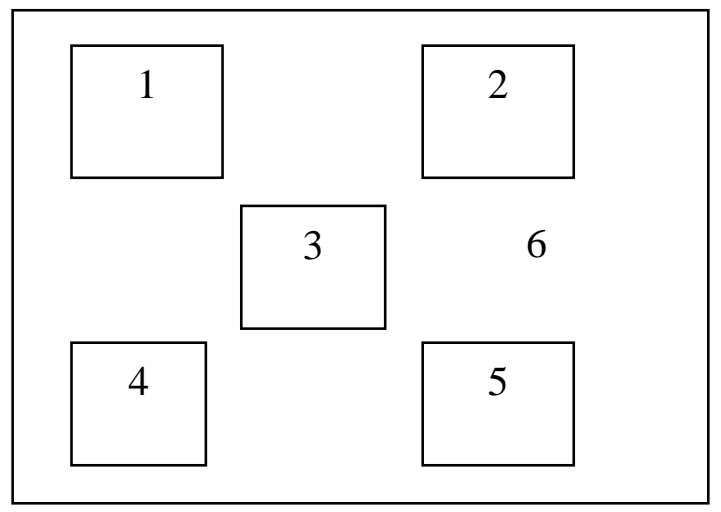

The bridges associated with each cover photograph are as follows: (1) Chicago Skyway, Chicago, Illinois; (2) Gateway Arch Bridge, Taylor, Michigan; (3) Abe Lincoln Memorial Bridge, LaSalle County, Illinois; (4) I-39 over Kishwaukee River, Winnebago County, Illinois;(5) USH 12 over Coffee Creek, Black River Falls, Wisconsin; and (6) ghosting of the Gateway Arch Bridge superstructure. 


\begin{abstract}
Author Affiliations
Muthiah Kasi, PE SE CVS, serves as Chairman of the Board at Alfred Benesch \& Company. Mr. Kasi joined Alfred Benesch \& Company in 1969. His experience at Benesch includes design and management of high rise and low rise buildings, long span river bridges and short span bridges, and urban and rural highways. Mr. Kasi is the Chairman of the ASTM Subcommittee on Building Economics, where for nearly 20 years he has been active in developing standards covering the design, construction, and operation of constructed facilities.

Robert E. Chapman, Ph.D., is the Chief of the Applied Economics Office in the Engineering Laboratory at the National Institute of Standards and Technology (NIST). Dr. Chapman joined NIST, formerly the National Bureau of Standards, in 1975. As Chief of the Applied Economics Office, he leads a group of economists that evaluate new technologies, processes, government programs, legislation, and codes and standards to determine efficient alternatives and measure their economic impacts. Since 1998, Dr. Chapman has chaired the Task Group on Techniques within the ASTM Subcommittee on Building Economics.
\end{abstract}




\section{Acknowledgements}

The authors wish to thank all those who contributed so many excellent ideas and suggestions for this report. They include: Dr. S. Shyam Sunder, Director of the Engineering Laboratory (EL) at the National Institute of Standards and Technology (NIST); Dr. William Grosshandler, EL Deputy Director for Building and Fire Research; Mr. Mark E. Palmer, EL's Automated and Integrated Infrastructure Construction Processes Program Manager, for their technical guidance, suggestions, and support. Special appreciation is extended to Dr. Ihab Darwish, Dr. Michael N. Goodkind, Mr. Andrew Keaschall, Mr. Robert Tipton, and Ms. Jayne Hill of Alfred Benesch \& Company, for their technical contributions during the drafting and production of this manuscript. Special appreciation is extended to Dr. Christopher U. Brown of the EL's Building Environment Division and Dr. David T. Butry and Dr. Harold E. Marshall of the EL's Applied Economics Office for their thorough reviews and many insights. Special appreciation is extended to Ms. Jayne Hill of Alfred Benesch \& Company for her cover design and graphics skills and to Ms. Carmen L. Pardo of the EL's Applied Economics Office for her assistance in preparing the manuscript for review and publication. Special appreciation is also extended to Ms. Barbara Balboni, Senior Engineer RS Means; Mr. Robert P. Charette, Adjunct Professor Concordia University; Mr. Anthony L. Huxley, Construction Consultant; and Mr. Stephen Mawn, Manager Committee E06 on Performance of Buildings ASTM International, for their comments on an earlier draft of this report. The report has also benefitted from the review and technical comments provided by Dr. Nicos S. Martys of the EL's Materials and Construction Research Division. We also acknowledge and express our gratitude to the Illinois Department of Transportation (IDOT) for granting permission to reproduce diagrams from the IDOT Bridge Standards document in Appendix B: An Illustrated Guide to the Proposed UNIFORMAT II Classification of Bridge Elements. The diagrams from the IDOT Bridge Standards document reproduced in this report were in effect on March 25, 2011. We also acknowledge and express our gratitude to the Michigan Department of Transportation for granting permission to use the Gateway Arch Bridge as a case illustration of the proposed UNIFORMAT II classification. The case illustration is presented in Appendix C. 


\section{Table of Contents}

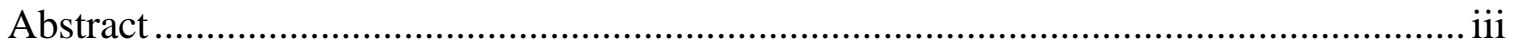

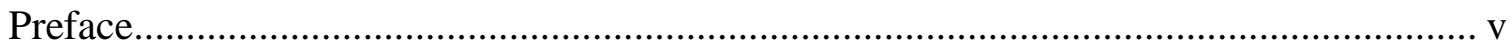

Acknowledgements .............................................................................................. vii

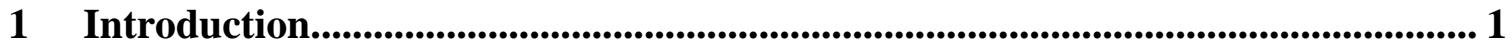

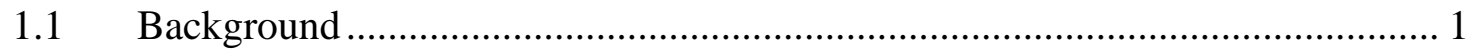

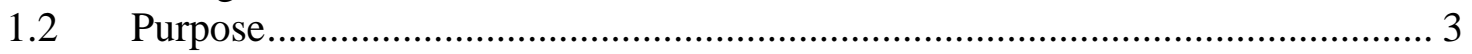

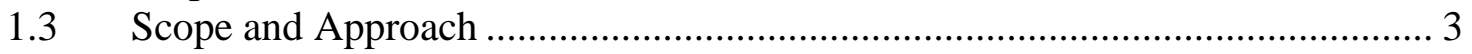

2 Proposed UNIFORMAT II Classification of Bridge Elements ........................... 5

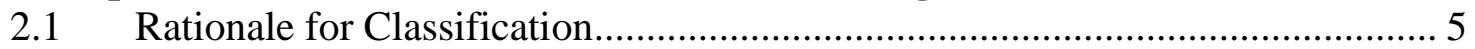

2.2 How the Proposed Classification will be Used ............................................... 6

2.3 Basis of Classification............................................................................... 9

2.4 Description of Proposed UNIFORMAT II Bridge Elements ......................... 12

3 Summary and Recommendations for Further Research ..................................... 31

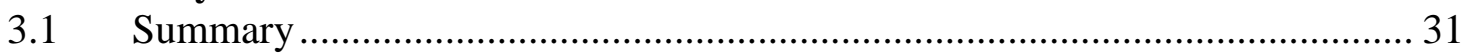

3.2 Recommendations for Further Research.................................................. 31

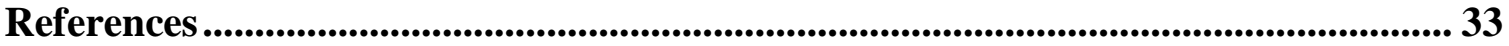

Appendix A Suggested Sub-Classifications of Bridge Elements ............................. 37

Appendix B An Illustrated Guide to the Proposed UNIFORMAT II Classification

of Bridge Elements.................................................................................................................. 51

Appendix C Application of Proposed UNIFORMAT II Classification and Sub-

Classifications to a Single-Span, Modified Tied-Arch Bridge ............................. 79

C.1 Summary of Key Bridge Characteristics ..................................................... 79

C.2 Cost Accounting Framework .................................................................... 85

C.3 Cost Analysis of the Gateway Arch Bridge Using the Proposed UNIFORMAT

II Elemental Classification and Sub-Classifications .................................................. 87

\section{List of Figures}

Figure B.1 Major Group Elements: A Substructure, B Superstructure ......................... 51

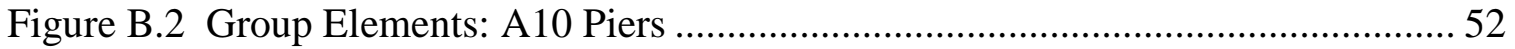

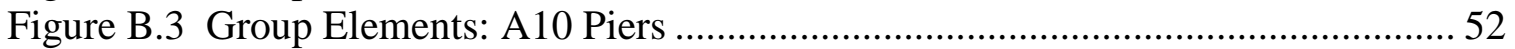

Figure B.4 Individual Elements: A1010 Foundations (Field Requirements: A101010X1

(Cofferdam))

Figure B.5 Individual Elements: A1010 Foundations (Sub-Elements: A101010 Spread

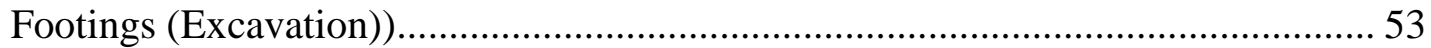

Figure B.6 Individual Elements: A1010 Foundations (Sub-Elements: A101020 Piles) . 54

Figure B.7 Individual Elements: A1010 Foundations (Sub-Elements: A101030 Drilled

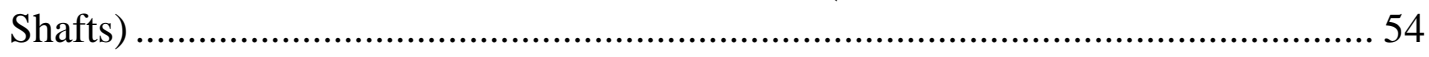

Figure B.8 Individual Elements: A1020 Walls, A1030 Columns, A1040 Cap Beams ... 55 
Figure B.9 Individual Elements: A1040 Cap Beams (Sub-Elements: A10401020

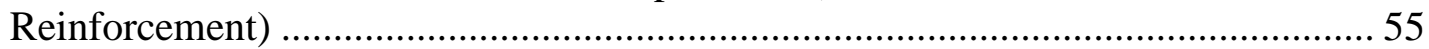

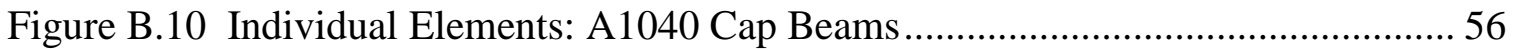

Figure B.11 Group Elements: A20 Towers .............................................................. 56

Figure B.12 Group Elements: A30 Abutments..................................................... 57

Figure B.13 Individual Elements: A3010 Foundations, A3020 Stems, A3030 Wing Walls

Figure B.14 Individual Elements: A3010 Foundations (Sub-Elements: A301020 Piles,

A30102030 Pile Cap)................................................................................. 58

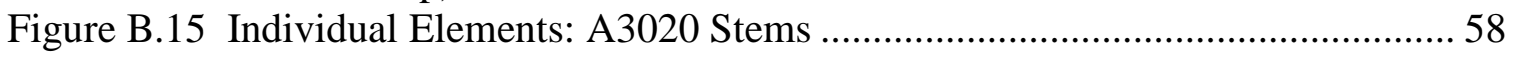

Figure B.16 Individual Elements: A3030 Wing Walls ............................................... 59

Figure B.17 Group Elements: A40 Other Supports (Individual Elements: A4010 Thrust

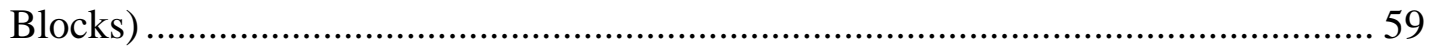

Figure B.18 Individual Elements: A4010 Thrust Blocks (Sub-Elements: A401020

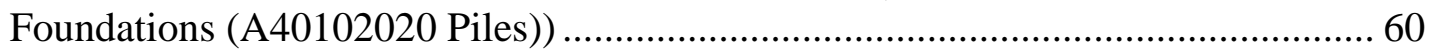

Figure B.19 Group Elements: B10 Short Span Assemblies (Individual Elements: B1010

Flexural Member, B1020 Diaphragms), B30 Deck ............................................ 60

Figure B.20 Individual Elements: B1010 Flexural Members, B1020 Diaphragms ......... 61

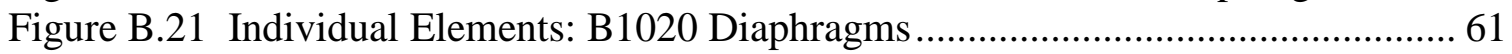

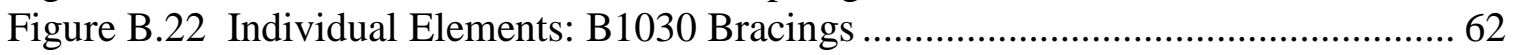

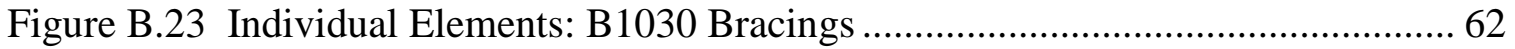

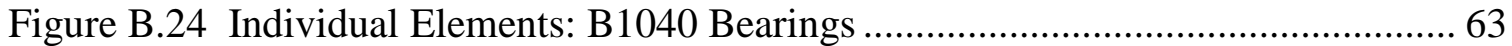

Figure B.25 Individual Elements: B1010 Flexural Members, B1030 Bracings, B1040

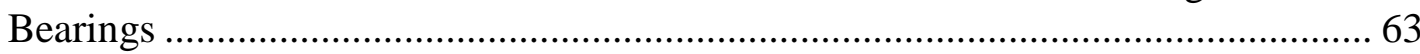

Figure B.26 Group Elements: B20 Long Span Assemblies (Individual Elements: B2010

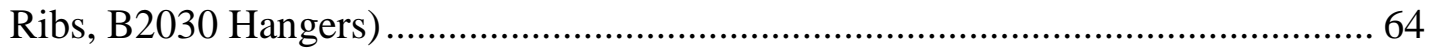

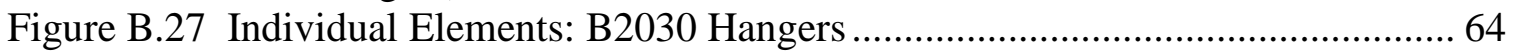

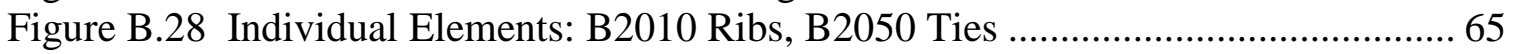

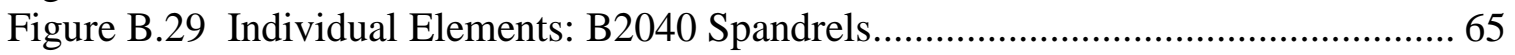

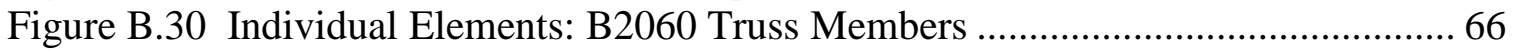

Figure B.31 Individual Elements: B2070 Segmental Box Girders ................................ 66

Figure B.32 Group Elements: B30 Deck (Individual Elements: B3010 Structural

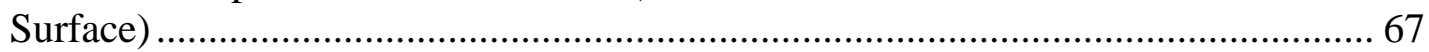

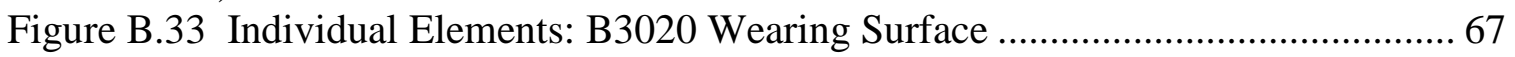

Figure B.34 Group Elements: C10 Structure Protection (Individual Elements:C1010

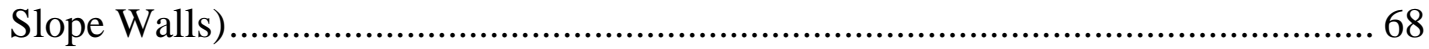

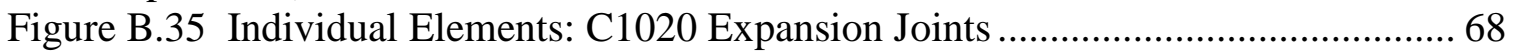

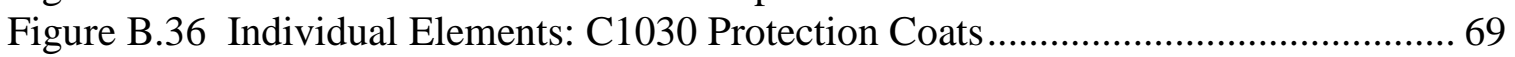

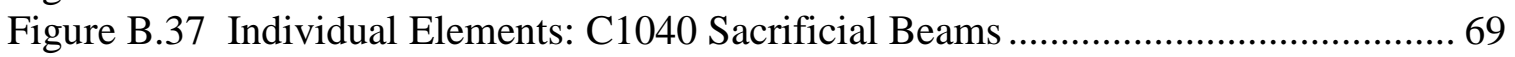

Figure B.38 Individual Elements: C1050 Drainage Systems ...................................... 70

Figure B.39 Individual Elements: C1050 Drainage Systems (Sub-Elements C105030

Buried Drains (C10503020 Head Walls, C10503030 End Walls)) ......................... 70

Figure B.40 Individual Elements: C1060 Inspection and Maintenance Systems ............ 71

Figure B.41 Individual Elements: C2010 Barriers ................................................... 71

Figure B.42 Group Elements: C30 Other Protection (Individual Elements: C3010

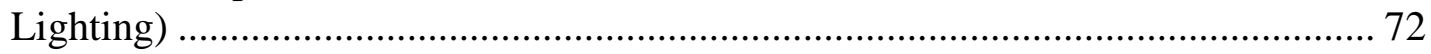


Figure B.43 Individual Elements: C3010 Lighting, C3020 Signage ............................ 72

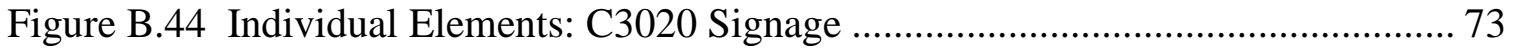

Figure B.45 Individual Elements: C3030 Sound Barrier Walls ................................... 73

Figure B.46 Individual Elements: C3050 Enclosure ................................................ 74

Figure B.47 Major Elements: D Sitework (Group Elements: D10 Site Preparation

(Individual Elements: D1010 Clearing and Grubbing)) ...................................... 74

Figure B.48 Individual Elements: D1010 Clearing and Grubbing (Sub-Element D101010

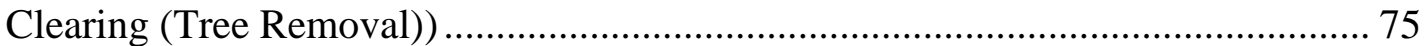

Figure B.49 Group Elements: D10 Site Preparation (Individual Elements: D1020

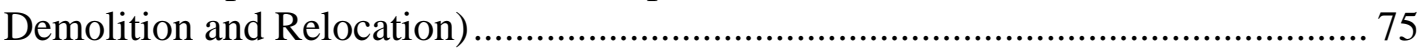

Figure B.50 Individual Elements: D1020 Demolition and Relocation.......................... 76

Figure B.51 Individual Elements: D1030 Earthwork ….......................................... 76

Figure B.52 Group Elements: D20 Approach Construction (Individual Elements: D2010

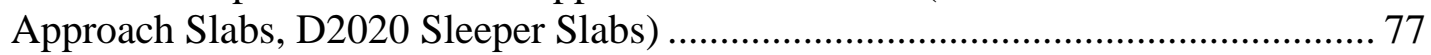

Figure B.53 Individual Elements: D2030 Earth Retention System ................................ 77

Figure C.1 Overhead View of the Gateway Arch Bridge ......................................... 79

Figure C.2 Gateway Arch Bridge as Seen from Telegraph Road ............................... 80

Figure C.3 Gateway Arch Bridge as Seen from I-94 .............................................. 80

Figure C.4 Gateway Arch Bridge Foundation System ........................................... 81

Figure C.5 Longitudinal View of the Arch Ribs.................................................... 82

Figure C.6 Transverse View of the Arch Ribs Illustrates Unequal Lengths ................ 83

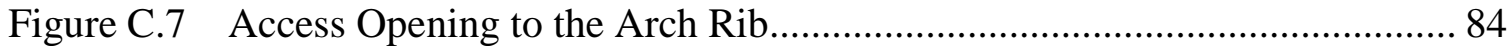

Figure C.8 Hanger Assembly and Neoprene Transition Boots.................................. 84

Figure C.9 Cost Distribution of Selected Group Elements and Individual Elements for

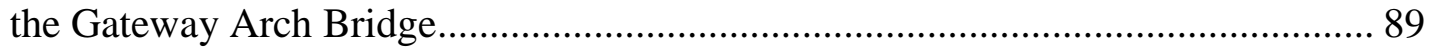

\section{List of Tables}

Table 2.1 List of Constructed Entities Suitable for Inclusion in the Family of

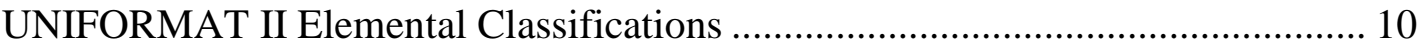

Table 2.2 Proposed UNIFORMAT II Classification of Bridge Elements ...................... 11

Table 2.3 Description of Proposed UNIFORMAT II Bridge Elements ........................ 14

Table A.1 Suggested Sub-Classifications of Bridge Elements ..................................... 38

Table C.1 Classification Hierarchy for Program Management-Related Costs ............... 86

Table C.2 Classification Hierarchy for Risk Management-Related Costs ..................... 86

Table C.3 Cost Analysis of the Gateway Arch Bridge Using the Proposed UNIFORMAT

II Elemental Classification and Sub-Classifications .............................................. 88 


\section{Introduction}

\subsection{Background}

The use of elemental classifications for improved budget planning and cost control for building-related projects began shortly after the end of World War II. Elemental classifications differ from the traditional "product-related" classifications because their core concept is an "element" that performs a given function, regardless of the design specification, construction method, or materials used. Thus, elemental classifications support a structured approach for developing budget estimates during the planning and conceptual design stages where quantity takeoffs and other product-related information are still under development.

The initial applications of elemental classifications were in the UK, where they were used for budgeting funds to repair educational facilities damaged or destroyed during World War II and to build new facilities to meet increased demands due to population growth. The UK successes with budgeting and cost control for educational facilities led to applications in other building types within the UK and ultimately in other parts of Europe. By the 1960s, the use of elemental classifications for budgeting and estimating the costs of the design and construction of commercial and institutional buildings had spread throughout the British Commonwealth and many other parts of the world. ${ }^{1}$

The use of elemental classifications for commercial and institutional buildings in the USA began in the 1950s. These initial applications were led by the General Services Administration (GSA) and the American Institute of Architects (AIA). The interest in producing a common framework that could be used by all stakeholders in the design, construction, and operation of commercial and institutional buildings led to the creation of UNIFORMAT in $1975 .^{2}$

The initial success of UNIFORMAT stimulated interest in expanding its capabilities to other types of constructed entities. In the late 1980s, a broad-based effort under the auspices of the Building Economics Subcommittee of ASTM International was launched to produce a standard classification of building elements and related sitework. ${ }^{3}$ The resulting standard, E 1557, was first issued by ASTM in 1993. Over the ensuing years, E 1557-refered to as UNIFORMAT II to highlight its linkage to the earlier UNIFORMAT document - has been revised and expanded to meet new and emerging needs. ${ }^{4}$

\footnotetext{
${ }^{1}$ Royal Institute of Chartered Surveyors (RICS). 1969. Standard Form of Cost Analysis. London, England: The Building Cost Information Service.

${ }^{2}$ Hanscomb Associates, Inc. 1975. Automated Cost Control and Estimating System. Washington, DC: General Services Administration.

${ }^{3}$ Brian Bowen, Robert P. Charette, and Harold E. Marshall. 1992. UNIFORMAT II: A Recommended Classification for Building Elements and Related Sitework, NIST Special Publication 841. Gaithersburg, MD: National Institute of Standards and Technology.

${ }^{4}$ ASTM International. "Classification of Building Elements and Related Sitework-UNIFORMAT II,"

E 1557, Annual Book of ASTM Standards: 2010, Vol. 4.11. West Conshohocken, PA: ASTM International.
} 
The latest version of E 1557 focuses primarily on buildings but has broad applicability to other types of constructed entities. Current applications of E 1557 include: planning estimates; program estimates; preliminary project descriptions; preliminary construction schedules and cash flow projections; design phase estimates; CAD layering and building information modeling (BIM); life-cycle cost analysis reporting; checklists for technical design reviews; project scheduling; construction progress reporting and interim payments; construction claims analysis; building condition assessment; organizing design, engineering, and construction cost information for manuals and databases; and organizing maintenance and life-cycle cost data. ${ }^{5}$

The widespread use of E 1557-it is one of the top selling standards from ASTM's inventory of over 12000 standards - sparked interest in standard classifications for other types of constructed entities. Several ASTM standard classifications were subsequently developed, most notably a bridge-related classification, E 2103. ${ }^{6}$ However, standard classification E 2103 differed from the underlying "elemental" concept that was at the heart of E 1557. To address the need for a more rigorous "family" of classification standards based on the UNIFORMAT II elemental concept, the Building Economics Subcommittee, ASTM E06.81, formed a task group charged with the development of a set of "Guidelines for Developing UNIFORMAT II Standard Classifications." The UNIFORMAT II Guidelines were first approved by the Building Economics Subcommittee in April 2009 and were posted on the ASTM E06.81 web site in May 2009. ${ }^{8}$

Because bridges are a critical component of the Nation's infrastructure and many bridges are in need of significant capital outlays over the coming years to both remedy safety concerns and build new capacity for multiple modes of transportation, ${ }^{9}$ a major revision to the existing bridge classification, E 2103, is both timely and appropriate. At the October 2009 ASTM E06.81 meeting, a motion was passed to completely revise and restructure E 2103 to be fully consistent with the UNIFORMAT II Guidelines document. Plans for revising and restructuring E 2103 were presented at the April 2010 and October 2010 ASTM E06.81 meetings. This report expands on those plans by providing an indepth description of what the restructured version of E 2103 will include to bring it into full compliance with the UNIFORMAT II Guidelines document. Two major extensions to the proposed UNIFORMAT II classification of bridge elements are also presented. Once approved and reissued by ASTM, the UNIFORMAT II Standard Classification of Bridge Elements, E 2103, will provide the basis for a comprehensive data set of bridge-

\footnotetext{
${ }^{5}$ Robert P. Charette and Harold E. Marshall. 1999. UNIFORMAT II: Elemental Classification for Building Specifications, Cost Estimating, and Cost Analysis, NISTIR 6389. Gaithersburg, MD: National Institute of Standards and Technology.

${ }^{6}$ ASTM International. "Classification of Bridge Elements and Related Approach Work," E 2103, Annual Book of ASTM Standards: 2010, Vol. 4.12. West Conshohocken, PA: ASTM International.

${ }^{7}$ ASTM International. "Guidelines for Developing UNIFORMAT II Standard Classifications," Working Paper. West Conshohocken, PA: ASTM International.

${ }^{8} \mathrm{http} / / /$ www.astm.org/COMMIT/SUBCOMMIT/E0681.htm (accessed December 2010).

9 ASCE 2009 Report Card for America's Infrastructure. http://www.infrastructurereportcard.org/ (accessed December 2010).
} 
related costs that will enable public and private decision makers to choose more costeffective solutions for the design and construction of new bridges and the maintenance and repair of existing bridges across the Nation.

\subsection{Purpose}

The purpose of this report is threefold. First and foremost, it presents a proposed UNIFORMAT II classification of bridge elements. The proposed classification represents a major revision and restructuring of ASTM Standard Classification E 2103 first issued in 2000 and reissued in 2006. The original bridge classification, E 2103, differed from the UNIFORMAT II elemental classification hierarchy in several ways which limited its applicability. The proposed major revision and restructuring presented in this report is fully consistent with the UNIFORMAT II Guidelines document established by the ASTM E06.81 Subcommittee on Building Economics. These major revisions to $\mathrm{E} 2103$ will promote its relevance, understanding, and acceptance in the bridge industry.

Second, this report includes a set of alphanumeric designators for the proposed multilevel bridge classification. Because many users are interested in constructing databases for use in cost analyses associated with project planning, design, construction, maintenance and repair, and condition assessment, alphanumeric designators provide the basis for compiling, organizing, and referencing cost data. Having a common set of alphanumeric designators promotes consistency in use among the key project participants and other stakeholders associated with the design, construction, and use of bridges and other constructed entities.

Third, this report includes a proposed list of sub-elements for bridges. As noted earlier, the primary focus of the UNIFORMAT II Standard Classification E 1557 and its associated family is on the elemental concept. The UNIFORMAT II hierarchy consists of three levels: Level 1, Major Group Elements; Level 2, Group Elements; and Level 3, Individual Elements. Thus, the core concept of an element resides at Level 3. All three levels are treated in detail in the body of this report and are intended to serve as the basis for the proposed revisions to E 2103. However, because elements-Level 3 in a UNIFORMAT II hierarchy - are major components of a constructed entity (e.g., a bridge), there is often ambiguity of what exactly is included in an Individual Element and what should be rightfully excluded from it. By providing a proposed set of sub-elements as an appendix, this report lays the framework for evaluating the merits of including such a list in E 2103 along with the other proposed revisions discussed in the body of the text. Because sub-elements can be tied into a work breakdown structure, they significantly enhance the usefulness of an elemental classification across all project participants throughout the lifecycle of bridges and other constructed entities.

\subsection{Scope and Approach}

The report consists of two chapters and three appendices in addition to the Introduction. Chapter 2 presents the proposed UNIFORMAT II classification of bridge elements. The 
chapter first discusses the rationale for undertaking a major revision of the original E 2103 bridge classification to make it consistent with the UNIFORMAT II Guidelines document established by the ASTM E06.81 Subcommittee on Building Economics. The potential uses of the proposed bridge classification are then discussed. The proposed bridge classification is then described and summarized as a hierarchy with three levels: Level 1, Major Group Elements; Level 2, Group Elements; and Level 3, Individual Elements. The chapter concludes with an element-by-element description of the proposed bridge classification.

Chapter 3 provides a summary and recommendations for further research. Specifically, four additional UNIFORMAT II classifications are proposed for development: (1) tunnels; (2) highways; (3) railroads; and (4) water treatment and distribution. Each of these classifications corresponds to a critical infrastructure need identified in the American Society of Civil Engineers Report Card for America's Infrastructure. ${ }^{10}$

Appendix A presents suggested sub-classifications of bridge elements. The subclassifications expand the Level 3 Individual Elements into their constituent parts. These constituent parts include a Level 4 for all Individual Elements and, where necessary, a Level 5 (i.e., subdivisions of Level 4).

Appendix B is designed as an illustrated guide to the proposed UNIFORMAT II classification of bridge elements. The appendix includes diagrams, engineering drawings, and, where appropriate, photographs to identify the appearance of each element and how it fits into the overall framework.

Appendix $\mathrm{C}$ uses a case study bridge construction project to demonstrate how to use the proposed UNIFORMAT II classification and sub-classifications to analyze and manage bridge design and construction costs. The bridge is a single-span, modified tied-arch carrying Interstate 94 (I-94) over Telegraph Road in Taylor, Michigan. This bridge was part of the reconstruction of I-94 for the Super Bowl XL game held in 2006.

${ }^{10}$ ASCE 2009 Report Card for America's Infrastructure, op cit. 


\section{Proposed UNIFORMAT II Classification of Bridge Elements}

\subsection{Rationale for Classification}

The Engineering Laboratory at NIST has launched the Automated and Integrated Infrastructure Construction Processes Program to investigate the challenges and evolving technologies needed to enable the construction industry to develop best practices, protocols, and standards to achieve breakthrough improvements in construction productivity and the delivery of physical infrastructure. The timely and cost effective delivery of physical infrastructure is a critical national need. The ASCE Report Card for America's Infrastructure highlights the need for maintaining a robust infrastructure to promote the Nation's current standard of living and to advance its competitiveness. Unfortunately, much of the Nation's physical infrastructure is nearing the end of its service life and needs to be repaired or replaced. ASCE estimates the cost of renewing existing, critical infrastructure to be $\$ 2.2$ trillion. ${ }^{11}$

Bridges are an important part of the Nation's physical infrastructure. Although bridges are usually built to last 50 years, AASHTO estimates that the average bridge in the USA is 43 years old. ${ }^{12}$ More than $26 \%$, or one in four, of the Nation's 609905 bridges are either structurally deficient or functionally obsolete. A $\$ 17$ billion annual investment is needed to substantially improve current bridge conditions. Currently, only $\$ 10.5$ billion is spent annually on the construction and maintenance of bridges. ${ }^{13}$

In response to this challenge, this report presents a proposed classification of bridge elements within the UNIFORMAT II family of elemental classifications that covers most highway bridges, railroad bridges, and pedestrian bridges. The proposed classification represents a major revision and restructuring of ASTM Standard Classification E 2103, ${ }^{14}$ a bridge-related standard classification first issued by ASTM in 2000. The original bridge classification, E 2103, differed from the UNIFORMAT II elemental classification hierarchy ${ }^{15}$ in several ways which limited its applicability. The major revisions to E 2103 described in this chapter will promote its relevance, understanding, and acceptance in the bridge industry. Once approved and reissued by ASTM, the UNIFORMAT II Standard Classification of Bridge Elements, E 2103, will provide the basis for a comprehensive data set of bridge-related costs that will enable public and private decision makers to choose more cost-effective solutions for the design and construction of new bridges and the maintenance and repair of existing bridges across the Nation.

\footnotetext{
${ }^{11}$ ASCE 2009 Report Card for America's Infrastructure, op cit.

${ }^{12}$ American Association of State Highway and Transportation Officials (AASHTO). 2008. Bridging the Gap. Washington, DC: AASHTO.

${ }^{13}$ American Society of Civil Engineers. 2009. Facts About Bridges.

${ }^{14}$ ASTM International. E 2103, "Classification of Bridge Elements and Related Approach Work," op cit.

${ }^{15}$ ASTM International. E 1557, "Classification of Building Elements and Related Sitework-

UNIFORMAT II," op cit.
} 
UNIFORMAT II classifications have an elemental format similar to the original UNIFORMAT ${ }^{16}$ building elemental classification. However, the title UNIFORMAT II differs from the original in that it now takes into consideration a wide range of constructed entities that collectively form the "Built Environment." Elements, as defined here, are major physical components that are common within constructed entities. Elements perform their given function(s), regardless of the design specification, construction method, or materials used. This proposed elemental classification serves as a consistent reference for analysis, evaluation, and monitoring during the feasibility, planning, and design stages when constructing bridges.

Using the UNIFORMAT II Guidelines document ${ }^{17}$ to develop elemental classifications ensures a consistency in the economic evaluation of construction projects over time and from project to project. UNIFORMAT II classifications also enhance reporting at all stages of a constructed entity's life cycle - from feasibility and planning through the preparation of working documents, construction, maintenance, rehabilitation, and disposal.

\subsection{How the Proposed Classification will be Used}

The proposed UNIFORMAT II classification presented in this report describes bridge elements that are major components of most highway, railroad, and pedestrian bridges. This section covers both the potential users of the proposed UNIFORMAT II classification of bridge elements and the various ways in which the proposed classification can be used to promote more cost-effective bridges throughout their lifecycle. ${ }^{18}$ The elemental classification is the common thread linking activities and participants in a bridge project from initial planning through operations, maintenance, and disposal.

As the proposed UNIFORMAT II classification of bridge elements refers solely to permanent, physical parts of any bridge construction, two ASTM Standard Classifications, $E 2083^{19}$ and E $2168,{ }^{20}$ need to be included when calculating construction cost. These standards provide for the inclusion of construction enabling, temporary, and risk mitigation cost figures. Procedures for reporting all these figures are

\footnotetext{
16 The original UNIFORMAT classification was developed jointly by the General Services Administration (GSA) and the American Institute of Architects (AIA).

${ }^{17}$ ASTM International. "Guidelines for Developing UNIFORMAT II Standard Classifications," op cit.

${ }^{18}$ For additional information on the uses of ASTM Standard Classification E 1557, see Bowen, Charette, and Marshall, UNIFORMAT II-A Recommended Classification for Building Elements and Related Sitework, NIST Special Publication 841, op cit, and Charette and Marshall, UNIFORMAT II Elemental Classification for Building Specifications, Cost Estimating, and Cost Analysis, NISTIR 6389, op cit.

${ }^{19}$ ASTM International. "Classification for Building Construction Field Requirements, and Office Overhead and Profit," E 2083, Annual Book of ASTM Standards: 2010, Vol. 4.11. West Conshohocken, PA: ASTM International.

${ }^{20}$ ASTM International. "Classification for Allowance, Contingency and Reserve Sums in Building Construction Estimating,” E 2168, Annual Book of ASTM Standards: 2010, Vol. 4.12. West Conshohocken, PA: ASTM International.
} 
described in ASTM standards E $1804,{ }^{21}$ E $2514,{ }^{22}$ and E $2516 .{ }^{23}$ While these three latter standards were primarily written for building construction, they are nonetheless appropriate and readily applied to other forms of construction as well.

\section{Users of the Proposed UNIFORMAT II Classification of Bridge Elements}

Financial and Investment-Typically owners, developers, bankers, lenders, accountants, and financial managers.

Implementation - Primarily project managers; facilities programmers; designers, including engineers; and project controls specialists, including cost planners, estimators, schedulers, specification writers, and risk analysts.

Facilities Management - Comprising property portfolio managers, operating staff, and maintenance staff.

Others-Public officials, manufacturers, educators, students, and other project stakeholders.

\section{Applications of the Proposed UNIFORMAT II Classification of Bridge Elements}

Financing and Investing - Structuring costs on an elemental basis for economic evaluations (ASTM Standard Practices E $917,{ }^{24} \mathrm{E} 964,{ }^{25} \mathrm{E} 1057,{ }^{26} \mathrm{E} 1074,{ }^{27} \mathrm{E} 1121,{ }^{28}$ and $\mathrm{E} 1804^{29}$ ) early in the design process helps reduce the cost of early financial analysis

\footnotetext{
${ }^{21}$ ASTM International. "Practice for Performing and Reporting Cost Analysis During the Design Phase of a Project," E 1804, Annual Book of ASTM Standards: 2010, Vol. 4.11. West Conshohocken, PA: ASTM International.

${ }^{22}$ ASTM International. "Practice for Presentation Format of Elemental Cost Estimates, Summaries, and Analyses," E 2514, Annual Book of ASTM Standards: 2010, Vol. 4.12. West Conshohocken, PA: ASTM International.

${ }^{23}$ ASTM International. "Classification for Cost Estimate Classification System,” E 2516, Annual Book of ASTM Standards: 2010, Vol. 4.12. West Conshohocken, PA: ASTM International.

${ }^{24}$ ASTM International. "Practice for Measuring Life-Cycle Costs of Buildings and Building Systems," E 917, Annual Book of ASTM Standards: 2010, Vol. 4.11. West Conshohocken, PA: ASTM International.

${ }^{25}$ ASTM International. "Practice for Measuring Benefit-to-Cost and Savings-to-Investment Ratios for Buildings and Building Systems," E 964, Annual Book of ASTM Standards: 2010, Vol. 4.11. West Conshohocken, PA: ASTM International.

${ }^{26}$ ASTM International. "Practice for Measuring Internal Rate of Return and Adjusted Internal Rate of Return for Investments in Buildings and Building Systems," E 1057, Annual Book of ASTM Standards: 2010, Vol. 4.11. West Conshohocken, PA: ASTM International.

${ }^{27}$ ASTM International. "Practice for Measuring Net Benefits and Net Savings for Investments in Buildings and Building Systems," E 1074, Annual Book of ASTM Standards: 2010, Vol. 4.11. West Conshohocken, PA: ASTM International.

${ }^{28}$ ASTM International. "Practice for Measuring Payback for Investments in Buildings and Building Systems,” E 1121, Annual Book of ASTM Standards: 2010, Vol. 4.11. West Conshohocken, PA: ASTM International.

${ }^{29}$ ASTM International. "Practice for Performing and Reporting Cost Analysis During the Design Phase of a Project,” E 1804, op cit.
} 
and can contribute to substantial design and operational savings before decisions have been made that limit options for potential savings.

Cost Modeling, Cost Planning, Estimating and Controlling Project Time and Cost During Planning, Design, and Construction-Use the bridge UNIFORMAT II classification to prepare budgets and to establish elemental cost plans before design begins. Project managers and project controls specialists use these cost plans against which to measure and control project cost, and quality, and to set design-to-cost targets.

Conducting Value Engineering Workshops-Conducting value engineering workshops (ASTM Standard Practices E $1699^{30}$ and E $2013^{31}$ ). Use this classification as a checklist to ensure that alternatives for all elements of significant cost in the bridge project are analyzed in the creativity phase of the job plan. Also, use the elemental cost data to expedite the development of cost models for bridge systems.

Developing Initial Project Master Schedules-Since projects are essentially built element by element, UNIFORMAT II classifications are an appropriate basis for preparing construction schedules at the start of the design process. Project managers and project controls specialists use these time plans against which to measure and control project time (ASTM Standard Practice E 2691 ${ }^{32}$ ), prepare detailed project schedules, and to set milestone target dates.

Performing Risk Analyses-Simulation (ASTM Standard Guides E $1369^{33}$ and E $2506^{34}$ ) is one technique for developing probability distributions of bridge costs when evaluating the economic risk in undertaking a bridge project. Use individual elements and group elements in this classification for developing probability distributions of elemental costs. From these distributions, build up probability distributions of total costs to establish project contingencies (ASTM Standard Practice E $1946^{35}$ and ASTM Standard Classification E $2168^{36}$ ) or to serve as inputs to an economic analysis.

\footnotetext{
${ }^{30}$ ASTM International. "Practice for Performing Value Analysis (VA) of Buildings and Building Systems," E 1699, Annual Book of ASTM Standards: 2010, Vol. 4.11. West Conshohocken, PA: ASTM International.

31 ASTM International. "Practice for Constructing FAST Diagrams and Performing Function Analysis During Value Analysis Study," E 2013, Annual Book of ASTM Standards: 2010, Vol. 4.11. West Conshohocken, PA: ASTM International.

${ }^{32}$ ASTM International. "Practice for Job Productivity Measurement," E 2691, Annual Book of ASTM Standards: 2010, Vol. 4.12. West Conshohocken, PA: ASTM International.

${ }^{33}$ ASTM International. "Guide for Selecting Techniques for Treating Uncertainty and Risk in the Economic Evaluation of Buildings and Building Systems," E 1369, Annual Book of ASTM Standards: 2010, Vol. 4.11. West Conshohocken, PA: ASTM International.

${ }^{34}$ ASTM International. "Guide for Developing a Cost-Effective Risk Mitigation Plan for New and Existing Constructed Facilities," E 2506, Annual Book of ASTM Standards: 2010, Vol. 4.12. West Conshohocken,

PA: ASTM International.

${ }^{35}$ ASTM International. "Practice for Measuring Cost Risk of Buildings and Building Systems," E 1946, Annual Book of ASTM Standards: 2010, Vol. 4.11. West Conshohocken, PA: ASTM International.

${ }^{36}$ ASTM International. "Classification for Allowance, Contingency and Reserve Sums in Building Construction Estimating," E 2168, op cit.
} 
Structuring Preliminary Project Descriptions During the Conceptual Design PhaseThis classification facilitates the description of the scope of the project in a clear, concise, and logical sequence for presentation to the client; it provides the basis for the preparation of more detailed elemental estimates during the early concept and preliminary design phases, and it enhances communication between designers and clients by providing a clear statement of the designer's intent.

Coding and Referencing Standard Details In Computer-Aided Design Systems-This classification allows a designer, for example, to reference an assembly according to this classification's element designations and build up a database of standard details. This is particularly appropriate to design modeling and building information modeling (BIM) applications.

Managing Facilities-Recording and writing property condition assessment reports in a structured way, using UNIFORMAT II classifications, provides for a consistent, accessible, and searchable database of real property inventory.

Other Activities - Structuring cost manuals and recording construction, operating, and maintenance costs in a computer database. Having a cost manual or computer database in an elemental format assists the preparation of an economic analysis early in the design stage and at a reasonable cost.

\subsection{Basis of Classification}

The framework in Table 2.1 shows the two branches that serve to define the built environment - light construction associated with buildings and heavy construction associated with civil structures. Under each branch are listed, the various constructed entities that collectively are used to create the built environment. Each entity is treated as a module, where a module may result in one or more UNIFORMAT II elemental classifications. Appropriate modules, and the standards associated with them, when used together will effectively describe any planned or built development.

The proposed classification covered in this report describes exclusively the elements that make up one of those constructed entities, bridge structures, shown as the shaded block under the heading of Heavy (Civil) Entities. This bridge classification is applicable to most types of highway, railroad, and pedestrian bridges.

The classification includes: slab bridges; beam/girder bridges; truss bridges; true and tied-arch bridges; cable-stayed bridges; and suspension bridges.

The classification does not include the following movable bridge types: draw bridges; lift bridges; and bascule bridges. 
Table 2.1 List of Constructed Entities Suitable for Inclusion in the Family of UNIFORMAT II Elemental Classifications

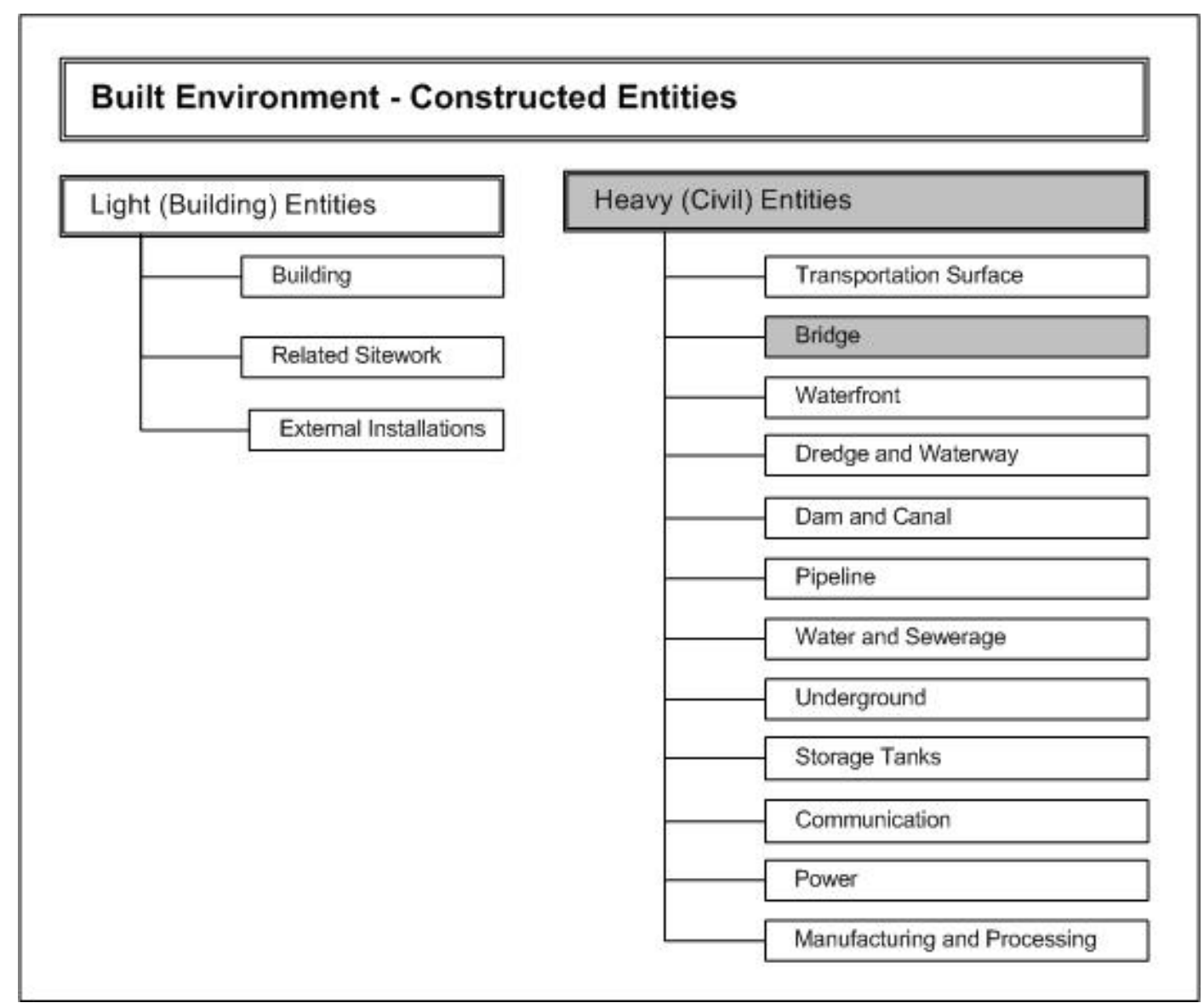

The proposed UNIFORMAT II bridge classification is consistent with typical costing practices used at the conceptual design phase. Each element has a significant impact on the cost, and it usually occurs frequently. Each element performs a specific function.

Table 2.2 divides the classification of bridge elements into three hierarchical levels: Level 1, Major Group Elements; Level 2, Group Elements; and Level 3, Individual Elements. The Major Groups are listed in the normal chronological order of construction. The proposed UNIFORMAT II bridge classification builds on the concepts and organizational framework put forth in the E 1557 standard classification. 
Table 2.2 Proposed UNIFORMAT II Classification of Bridge Elements

\begin{tabular}{|c|c|c|}
\hline $\begin{array}{c}\text { Level 1 } \\
\text { Major Group Elements }\end{array}$ & $\begin{array}{c}\text { Level } 2 \\
\text { Group Elements }\end{array}$ & $\begin{array}{c}\text { Level } 3 \\
\text { Individual Elements }\end{array}$ \\
\hline \multirow[t]{4}{*}{ A Substructure } & A10 Piers & $\begin{array}{l}\text { A1010 Foundations } \\
\text { A1020 Walls } \\
\text { A1030 Columns } \\
\text { A1040 Cap Beams }\end{array}$ \\
\hline & A20 Towers & $\begin{array}{l}\text { A2010 Foundations } \\
\text { A2020 Walls } \\
\text { A2030 Columns } \\
\text { A2040 Cap Beams }\end{array}$ \\
\hline & A30 Abutments & $\begin{array}{l}\text { A3010 Foundations } \\
\text { A3020 Stems } \\
\text { A3030 Wing Walls }\end{array}$ \\
\hline & A40 Other Supports & $\begin{array}{l}\text { A4010 Thrust Blocks } \\
\text { A4020 Anchorages }\end{array}$ \\
\hline \multirow[t]{3}{*}{ B Superstructure } & B10 Short Span Assemblies & $\begin{array}{ll}\text { B1010 } & \text { Flexural Members } \\
\text { B1020 Diaphragms } \\
\text { B1030 } \text { Bracings } \\
\text { B1040 } \text { Bearings }\end{array}$ \\
\hline & B20 Long Span Assemblies & $\begin{array}{l}\text { B2010 Ribs } \\
\text { B2020 Cables } \\
\text { B2030 Hangers } \\
\text { B2040 Spandrels } \\
\text { B2050 Ties } \\
\text { B2060 Truss Members } \\
\text { B2070 Segmental Box Girders }\end{array}$ \\
\hline & B30 Deck & $\begin{array}{l}\text { B3010 Structural Surface } \\
\text { B3020 Wearing Surface }\end{array}$ \\
\hline \multirow[t]{3}{*}{ C Protection } & C10 Structure Protection & $\begin{array}{l}\text { C1010 Slope Walls } \\
\text { C1020 Expansion Joints } \\
\text { C1030 Protective Coats } \\
\text { C1040 Sacrificial Beams } \\
\text { C1050 Drainage Systems } \\
\text { C1060 Inspection and Maintenance Systems }\end{array}$ \\
\hline & C20 Traffic Protection & $\begin{array}{l}\text { C2010 Barriers } \\
\text { C2020 Protective Shields } \\
\text { C2030 Traffic Controls }\end{array}$ \\
\hline & C30 Other Protection & $\begin{array}{ll}\text { C3010 Lighting } \\
\text { C3020 Signage } \\
\text { C3030 Sound Barrier Walls } \\
\text { C3040 Air Pressure Barriers } \\
\text { C3050 Enclosure } \\
\end{array}$ \\
\hline \multirow[t]{2}{*}{ D Sitework } & D10 Site Preparation & $\begin{array}{l}\text { D1010 Clearing and Grubbing } \\
\text { D1020 Demolition and Relocation } \\
\text { D1030 Earthwork } \\
\text { D1040 Hazardous Material Handling } \\
\text { D1050 Environmental Restoration/Replacement }\end{array}$ \\
\hline & D20 Approach Construction & $\begin{array}{l}\text { D2010 Approach Slabs } \\
\text { D2020 Sleeper Slabs } \\
\text { D2030 Earth Retention Systems }\end{array}$ \\
\hline
\end{tabular}


Sub-Classifications (see Appendix A) are named Sub-Elements and comprise as many hierarchical levels (Level 4 and below) as are deemed appropriate to the needs of that specific example.

The decision as to where among the classification elements to include specific construction items will rely on professional judgment as to where professionals in current practice normally look for such items.

Only items that impact the choice and cost of the bridge elements are included. Other civil works in the transportation system are not included. Consequently, the proposed classification does not include utilities - pipelines (water, natural gas, and petroleum) and transmission lines (electrical, communication, and video)—sharing the same right of way as the transportation system.

Elements, as used and defined in the UNIFORMAT II family of classifications, will ideally display the following additional attributes:

Capable of being defined precisely;

Self-explanatory;

Separable at all stages of development;

Quantifiable at all stages of development;

Capable of reconciliation with other elemental classifications;

Allow comparisons, project to project, in a meaningful way;

Is a functional component of the constructed entity.

Sitework elements are provided in the proposed classification for exclusive use in support of the construction of bridges, not to classify elements of major civil construction works. Sitework elements presented in Table 2.2 are designed to provide sufficient detail to planners so they will not need to resort to other elemental classifications when working on a bridge project.

\subsection{Description of Proposed UNIFORMAT II Bridge Elements}

Table 2.3 provides, for each Level 3 Individual Element, the name, functions, description, inclusions, exclusions, and unit of measure. The table uses the framework outlined in the UNIFORMAT II Guidelines document. ${ }^{37}$ The goal of that framework is to briefly, yet concisely, summarize the important features of each element. As a complement to the material presented in this section, this report includes Appendix B and Appendix $\mathrm{C}$ to facilitate the use of the proposed UNIFORMAT II classification of bridge elements.

${ }^{37}$ ASTM International. "Guidelines for Developing UNIFORMAT II Standard Classifications,” op cit. 
Appendix B is designed as an illustrated guide to the proposed UNIFORMAT II classification of bridge elements. The appendix includes diagrams, engineering drawings, and, where appropriate, photographs to identify the appearance of each element and how it fits into the overall framework.

Appendix $\mathrm{C}$ uses a case study bridge construction project to demonstrate how to use the proposed UNIFORMAT II classification and sub-classifications to analyze and manage bridge design and construction costs. The case study bridge is a single-span, modified tied-arch carrying Interstate 94 (I-94) over Telegraph Road in Taylor, Michigan. This bridge was part of the reconstruction of I-94 for the Super Bowl XL game held in 2006.

The functions are classified as Primary, Secondary, and Tertiary. All three levels of functions may be served. However, one or two functions may be the driving force behind the existence of the element, and they are classified as Primary functions.

The element descriptions provide an understanding of the purpose and application of the element. The narrative is intended to provide a brief synopsis of the key features which serve to define the element.

The purpose of the element inclusions is to list features that make up the element.

The purpose of the element exclusions is to list features that are not included in the element but which are included elsewhere in the proposed classification. Because this classification refers solely to permanent physical parts of bridge constructions, references to construction enabling (cranes and formwork), temporary construction (cofferdams and traffic detours), and risk mitigation (allowances and contingencies) cost figures are omitted from the element exclusions. ${ }^{38}$

The purpose of the unit of measure is to provide a means for calculating the magnitude, or size, of each element in any bridge description; units of measure are important to all users of elemental classifications. Units of measure are of prime importance in the elemental cost management process. Both SI and Customary units are reported. SI units are reported first followed by Customary units within parentheses. Table 2.3 uses the following unit of measure abbreviations: linear meters $(\mathrm{m})$ and linear feet $(\mathrm{ft})$; square meters $\left(\mathrm{m}^{2}\right)$ and square feet $\left(\mathrm{ft}^{2}\right)$; cubic meters $\left(\mathrm{m}^{3}\right)$ and cubic yards $\left(\mathrm{yd}^{3}\right)$; and kilograms (kg) and pounds (lb).

\footnotetext{
${ }^{38}$ Appendix $\mathrm{C}$ provides for the inclusion of construction enabling, temporary, and risk mitigation cost figures. Two tables are used to introduce costs related to program management (field requirements and office overhead and profit) and risk management (allowances, contingencies, and reserve sums). Cost data for the Telegraph Road bridge are then tabulated and analyzed using the two tables referenced above and the proposed classification presented in this section and the sub-classifications presented in Appendix A.
} 
Table 2.3 Description of Proposed UNIFORMAT II Bridge Elements

\begin{tabular}{|c|c|}
\hline A SUBSTRUCTURE & \\
\hline \multicolumn{2}{|l|}{ A10 Piers } \\
\hline \multicolumn{2}{|r|}{ A1010 Foundations } \\
\hline Primary Function & Transfer load, Minimize settlement \\
\hline Secondary Function & Minimize maintenance \\
\hline Tertiary Function & Facilitate construction \\
\hline Description & $\begin{array}{l}\text { Foundations are structures that transfer the load of the bridge } \\
\text { substructures to the ground. They may be spread footings, piles, or } \\
\text { drilled shafts. The type depends upon the soil conditions. }\end{array}$ \\
\hline Includes & Excavation and backfilling \\
\hline Excludes & \\
\hline Unit of Measure & $\mathrm{m}^{3}\left(\mathrm{yd}^{3}\right)$ or $\mathrm{m}(\mathrm{ft})$ \\
\hline \multicolumn{2}{|r|}{ A1020 Walls } \\
\hline Primary Function & Distribute load, Protect foundation \\
\hline Secondary Function & Enhance appearance \\
\hline Tertiary Function & Expedite construction \\
\hline Description & $\begin{array}{l}\text { Walls are structures that support and brace the columns; in addition } \\
\text { to transferring the load from the columns to the foundation, they } \\
\text { protect the pier against impacts from vehicles, vessels, and debris. }\end{array}$ \\
\hline Includes & Any struts to brace columns \\
\hline Excludes & \\
\hline Unit of Measure & $\mathrm{m}^{3}\left(\mathrm{yd}^{3}\right)$ or $\mathrm{kg}(\mathrm{lb})$ \\
\hline \multicolumn{2}{|r|}{ A1030 Columns } \\
\hline Primary Function & Distribute load \\
\hline Secondary Function & Enhance appearance \\
\hline Tertiary Function & Expedite construction \\
\hline Description & $\begin{array}{l}\text { Columns are structures that support the cap beam and transfer the } \\
\text { load from the cap beam to the wall below. }\end{array}$ \\
\hline \multicolumn{2}{|l|}{ Includes } \\
\hline Excludes & \\
\hline Unit of Measure & $\mathrm{m}^{3}\left(\mathrm{yd}^{3}\right)$ or $\mathrm{kg}(\mathrm{lb})$ \\
\hline
\end{tabular}




\begin{tabular}{|l|l|}
\hline \multicolumn{2}{|c|}{ A1040 Cap Beams } \\
\hline Primary Function & Distribute load \\
\hline Secondary Function & Enhance appearance \\
\hline Tertiary Function & Expedite construction \\
\hline Description & $\begin{array}{l}\text { Cap beams are structures that receive and transfer beam loads from } \\
\text { the deck to the bridge columns. }\end{array}$ \\
\hline Includes & Bridge seat \\
\hline Excludes & Bearings and anchor bolts (see Bearings, Flexural Members) \\
\hline Unit of Measure & $\mathrm{m}^{3}\left(\mathrm{yd}^{3}\right)$ or $\mathrm{kg}(\mathrm{lb})$ \\
\hline
\end{tabular}

\begin{tabular}{|c|c|}
\hline A SUBSTRUCTURE & \\
\hline A20 Towers & \\
\hline \multicolumn{2}{|r|}{ A2010 Foundations } \\
\hline Primary Function & Transfer load, Minimize settlement \\
\hline Secondary Function & Minimize maintenance \\
\hline Tertiary Function & Facilitate construction \\
\hline Description & $\begin{array}{l}\text { Foundations are structures that transfer the load of the bridge } \\
\text { substructures to the ground. They may be spread footings, piles, or } \\
\text { drilled shafts. The type depends upon the soil conditions. }\end{array}$ \\
\hline Includes & Excavation and backfilling \\
\hline \multicolumn{2}{|l|}{ Excludes } \\
\hline Unit of Measure & $\mathrm{m}^{3}\left(\mathrm{yd}^{3}\right)$ or $\mathrm{m}(\mathrm{ft})$ \\
\hline
\end{tabular}

\begin{tabular}{|l|l|}
\hline \multicolumn{2}{|c|}{ A2020 Walls } \\
\hline Primary Function & Distribute load, Protect foundation \\
\hline Secondary Function & Enhance appearance \\
\hline Tertiary Function & Expedite construction \\
\hline Description & $\begin{array}{l}\text { Walls are structures that support and brace the columns; in addition } \\
\text { to transferring the load from the columns to the foundation, they } \\
\text { protect the pier against impacts from vehicles, vessels, and debris. }\end{array}$ \\
\hline Includes & Any struts to brace columns \\
\hline Excludes & \\
\hline Unit of Measure & $\mathrm{m}^{3}\left(\mathrm{yd}^{3}\right)$ or $\mathrm{kg}(\mathrm{lb})$ \\
\hline
\end{tabular}




\begin{tabular}{|l|l|}
\hline \multicolumn{2}{|l|}{ A2030 Columns } \\
\hline Primary Function & Distribute load \\
\hline Secondary Function & Enhance appearance \\
\hline Tertiary Function & Expedite construction \\
\hline Description & $\begin{array}{l}\text { Columns are structures that support the cap beam and transfer the } \\
\text { load from the cap beam to the wall below. }\end{array}$ \\
\hline Includes & \\
\hline Excludes & $\mathrm{m}^{3}\left(\mathrm{yd}^{3}\right)$ or $\mathrm{kg}(\mathrm{lb})$ \\
\hline Unit of Measure &
\end{tabular}

\begin{tabular}{|l|l|}
\hline \multicolumn{1}{|l|}{ A2040 Cap Beams } \\
\hline Primary Function & Distribute load \\
\hline Secondary Function & Enhance appearance \\
\hline Tertiary Function & Expedite construction \\
\hline Description & $\begin{array}{l}\text { Cap beams are structures that receive and transfer beam loads from } \\
\text { the deck to the bridge columns. }\end{array}$ \\
\hline Includes & Bridge seat \\
\hline Excludes & Bearings and anchor bolts (see Bearings, Flexural Members) \\
\hline Unit of Measure & $\mathrm{m}^{3}\left(\mathrm{yd}^{3}\right)$ or kg (lb) \\
\hline
\end{tabular}

\section{A SUBSTRUCTURE}

A30 Abutments

\section{A3010 Foundations}

\begin{tabular}{|l|l|}
\hline Primary Function & Transfer load, Minimize settlement \\
\hline Secondary Function & Minimize maintenance \\
\hline Tertiary Function & Facilitate construction \\
\hline Description & $\begin{array}{l}\text { Foundations are structures that transfer the load of the bridge } \\
\text { substructures to the ground. They may be spread footings, piles, or } \\
\text { drilled shafts. The type depends upon the soil conditions. }\end{array}$ \\
\hline Includes & Excavation and backfilling \\
\hline Excludes & $\mathrm{m}^{3}\left(\mathrm{yd}^{3}\right)$ or $\mathrm{m}(\mathrm{ft})$ \\
\hline Unit of Measure &
\end{tabular}




\begin{tabular}{|c|c|}
\hline \multicolumn{2}{|r|}{ A3020 Stems } \\
\hline Primary Function & Distribute load, Retain earth \\
\hline Secondary Function & Minimize erosion \\
\hline Tertiary Function & Minimize settlement \\
\hline Description & $\begin{array}{l}\text { Stems are usually supported on piles; they partially or fully retain } \\
\text { earth behind, support the ends of the first and last spans of the } \\
\text { bridge, and support the approach slab. }\end{array}$ \\
\hline Includes & Bridge seat, reinforcing, concrete, and finishing \\
\hline Excludes & $\begin{array}{l}\text { Slope wall, foundation, drainage, and anchor bolts and bearings (see } \\
\text { Foundations, Drainage Systems, Slope Wall, Bearings) }\end{array}$ \\
\hline Unit of Measure & $\mathrm{m}^{3}\left(\mathrm{yd}^{3}\right)$ or $\mathrm{kg}(\mathrm{lb})$ \\
\hline
\end{tabular}

\begin{tabular}{|c|c|}
\hline \multicolumn{2}{|r|}{ A3030 Wing Walls } \\
\hline Primary Function & Retain earth \\
\hline Secondary Function & Minimize erosion \\
\hline Tertiary Function & Enhance appearance \\
\hline Description & $\begin{array}{l}\text { Wing walls (parallel, perpendicular, or angled) are structures } \\
\text { connected to the abutment and supported by piles that retain the } \\
\text { embankment below the approach road. }\end{array}$ \\
\hline Includes & Reinforcing, concrete, and finishing \\
\hline Excludes & Approach slab and parapet (see Approach Slab, Barriers) \\
\hline Unit of Measure & $\mathrm{m}^{3}\left(\mathrm{yd}^{3}\right)$ \\
\hline
\end{tabular}

\begin{tabular}{|c|}
\hline A SUBSTRUCTURE \\
\hline A40 Other Supports \\
\hline
\end{tabular}

\begin{tabular}{|c|c|}
\hline \multicolumn{2}{|r|}{ A4010 Thrust Blocks } \\
\hline Primary Function & Transfer load, Transfer thrust \\
\hline Secondary Function & Minimizes movement \\
\hline \multicolumn{2}{|l|}{ Tertiary Function } \\
\hline Description & $\begin{array}{l}\text { Thrust blocks are a special substructure of a true arch bridge that } \\
\text { receive loads from the ribs and transfer loads to the foundation. }\end{array}$ \\
\hline Includes & Structure excavation, reinforcing, concrete, and finishing \\
\hline Excludes & $\begin{array}{l}\text { Furnishing and installation of anchor bolts, bearing plates, utility } \\
\text { relocation (see Demolition and Relocation, Flexural Members) }\end{array}$ \\
\hline Unit of Measure & $\mathrm{m}^{3}\left(\mathrm{yd}^{3}\right)$ \\
\hline
\end{tabular}




\begin{tabular}{|l|l|}
\hline \multicolumn{2}{|l|}{ A4020 Anchorages } \\
\hline Primary Function & Secure cable, Transfer load \\
\hline Secondary Function & Maintain even distribution \\
\hline Tertiary Function & $\begin{array}{l}\text { Anchorages are a special substructure to which the weight of the } \\
\text { deck and supporting superstructure is secured via cables and steel } \\
\text { eye bars imbedded in solid rock or massive concrete blocks. }\end{array}$ \\
\hline Description & $\begin{array}{l}\text { Structure excavation, reinforcing, concrete, finishing, and cable } \\
\text { support (Steel Eye Bar) }\end{array}$ \\
\hline Includes & $\mathrm{m}^{3}\left(\mathrm{yd}^{3}\right)$ \\
\hline Excludes &
\end{tabular}

\section{B SUPERSTRUCTURE \\ B10 Short Span Assemblies}

\section{B1010 Flexural Members}

\begin{tabular}{|l|l|}
\hline Primary Function & Support Load \\
\hline Secondary Function & Minimize deflection \\
\hline Tertiary Function & Increase redundancy \\
\hline \multirow{2}{*}{ Description } & $\begin{array}{l}\text { Flexural members are commonly known as beams and girders that } \\
\text { support the bridge deck. When the depth of the girder is shallow, it } \\
\text { is referred to as a beam. }\end{array}$ \\
\hline Includes & $\begin{array}{l}\text { Fabrication and installation of beams, girders, shear connectors, } \\
\text { splices, connections, and stiffeners }\end{array}$ \\
\hline Excludes & $\begin{array}{l}\text { Diaphragms, bracings, bearings (see Diaphragms, Bracings, } \\
\text { Bearings })\end{array}$ \\
\hline Unit of Measure & kg (lb) or m $(\mathrm{ft})$ \\
\hline
\end{tabular}

\begin{tabular}{|l|l|}
\hline \multicolumn{2}{|c|}{ B1020 Diaphragms } \\
\hline Primary Function & Stabilize girder, Brace girders \\
\hline Secondary Function & Facilitate deck reconstruction \\
\hline Tertiary Function & \\
\hline Description & Diaphragms are braces for shallow-depth beams. \\
\hline Includes & \\
\hline Excludes & \\
\hline Unit of Measure & $\mathrm{kg}(\mathrm{lb}) \mathrm{or} \mathrm{m}^{3}\left(\mathrm{yd}^{3}\right)$ \\
\hline
\end{tabular}




\begin{tabular}{|c|c|}
\hline \multicolumn{2}{|r|}{ B1030 Bracings } \\
\hline Primary Function & Stabilize girders/ribs/truss members \\
\hline Secondary Function & Facilitate deck reconstruction \\
\hline Tertiary Function & \\
\hline Description & $\begin{array}{l}\text { Bracings are structural members used to brace deep-depth girders, } \\
\text { ribs, and truss members. }\end{array}$ \\
\hline Includes & Fabrication and erection of structural members \\
\hline Excludes & \\
\hline Unit of Measure & $\mathrm{kg}(\mathrm{lb})$ \\
\hline \multicolumn{2}{|r|}{ B1040 Bearings } \\
\hline Primary Function & Transfer load \\
\hline Secondary Function & Facilitate expansion and contraction \\
\hline Tertiary Function & Minimize maintenance \\
\hline Description & $\begin{array}{l}\text { Bearings are mechanical systems that transfer vertical and } \\
\text { longitudinal forces; expansion bearings allow rotational and } \\
\text { longitudinal movement. }\end{array}$ \\
\hline Includes & Fabrication and erection of bearings and anchor bolts \\
\hline Excludes & Bridge seat (see Cap Beams, Stems) \\
\hline Unit of Measure & $\mathrm{EACH}$ \\
\hline \multicolumn{2}{|l|}{ B SUPERSTRUCTURE } \\
\hline \multicolumn{2}{|l|}{$\begin{array}{l}\text { B20 Long Span } \\
\text { Assemblies }\end{array}$} \\
\hline \multicolumn{2}{|r|}{ B2010 Ribs } \\
\hline Primary Function & Transfer load \\
\hline Secondary Function & Facilitate inspection \\
\hline Tertiary Function & Enhance appearance \\
\hline Description & $\begin{array}{l}\text { Ribs are rectangular-, square-, or circular-shaped parts of the } \\
\text { superstructure for arch bridges; they receive loads from hangers and } \\
\text { spandrels and transfer them to the foundation. }\end{array}$ \\
\hline Includes & Splices, stiffeners, and special assemblies \\
\hline Excludes & Bracings, bearings (see Bracings, Bearings) \\
\hline Unit of Measure & $\operatorname{kg}(\mathrm{lb})$, or $\mathrm{m}^{3}\left(\mathrm{yd}^{3}\right)$, or $\mathrm{m}(\mathrm{ft})$ \\
\hline
\end{tabular}




\begin{tabular}{|c|c|}
\hline \multicolumn{2}{|r|}{ B2020 Cables } \\
\hline Primary Function & Transfer load \\
\hline Secondary Function & Enhance appearance \\
\hline \multicolumn{2}{|l|}{ Tertiary Function } \\
\hline Description & $\begin{array}{l}\text { Cables, made of steel wires bound together and draped over towers } \\
\text { to anchors at each cable end, receive through hangers the load from } \\
\text { the deck. }\end{array}$ \\
\hline Includes & Fabrication and installation of cables, cable support \\
\hline Excludes & Anchorage (see Anchorage) \\
\hline Unit of Measure & $\mathrm{m}(\mathrm{ft})$ \\
\hline \multicolumn{2}{|r|}{ B2030 Hangers } \\
\hline Primary Function & Transfer load \\
\hline Secondary Function & Ease replacement \\
\hline Tertiary Function & Enhance appearance \\
\hline Description & $\begin{array}{l}\text { Hangers are rods or strands that connect the deck to the ribs (arch } \\
\text { bridges) or the main cable (cable-stayed or suspension bridges); } \\
\text { they receive loads from the deck and transfer loads to the ribs or } \\
\text { main cable in tension. }\end{array}$ \\
\hline Includes & Splices (rod), strand assembly, protection \\
\hline Excludes & End connections (see Flexural Members and Ribs) \\
\hline Unit of Measure & $\mathrm{m}(\mathrm{ft})$ \\
\hline \multicolumn{2}{|r|}{ B2040 Spandrels } \\
\hline Primary Function & Transfer load \\
\hline Secondary Function & Ease replacement \\
\hline Tertiary Function & Enhance appearance \\
\hline Description & $\begin{array}{l}\text { Spandrels are concrete or steel members that connect the deck to } \\
\text { the ribs (arch bridges); they receive loads from the deck and } \\
\text { transfer loads to the ribs in compression. They are below the deck } \\
\text { and above the rib. }\end{array}$ \\
\hline Includes & Concrete or steel members, protection \\
\hline Excludes & End connections (see Flexural Members and Ribs) \\
\hline Unit of Measure & $\mathrm{m}(\mathrm{ft})$ \\
\hline
\end{tabular}




\begin{tabular}{|c|c|}
\hline \multicolumn{2}{|r|}{ B2050 Ties } \\
\hline Primary Function & Eliminate thrust \\
\hline \multicolumn{2}{|l|}{ Secondary Function } \\
\hline \multicolumn{2}{|l|}{ Tertiary Function } \\
\hline Description & $\begin{array}{l}\text { A tie is a horizontal tension member that connects the two ends of } \\
\text { the compression ribs of an arch bridge and balances the horizontal } \\
\text { thrust. }\end{array}$ \\
\hline Includes & $\begin{array}{l}\text { Fabrication and erection of structural steel, stiffeners, splices, and } \\
\text { other connections }\end{array}$ \\
\hline Excludes & $\begin{array}{l}\text { Hangers, spandrels, bearings (see Bearings, Hangers, and } \\
\text { Spandrels) }\end{array}$ \\
\hline Unit of Measure & $\mathrm{kg}(\mathrm{lb})$ \\
\hline \multicolumn{2}{|r|}{ B2060 Truss Members } \\
\hline Primary Function & Support load, Reduce weight \\
\hline Secondary Function & Minimize deflection \\
\hline \multicolumn{2}{|l|}{ Tertiary Function } \\
\hline Description & $\begin{array}{l}\text { Truss members, connected at nodes by plates, are two-dimensional } \\
\text { structures that support the superstructure. }\end{array}$ \\
\hline Includes & Splices and other connections \\
\hline Excludes & Bracings, bearings (see Bracings, Bearings) \\
\hline Unit of Measure & $\mathrm{kg}(\mathrm{lb})$, or $\mathrm{m}^{3}\left(\mathrm{yd}^{3}\right)$, or $\mathrm{m}(\mathrm{ft})$ \\
\hline \multicolumn{2}{|r|}{ B2070 Segmental Box Girders } \\
\hline Primary Function & Support Load \\
\hline Secondary Function & Minimize deflection \\
\hline Tertiary Function & Facilitate Construction \\
\hline Description & $\begin{array}{l}\text { Segmental box girders are concrete box sections with or without } \\
\text { overhanging flanges. The segments are precast sections which are } \\
\text { post tensioned in the field. }\end{array}$ \\
\hline Includes & Post tensioning \\
\hline Excludes & Bracings, bearings (see Bracings, Bearings) \\
\hline Unit of Measure & $\mathrm{m}(\mathrm{ft})$ \\
\hline
\end{tabular}




\begin{tabular}{|c|c|}
\hline B SUPERSTRUCTURE & \\
\hline B30 Deck & \\
\hline \multicolumn{2}{|r|}{ B3010 Structural Surface } \\
\hline Primary Function & Transfer load \\
\hline Secondary Function & Minimize maintenance \\
\hline Tertiary Function & Facilitate future expansion \\
\hline Description & The structural surface supports the wearing surface and traffic. \\
\hline Includes & Reinforcing, concrete, and finishing \\
\hline Excludes & $\begin{array}{l}\text { Expansion joint assembly, parapet, barriers (see Expansion Joints, } \\
\text { Barriers, Drainage) }\end{array}$ \\
\hline Unit of Measure & $\mathrm{m}^{3}\left(\mathrm{yd}^{3}\right)$ or EACH \\
\hline
\end{tabular}

\begin{tabular}{|l|l|}
\hline \multicolumn{2}{|c|}{ B3020 Wearing Surface } \\
\hline Primary Function & Protect structure, Guide traffic \\
\hline Secondary Function & Comfort riders \\
\hline Tertiary Function & Reduce maintenance \\
\hline Description & $\begin{array}{l}\text { The wearing surface is the part of the road or rail system that comes } \\
\text { into contact with the vehicle or train car wheels. }\end{array}$ \\
\hline Includes & Concrete or asphalt overlay or rails, striping, and marking \\
\hline Excludes & \\
\hline Unit of Measure & $\mathrm{m}^{2}\left(\mathrm{ft}^{2}\right)$ \\
\hline
\end{tabular}

\section{PROTECTION}

\section{C10 Structure Protection}

\begin{tabular}{|l|l|}
\multicolumn{1}{|l|}{ C1010 Slope Walls } \\
\hline Primary Function & Protect abutment \\
\hline Secondary Function & Prevent erosion \\
\hline Tertiary Function & Enhance appearance \\
\hline Description & $\begin{array}{l}\text { Slope walls, made of stone, concrete, gravel, or gravel with asphalt } \\
\text { mix, support the sloped surface and protect the bridge abutment. }\end{array}$ \\
\hline Includes & Reinforcing, concrete, and finishing \\
\hline Excludes & Excavation and backfill (see Earthwork) \\
\hline Unit of Measure & $\mathrm{m}^{2}\left(\mathrm{ft}^{2}\right)$ \\
\hline
\end{tabular}




\begin{tabular}{|l|l|}
\hline \multicolumn{2}{|c|}{ C1020 Expansion Joints } \\
\hline Primary Function & Facilitate expansion and contraction \\
\hline Secondary Function & Maintain smooth surface \\
\hline Tertiary Function & Facilitate replacement \\
\hline Description & $\begin{array}{l}\text { Expansion joints allow expansion and contraction of the slab while } \\
\text { keeping the substructure stationary. }\end{array}$ \\
\hline Includes & $\begin{array}{l}\text { Furnishing and installation of expansion joint support and } \\
\text { expansion joint }\end{array}$ \\
\hline Excludes & m (ft) \\
\hline Unit of Measure &
\end{tabular}

\begin{tabular}{|l|l|}
\hline \multicolumn{2}{|l|}{ C1030 Protective Coats } \\
\hline Primary Function & Protect structure \\
\hline Secondary Function & Minimize maintenance \\
\hline Tertiary Function & $\begin{array}{l}\text { Protective coats are paints, sealants, or preservatives that are } \\
\text { applied to concrete surfaces of the bridge. }\end{array}$ \\
\hline Description & Minor repair work, cleaning surface, and coating \\
\hline Includes & Major repair work to other bridge elements \\
\hline Excludes & $\mathrm{m}^{2}\left(\mathrm{ft}^{2}\right)$ \\
\hline Unit of Measure &
\end{tabular}

\begin{tabular}{|l|l|}
\hline \multicolumn{1}{|l|}{ C1040 Sacrificial Beams } \\
\hline Primary Function & Protect girders \\
\hline Secondary Function & Reduce maintenance \\
\hline Tertiary Function & $\begin{array}{l}\text { Sacrificial beams have a lower clearance than the main beams to } \\
\text { ensure that excessive-height vehicles will hit the sacrificial beam } \\
\text { before impacting the main beams. }\end{array}$ \\
\hline Description & $\begin{array}{l}\text { Fabrication and erection of structural steel, stiffeners, splices, and } \\
\text { other connections }\end{array}$ \\
\hline Includes & Bracings, bearings (see Bracings, Bearings) \\
\hline Excludes & kg (lb) \\
\hline Unit of Measure &
\end{tabular}




\begin{tabular}{|c|c|}
\hline \multicolumn{2}{|r|}{ C1050 Drainage Systems } \\
\hline Primary Function & Minimize erosion \\
\hline Secondary Function & Protect traffic \\
\hline Tertiary Function & Protect structure \\
\hline Description & $\begin{array}{l}\text { Drainage systems are scuppers to drain the bridge deck, downspouts } \\
\text { to carry off the water from the scuppers, and buried drains behind } \\
\text { abutments and adjacent to sleeper slabs. }\end{array}$ \\
\hline Includes & $\begin{array}{l}\text { Fabrication and installation of scuppers, drain tiles, drain pipes, and } \\
\text { related earthwork }\end{array}$ \\
\hline Excludes & Structural surface (see Structural Surface) \\
\hline Unit of Measure & $\mathrm{EACH}$ or $\mathrm{m}(\mathrm{ft})$ \\
\hline \multicolumn{2}{|c|}{ C1060 Inspection and Maintenance Systems } \\
\hline Primary Function & Facilitate inspection \\
\hline Secondary Function & Facilitate maintenance \\
\hline \multicolumn{2}{|l|}{ Tertiary Function } \\
\hline Description & $\begin{array}{l}\text { These systems include platforms, railings, stairways, and hoist ways } \\
\text { to facilitate inspection and maintenance. }\end{array}$ \\
\hline Includes & Handrails or other type of barriers \\
\hline \multicolumn{2}{|l|}{ Excludes } \\
\hline Unit of Measure & $\mathrm{m}^{2}\left(\mathrm{ft}^{2}\right)$ \\
\hline \multicolumn{2}{|l|}{ C PROTECTION } \\
\hline \multicolumn{2}{|l|}{ C20 Traffic Protection } \\
\hline \multicolumn{2}{|r|}{ C2010 Barriers } \\
\hline Primary Function & Separate traffic, Protect occupants \\
\hline Secondary Function & Protect structure \\
\hline Tertiary Function & Minimize maintenance \\
\hline Description & $\begin{array}{l}\text { Barriers are structures designed to: withstand forces due to crashes; } \\
\text { separate the opposing traffic; and protect bridge structures adjacent } \\
\text { to live traffic. }\end{array}$ \\
\hline Includes & Noise wall support, light pole support, traffic control support \\
\hline \multicolumn{2}{|l|}{ Excludes } \\
\hline Unit of Measure & $\mathrm{m}^{3}\left(\mathrm{yd}^{3}\right)$ \\
\hline
\end{tabular}




\begin{tabular}{|l|l|}
\hline \multicolumn{2}{|c|}{ C2020 Protective Shields } \\
\hline Primary Function & Protect traffic (below) \\
\hline Secondary Function & \\
\hline Tertiary Function & $\begin{array}{l}\text { Protective shields are barriers below the bridge deck to protect } \\
\text { traffic below from falling objects. }\end{array}$ \\
\hline Description & Membranes and supports designed to catch falling objects \\
\hline Includes & \\
\hline Excludes & $\mathrm{m}^{2}\left(\mathrm{ft}^{2}\right)$ \\
\hline Unit of Measure &
\end{tabular}

\begin{tabular}{|l|l|}
\hline \multicolumn{2}{|c|}{ C2030 Traffic Controls } \\
\hline Primary Function & Manage Traffic \\
\hline Secondary Function & \\
\hline Tertiary Function & \\
\hline Description & Traffic controls are an assembly of signals, supports, and conduits \\
\hline Includes & Power source and related items \\
\hline Excludes & Base Support (see Barriers) \\
\hline Unit of Measure & EACH \\
\hline
\end{tabular}

\section{PROTECTION}

\section{C30 Other Protection}

\begin{tabular}{|l|l|}
\hline \multicolumn{1}{|l|}{ C3010 Lighting } \\
\hline Primary Function & Protect traffic \\
\hline Secondary Function & Guide traffic \\
\hline Tertiary Function & Discourage vandalism \\
\hline Description & $\begin{array}{l}\text { Lighting is illumination from fixtures that provide vehicle traffic } \\
\text { direction, ship navigation direction, task lighting, and vandalism } \\
\text { discouragement. }\end{array}$ \\
\hline Includes & Fabrication and installation of mast, lights, base plates, and power \\
\hline Excludes & Base support (see Barriers) \\
\hline Unit of Measure & EACH \\
\hline
\end{tabular}




\begin{tabular}{|l|l|}
\hline \multicolumn{2}{|c|}{ C3020 Signage } \\
\hline Primary Function & Guide traffic \\
\hline Secondary Function & Simplify or consolidate message \\
\hline Tertiary Function & $\begin{array}{l}\text { Signage is the provision of information through electronic or } \\
\text { printed message boards. }\end{array}$ \\
\hline Description & Fabrication and installation of sign and support, and power \\
\hline Includes & EACH \\
\hline Excludes & Unit of Measure \\
\hline
\end{tabular}

\begin{tabular}{|l|l|}
\hline \multicolumn{1}{|l|}{ C3030 Sound Barrier Walls } \\
\hline Primary Function & Abate traffic noise \\
\hline Secondary Function & Create visual barrier \\
\hline Tertiary Function & Enhance appearance \\
\hline Description & $\begin{array}{l}\text { A sound barrier wall is a structure to mask traffic noise from the } \\
\text { surrounding neighborhood. }\end{array}$ \\
\hline Includes & Wall panel, support, and connection to barrier \\
\hline Excludes & Base (see Barriers) \\
\hline Unit of Measure & $\mathrm{m}^{2}\left(\mathrm{ft}^{2}\right)$ \\
\hline
\end{tabular}

\begin{tabular}{|l|l|}
\hline \multicolumn{2}{|l|}{ C3040 Air Pressure Barriers } \\
\hline Primary Function & Protect people \\
\hline Secondary Function & Protect property \\
\hline Tertiary Function & $\begin{array}{l}\text { Air pressure barriers are structures to mitigate the impact of } \\
\text { significant air pressure differentials created by the passing of high } \\
\text { speed transportation vehicles. }\end{array}$ \\
\hline Description & $\begin{array}{l}\text { Barriers mounted on bridges to mitigate the impact of air pressure } \\
\text { differentials. }\end{array}$ \\
\hline Includes & Base (see Barriers) \\
\hline Excludes & $\mathrm{m}^{2}\left(\mathrm{ft}^{2}\right)$ \\
\hline Unit of Measure &
\end{tabular}




\begin{tabular}{|c|c|}
\hline \multicolumn{2}{|r|}{ C3050 Enclosure } \\
\hline Primary Function & Protect pedestrians and protect traffic \\
\hline Secondary Function & Facilitate maintenance \\
\hline Tertiary Function & Enhance appearance \\
\hline Description & $\begin{array}{l}\text { An enclosure is a vertical envelope with roof to protect pedestrians } \\
\text { and traffic crossing over a bridge. }\end{array}$ \\
\hline Includes & $\begin{array}{l}\text { Structural and architectural members to contain pedestrians and } \\
\text { traffic. }\end{array}$ \\
\hline \multicolumn{2}{|l|}{ Excludes } \\
\hline Unit of Measure & $\mathrm{m}^{2}\left(\mathrm{ft}^{2}\right)$ \\
\hline \multicolumn{2}{|l|}{ D SITEWORK } \\
\hline \multicolumn{2}{|l|}{ D10 Site Preparation } \\
\hline \multicolumn{2}{|r|}{ D1010 Clearing and Grubbing } \\
\hline Primary Function & Eliminate obstacles \\
\hline Secondary Function & Create staging area \\
\hline Tertiary Function & Provide temporary drainage \\
\hline Description & $\begin{array}{l}\text { Clearing is the removal from the construction site of trees and } \\
\text { abandoned utilities, and the grading and leveling of the site. } \\
\text { Grubbing is the removal of stumps and tree roots. }\end{array}$ \\
\hline Includes & Tree removal, abandoned utilities, minor earthwork \\
\hline Excludes & $\begin{array}{l}\text { Major earth work and major utility removal (see Demolition and } \\
\text { Relocation, Earthwork) }\end{array}$ \\
\hline Unit of Measure & EACH or Hectare (Acre) \\
\hline \multicolumn{2}{|r|}{ D1020 Demolition and Relocation } \\
\hline Primary Function & Eliminate obstacles \\
\hline Secondary Function & Protect structures \\
\hline Tertiary Function & Protect environment \\
\hline Description & $\begin{array}{l}\text { Demolition is the complete or partial (e.g., deck or superstructure) } \\
\text { removal of an existing bridge, carried out on the whole bridge at } \\
\text { once or by removing a portion of the deck or superstructure in } \\
\text { stages to maintain traffic; relocation is the removal and } \\
\text { reinstallation of utilities. }\end{array}$ \\
\hline Includes & $\begin{array}{l}\text { Removal of bridge elements and disposal, relocation of utilities } \\
\text { such as storm sewer }\end{array}$ \\
\hline \multicolumn{2}{|l|}{ Excludes } \\
\hline Unit of Measure & $\mathrm{EACH}$ \\
\hline
\end{tabular}




\begin{tabular}{|c|c|}
\hline \multicolumn{2}{|r|}{ D1030 Earthwork } \\
\hline Primary Function & Prepare grade \\
\hline Secondary Function & Protect structures \\
\hline Tertiary Function & Protect environment \\
\hline Description & $\begin{array}{l}\text { Earthwork is excavation, placement, and compaction of material to } \\
\text { raise the bridge profile (material is hauled in and compacted) and to } \\
\text { lower the bridge profile (material is excavated and hauled away). }\end{array}$ \\
\hline Includes & $\begin{array}{l}\text { Shrinkage factor for embankment, hauling material to or from the } \\
\text { site }\end{array}$ \\
\hline Excludes & $\begin{array}{l}\text { Removal of hazardous material, structure excavation and back fill } \\
\text { (see Demolition and Relocation, Foundations) }\end{array}$ \\
\hline Unit of Measure & $\mathrm{m}^{3}\left(\mathrm{yd}^{3}\right)$ \\
\hline
\end{tabular}

\begin{tabular}{|l|l|}
\hline \multicolumn{2}{|c|}{ D1040 Hazardous Material Handling } \\
\hline Primary Function & Protect environment \\
\hline Secondary Function & Dispose hazardous waste \\
\hline Tertiary Function & Protect workers \\
\hline Description & $\begin{array}{l}\text { Hazardous material handling is the discovery, excavation, recovery, } \\
\text { and disposal of hazardous materials. }\end{array}$ \\
\hline Includes & \begin{tabular}{l} 
Excavation and disposal of material \\
\hline Excludes
\end{tabular} \\
\hline Unit of Measure & $\mathrm{m}^{3}\left(\mathrm{yd}^{3}\right)$ \\
\hline
\end{tabular}

\begin{tabular}{|l|l|}
\hline \multicolumn{2}{|c|}{ D1050 } \\
\hline Environmental Restoration/Replacement \\
\hline Primary Function & Protect environment \\
\hline Secondary Function & \\
\hline Tertiary Function & $\begin{array}{l}\text { Environmental restoration/replacement is the activity of restoring or } \\
\text { replacing elements of the environment disturbed by construction. }\end{array}$ \\
\hline Description & Restoration or replacement of wetlands \\
\hline Includes & Hectare (Acre) \\
\hline Excludes &
\end{tabular}




\begin{tabular}{|c|c|}
\hline \multicolumn{2}{|l|}{ D SITEWORK } \\
\hline $\begin{array}{l}\text { D20 Approach } \\
\text { Construction }\end{array}$ & \\
\hline \multicolumn{2}{|r|}{ D2010 Approach Slabs } \\
\hline Primary Function & Provide transition \\
\hline Secondary Function & Minimize settlement effects \\
\hline Tertiary Function & Facilitate construction \\
\hline Description & $\begin{array}{l}\text { An approach slab, supported by the bridge abutment on one side } \\
\text { and a sleeper slab or soil on the other, provides a smooth transition } \\
\text { between the roadway and the bridge, and spans any settlement gap } \\
\text { between the abutment and the roadway. }\end{array}$ \\
\hline Includes & Concrete, reinforcing, and finishing \\
\hline Excludes & Barrier and wing wall (see Barriers, Wing Walls) \\
\hline Unit of Measure & $\mathrm{m}^{2}\left(\mathrm{ft}^{2}\right)$ \\
\hline
\end{tabular}

\begin{tabular}{|l|l|}
\hline \multicolumn{2}{|c|}{ D2020 Sleeper Slabs } \\
\hline Primary Function & Protect substructure \\
\hline Secondary Function & Exclude water \\
\hline Tertiary Function & Minimize maintenance \\
\hline Description & $\begin{array}{l}\text { Sleeper slabs are rectangular concrete foundations that support } \\
\text { approach slabs. }\end{array}$ \\
\hline Includes & Excavation and backfill, concrete, and reinforcing \\
\hline Excludes & $\mathrm{Approach}$ slab (see Approach Slabs) \\
\hline Unit of Measure & $\mathrm{m}^{3}\left(\mathrm{yd}^{3}\right)$ \\
\hline
\end{tabular}

\begin{tabular}{|c|c|}
\hline & D2030 Earth Retention Systems \\
\hline Primary Function & Retain embankment \\
\hline Secondary Function & Enhance appearance \\
\hline Tertiary Function & Facilitate construction \\
\hline Description & $\begin{array}{l}\text { Earth retention systems are designed to support embankments when } \\
\text { the grades are not uniform. }\end{array}$ \\
\hline Includes & Foundation, wall, and cap \\
\hline Excludes & Excavation and backfill (see Earthwork) \\
\hline Unit of Measure & $\mathrm{m}^{3}\left(\mathrm{yd}^{3}\right)$ or $\mathrm{m}^{2}\left(\mathrm{ft}^{2}\right)$ \\
\hline
\end{tabular}




\section{Summary and Recommendations for Further Research}

\subsection{Summary}

This report presents a proposed UNIFORMAT II classification of bridge elements. Elemental classifications differ from traditional product-related classifications because their core concept is an element that performs a given function, regardless of the design specification, construction method, or materials used. The proposed classification represents a major revision and restructuring of ASTM Standard Classification E 2103, a bridge-related standard classification first issued by ASTM in 2000. The original bridge classification, E 2103, differed from the UNIFORMAT II elemental classification hierarchy in several ways which limited its applicability. The major revisions to E 2103 described in this report will promote its relevance, understanding, and acceptance in the bridge industry. Once approved and reissued by ASTM, the UNIFORMAT II Standard Classification of Bridge Elements, E 2103, will provide the basis for a comprehensive data set of bridge-related costs that will enable public and private decision makers to choose more cost-effective solutions for the design and construction of new bridges and the maintenance and repair of existing bridges across the Nation.

A set of alphanumeric designators for the proposed bridge classification is included. Because many users are interested in constructing databases for use in cost analyses associated with project planning, design, construction, maintenance and repair, and condition assessment, alphanumeric designators provide the basis for compiling and organizing cost data.

This report also includes a proposed list of sub-elements for bridges. The UNIFORMAT II hierarchy consists of three levels: Level 1, Major Group Elements; Level 2, Group Elements; and Level 3, Individual Elements. Thus, the core concept of an element resides at Level 3. However, because elements are major components of a constructed entity, there is often ambiguity of what exactly is included in an Individual Element and what should be rightfully excluded from it. Because sub-elements can be tied into a work breakdown structure, they significantly enhance the usefulness of an elemental classification across all project participants throughout the lifecycle of bridges and other constructed entities.

\subsection{Recommendations for Further Research}

The background work for this report uncovered several additional areas of research that would be of value to government agencies, standards development organizations, designers and constructors of physical infrastructure projects, and other stakeholders concerned with the costs of designing and constructing new physical infrastructure and of maintaining and repairing existing physical infrastructure across the Nation. Specifically, four additional UNIFORMAT II classifications are proposed for development: (1) tunnels; (2) highways; (3) railroads; and (4) water treatment and distribution. Each of these proposed UNIFORMAT II classifications corresponds to a critical infrastructure 
need identified in the American Society of Civil Engineers Report Card for America's Infrastructure. ${ }^{39}$

${ }^{39}$ ASCE 2009 Report Card for America's Infrastructure, op cit. 


\section{References}

American Association of State Highway and Transportation Officials (AASHTO). 2008. Bridging the Gap. Washington, DC: American Association of State Highway and Transportation Officials.

American Society of Civil Engineers (ASCE). 2009. ASCE 2009 Report Card for America's Infrastructure. Reston, VA: American Society of Civil Engineers.

American Society of Civil Engineers (ASCE). 2009. Facts About Bridges. Reston, VA: American Society of Civil Engineers.

ASTM International. "Classification for Allowance, Contingency and Reserve Sums in Building Construction Estimating," E 2168, Annual Book of ASTM Standards: 2010, Vol. 4.12. West Conshohocken, PA: ASTM International.

ASTM International. "Classification for Bridge Elements and Related Approach Work," E 2103, Annual Book of ASTM Standards: 2010, Vol. 4.12. West Conshohocken, PA: ASTM International.

ASTM International. "Classification for Building Construction Field Requirements, and Office Overhead and Profit," E 2083, Annual Book of ASTM Standards: 2010, Vol. 4.11. West Conshohocken, PA: ASTM International.

ASTM International. "Classification for Building Elements and Related SiteworkUNIFORMAT II," E 1557, Annual Book of ASTM Standards: 2010, Vol. 4.11. West Conshohocken, PA: ASTM International.

ASTM International. "Classification for Cost Estimate Classification System,” E 2516, Annual Book of ASTM Standards: 2010, Vol. 4.12. West Conshohocken, PA: ASTM International.

ASTM International. “Guide for Developing a Cost-Effective Risk Mitigation Plan for New and Existing Constructed Facilities," E 2506, Annual Book of ASTM Standards: 2010, Vol. 4.12. West Conshohocken, PA: ASTM International.

ASTM International. "Guide for Selecting Techniques for Treating Uncertainty and Risk in the Economic Evaluation of Buildings and Building Systems," E 1369, Annual Book of ASTM Standards: 2010, Vol. 4.11. West Conshohocken, PA: ASTM International.

ASTM International. "Guidelines for Developing UNIFORMAT II Standard Classifications," Working Paper. West Conshohocken, PA: ASTM International.

ASTM International. "Practice for Constructing FAST Diagrams and Performing Function Analysis During Value Analysis Study," E 2013, Annual Book of ASTM Standards: 2010, Vol. 4.11. West Conshohocken, PA: ASTM International. 
ASTM International. "Practice for Job Productivity Measurement," E 2691, Annual Book of ASTM Standards: 2010, Vol. 4.12. West Conshohocken, PA: ASTM International.

ASTM International. "Practice for Measuring Benefit-to-Cost and Savings-to-Investment Ratios for Buildings and Building Systems," E 964, Annual Book of ASTM Standards: 2010, Vol. 4.11. West Conshohocken, PA: ASTM International.

ASTM International. "Practice for Measuring Cost Risk of Buildings and Building Systems," E 1946, Annual Book of ASTM Standards: 2010, Vol. 4.11. West Conshohocken, PA: ASTM International.

ASTM International. "Practice for Measuring Internal Rate of Return and Adjusted Internal Rate of Return for Investments in Buildings and Building Systems," E 1057, Annual Book of ASTM Standards: 2010, Vol. 4.11. West Conshohocken, PA: ASTM International.

ASTM International. "Practice for Measuring Life-Cycle Costs of Buildings and Building Systems," E 917, Annual Book of ASTM Standards: 2010, Vol. 4.11. West Conshohocken, PA: ASTM International.

ASTM International. "Practice for Measuring Net Benefits and Net Savings for Investments in Buildings and Building Systems," E 1074, Annual Book of ASTM Standards: 2010, Vol. 4.11. West Conshohocken, PA: ASTM International.

ASTM International. "Practice for Measuring Payback for Investments in Buildings and Building Systems," E 1121, Annual Book of ASTM Standards: 2010, Vol. 4.11. West Conshohocken, PA: ASTM International.

ASTM International. "Practice for Performing and Reporting Cost Analysis During the Design Phase of a Project," E 1804, Annual Book of ASTM Standards: 2010, Vol. 4.11. West Conshohocken, PA: ASTM International.

ASTM International. "Practice for Performing Value Analysis (VA) of Buildings and Building Systems," E 1699, Annual Book of ASTM Standards: 2010, Vol. 4.11. West Conshohocken, PA: ASTM International.

ASTM International. "Practice for Presentation Format of Elemental Cost Estimates, Summaries, and Analyses," E 2514, Annual Book of ASTM Standards: 2010, Vol. 4.12. West Conshohocken, PA: ASTM International.

Bowen, Brian, Charette, Robert P., and Marshall, Harold E. 1992. UNIFORMAT II: A Recommended Classification for Building Elements and Related Sitework, NIST Special Publication 841. Gaithersburg, MD: National Institute of Standards and Technology. 
Charette, Robert P., and Marshall, Harold E. 1999. UNIFORMAT II: Elemental Classification for Building Specifications, Cost Estimating, and Cost Analysis, NISTIR 6389. Gaithersburg, MD: National Institute of Standards and Technology.

Hanscomb Associates, Inc. 1975. Automated Cost Control and Estimating System. Washington, DC: General Services Administration.

Illinois Department of Transportation (IDOT). 2011. IDOT Bridge Standards. ${ }^{40}$ Springfield, IL: Illinois Department of Transportation.

Royal Institute of Chartered Surveyors (RICS). 1969. Standard Form of Cost Analysis. London, England: The Building Cost Information Service.

${ }^{40}$ Diagrams from the IDOT Bridge Standards document reproduced in this report were in effect on March 25, 2011; current IDOT Bridge Standards are available at: http://www.dot.il.gov/bridges/bscadd2.html. 


\section{Appendix A Suggested Sub-Classifications of Bridge Elements}

This appendix presents suggested sub-classifications of bridge elements. The subclassifications expand the Level 3 Individual Elements into their constituent parts. These constituent parts include a Level 4 for all Individual Elements and, where necessary, a Level 5 (i.e., subdivisions of Level 4).

The suggested sub-classifications are presented in Table A.1. Table A.1 is laid out in a six column format. The first column lists the Level 1 Major Group Elements. The second column lists the Level 2 Group Elements. The third column lists the Level 3 Individual Elements. The fourth column lists the Level 4 Sub-Elements associated with each Level 3 Individual Element. The fifth column lists any Level 5 Sub-Elements associated with a Level 4 Sub-Element. Where appropriate, the Level 5 Sub-Elements are listed in the normal chronological order of construction. The sixth column lists any Level 5 Field Requirements that are both significant in their cost and specific to a Level 4 Sub-Element (e.g., Formwork associated with Spread Footings).

Alphanumeric designators are included for all Level 4 Sub-Elements, Level 5 SubElements, and Level 5 Field Requirements. It is anticipated that the alphanumeric designators will be useful in structuring cost manuals and in recording construction, operating, and maintenance costs in computer databases.

The alphanumeric designators use the Level 3 Individual Element character string as their reference point. For example, the first Level 4 Sub-Element associated with the A1010 Foundations Level 3 Individual Element is A101010 Spread Footings. Additional Level 4 Sub-Elements associated with A1010 Foundations are: A101020 Piles and A101030 Drilled Shafts. For Level 5 Sub-Elements, the alphanumeric designator uses the Level 4 Sub-Element as their reference point. For example, the first Level 5 Sub-Element associated with the A101010 Spread Footings Level 4 Sub-Element is A10101010 Excavation. Additional Level 5 Sub-Elements associated with A101010 Spread Footings are: A10101020 Reinforcement; A10101030 Placement; and A10101040 Backfilling. Spread Footings have a significant field requirement associated with them due to Formwork. The alphanumeric designator for Field Requirements includes an X to tie it back to Table 1 in E 2083, Standard Classification for Building Construction Field Requirements and Office Overhead and Profit. For example, the Level 5 Field Requirement associated with the A101010 Spread Footings Level 4 Sub-Element is A101010X2 Formwork. If Spread Footings are installed in a waterway, a Cofferdam will be required before Excavation can commence. In this case, the Level 5 Field Requirement associated with the A101010 Spread Footings Level 4 Sub-Element is A101010X1 Cofferdam. 
Table A.1 Suggested Sub-Classifications of Bridge Elements

\begin{tabular}{|c|c|c|c|c|c|}
\hline $\begin{array}{c}\text { Level } 1 \\
\text { Major Group }\end{array}$ & $\begin{array}{c}\text { Level 2 } \\
\text { Group Elements }\end{array}$ & $\begin{array}{c}\text { Level } 3 \\
\text { Individual Elements }\end{array}$ & $\begin{array}{c}\text { Level } 4 \\
\text { Sub-Elements }\end{array}$ & $\begin{array}{c}\text { Level } 5 \\
\text { Sub-Elements }\end{array}$ & $\begin{array}{c}\text { Level 5 } \\
\text { Field Requirements }\end{array}$ \\
\hline \multirow[t]{23}{*}{ A Substructure } & \multirow[t]{23}{*}{ A10 Piers } & \multirow[t]{16}{*}{ A1010 Foundations } & \multirow[t]{6}{*}{ A101010 Spread Footings } & & A101010X1 \\
\hline & & & & A10101010 Excavation & \\
\hline & & & & & A101010X2 \\
\hline & & & & A10101020 Reinforcement & \\
\hline & & & & $\begin{array}{ll}\text { A10101030 } & \text { Placement }\end{array}$ & \\
\hline & & & & A10101040 Backfilling & \\
\hline & & & \multirow[t]{3}{*}{ A101020 Piles } & $\begin{array}{ll}\text { A10102010 } & \text { Test Piles }\end{array}$ & \\
\hline & & & & A10102020 Piles & \\
\hline & & & & A10102030 Pile Cap & \\
\hline & & & \multirow[t]{7}{*}{ A101030 Drilled Shafts } & & Temporary Casing \\
\hline & & & & $\begin{array}{ll}\text { A10103010 } & \begin{array}{l}\text { Permanent } \\
\text { Casing }\end{array} \\
\end{array}$ & \\
\hline & & & & A10103020 Rock Socket & \\
\hline & & & & A10103030 Bell & \\
\hline & & & & A10103040 Reinforcement & \\
\hline & & & & A10103050 Placement & \\
\hline & & & & A10103060 Cap & \\
\hline & & \multirow[t]{7}{*}{ A1020 Walls } & \multirow{5}{*}{$\begin{array}{ll}\text { A102010 } & \begin{array}{l}\text { Cast-in-Place } \\
\text { Concrete }\end{array}\end{array}$} & & A102010X1 \\
\hline & & & & A10201020 Reinforcement & \\
\hline & & & & $\begin{array}{ll}\text { A10201030 } & \text { Placement }\end{array}$ & \\
\hline & & & & $\begin{array}{ll}\text { A10201040 Finishing } \\
\end{array}$ & \\
\hline & & & & A10201050 Coating & \\
\hline & & & \multirow[t]{2}{*}{ A102020 Precast Concrete } & A10202010 Fabrication & \\
\hline & & & & A10202020 Erection & \\
\hline
\end{tabular}




\begin{tabular}{|c|c|c|c|c|c|}
\hline $\begin{array}{c}\text { Level } 1 \\
\text { Major Group } \\
\text { Elements } \\
\end{array}$ & $\begin{array}{c}\text { Level } 2 \\
\text { Group Elements }\end{array}$ & $\begin{array}{c}\text { Level 3 } \\
\text { Individual Elements }\end{array}$ & $\begin{array}{c}\text { Level } 4 \\
\text { Sub-Elements }\end{array}$ & $\begin{array}{c}\text { Level 5 } \\
\text { Sub-Elements }\end{array}$ & $\begin{array}{c}\text { Level } 5 \\
\text { Field Requirements }\end{array}$ \\
\hline & & A1030 Columns & A103010 Cast-in-Place & & A103010X1 Formwork \\
\hline & & & & A10301020 Reinforcement & \\
\hline & & & & A10301030 Placement & \\
\hline & & & & $\begin{array}{ll}\text { A10301040 } & \text { Finishing }\end{array}$ & \\
\hline & & & A103020 Precast Concrete & A10302010 Fabrication & \\
\hline & & & & A10302020 Erection & \\
\hline & & & A103030 Steel & A10303010 Fabrication & \\
\hline & & & & A10303020 Erection & \\
\hline & & & A103040 Timber & A10304010 Fabrication & \\
\hline & & & & A10304020 Erection & \\
\hline & & A1040 Cap Beams & A104010 Cast-in-Place & & A104010X1 \\
\hline & & & Concrete & A10401020 Reinforcement & \\
\hline & & & & A10401030 Placement & \\
\hline & & & & $\begin{array}{ll}\text { A10401040 } & \text { Finishing }\end{array}$ & \\
\hline & & & A104020 Precast Concrete & A10402010 Fabrication & \\
\hline & & & & A10402020 Erection & \\
\hline & & & A104030 Steel & A10403010 Fabrication & \\
\hline & & & & A10403020 Erection & \\
\hline & & & A104040 Timber & A10404010 Fabrication & \\
\hline & & & & A10404020 Erection & \\
\hline & A20 Towers & A2010 Foundations & A201010 Spread Footings & & A201010X1 \\
\hline & & & & A20101010 Excavation & \\
\hline & & & & & A201010X2 Formwork \\
\hline & & & & A20101020 Reinforcement & \\
\hline & & & & A20101030 Placement & \\
\hline & & & & A20101040 Backfilling & \\
\hline
\end{tabular}




\begin{tabular}{|c|c|c|c|c|c|}
\hline $\begin{array}{c}\text { Level } 1 \\
\text { Major Group } \\
\text { Elements } \\
\end{array}$ & $\begin{array}{c}\text { Level } 2 \\
\text { Group Elements }\end{array}$ & $\begin{array}{c}\text { Level } 3 \\
\text { Individual Elements }\end{array}$ & $\begin{array}{c}\text { Level } 4 \\
\text { Sub-Elements }\end{array}$ & $\begin{array}{c}\text { Level } 5 \\
\text { Sub-Elements }\end{array}$ & $\begin{array}{c}\text { Level 5 } \\
\text { Field Requirements }\end{array}$ \\
\hline & & & A201020 Pile Foundations & A20102010 Test Piles & \\
\hline & & & & A20102020 Piles & \\
\hline & & & & A20102030 Pile Cap & \\
\hline & & & A201030 Drilled Shafts & & Temporary Casing \\
\hline & & & & $\begin{array}{ll}\text { A20103010 } & \begin{array}{l}\text { Permanent } \\
\text { Casing }\end{array} \\
\end{array}$ & \\
\hline & & & & A20103020 Rock Socket & \\
\hline & & & & A20103030 Bell & \\
\hline & & & & Reinforcement & \\
\hline & & & & A20103050 Placement & \\
\hline & & & & A20103060 Cap & \\
\hline & & A2020 & A202010 Cast-in-Place & & A202010X1 \\
\hline & & & Concrete & A20201010 Reinforcement & \\
\hline & & & & A20201020 Placement & \\
\hline & & & & A20201030 Finishing & \\
\hline & & & & A20201040 Coating & \\
\hline & & & Precast Concrete & A20202010 Fabrication & \\
\hline & & & & A20202020 Erection & \\
\hline & & Columns & A203010 Cast-in-Place & & A203010X1 \\
\hline & & & Concrete & A20301010 Reinforcement & \\
\hline & & & & A20301020 Placement & \\
\hline & & & & A20301030 Finishing & \\
\hline & & & A203020 Precast Concrete & A20302010 Fabrication & \\
\hline & & & & A20302020 Erection & \\
\hline & & & A203030 Steel & A20303010 Fabrication & \\
\hline & & & & A20303020 Erection & \\
\hline & & & A203040 & $\begin{array}{ll}\text { A20304010 } & \text { Fabrication }\end{array}$ & \\
\hline
\end{tabular}




\begin{tabular}{|c|c|c|c|c|c|}
\hline $\begin{array}{c}\text { Level } 1 \\
\text { Major Group }\end{array}$ & $\begin{array}{c}\text { Level } 2 \\
\text { Group Elements }\end{array}$ & $\begin{array}{c}\text { Level } 3 \\
\text { Individual Elements }\end{array}$ & $\begin{array}{c}\text { Level } 4 \\
\text { Sub-Elements }\end{array}$ & $\begin{array}{c}\text { Level } 5 \\
\text { Sub-Elements }\end{array}$ & $\begin{array}{c}\text { Level } 5 \\
\text { Field Requirements }\end{array}$ \\
\hline & & & & A20304020 Erection & \\
\hline & & \multirow[t]{10}{*}{ A2040 Cap Beams } & \multirow{4}{*}{$\begin{array}{ll}\text { A204010 } & \begin{array}{l}\text { Cast-in-Place } \\
\text { Concrete }\end{array}\end{array}$} & & A204010X1 \\
\hline & & & & A20401010 Reinforcement & \\
\hline & & & & A20401020 Placement & \\
\hline & & & & A20401030 Finishing & \\
\hline & & & \multirow[t]{2}{*}{ A204020 Precast Concrete } & A20402010 Fabrication & \\
\hline & & & & A20402020 Erection & \\
\hline & & & \multirow[t]{2}{*}{ A204030 Steel } & A20403010 Fabrication & \\
\hline & & & & A20403020 Erection & \\
\hline & & & \multirow[t]{2}{*}{ A204040 Timber } & A20404010 Fabrication & \\
\hline & & & & A20404020 Erection & \\
\hline & \multirow[t]{15}{*}{ A30 Abutments } & \multirow[t]{15}{*}{ A3010 Foundations } & \multirow[t]{5}{*}{ A301010 Spread Footings } & A30101010 Excavation & \\
\hline & & & & & A301010X1 \\
\hline & & & & A30101020 Reinforcement & \\
\hline & & & & A30101030 Placement & \\
\hline & & & & A30101040 Backfilling & \\
\hline & & & \multirow[t]{3}{*}{ A301020 Piles } & A30102010 Test Piles & \\
\hline & & & & A30102020 Piles & \\
\hline & & & & A30102030 Pile Cap & \\
\hline & & & \multirow[t]{7}{*}{ A301030 Drilled Shafts } & & Temporary Casing \\
\hline & & & & $\begin{array}{ll}\text { A30103010 } & \begin{array}{l}\text { Permanent } \\
\text { Casing }\end{array} \\
\end{array}$ & \\
\hline & & & & Rock Socket & \\
\hline & & & & A30103030 Bell & \\
\hline & & & & Reinforcement & \\
\hline & & & & A30103050 Placement & \\
\hline & & & & A30103060 & \\
\hline
\end{tabular}




\begin{tabular}{|c|c|c|c|c|c|}
\hline $\begin{array}{c}\text { Level 1 } \\
\text { Major Group } \\
\text { Elements } \\
\end{array}$ & $\begin{array}{c}\text { Level } 2 \\
\text { Group Elements }\end{array}$ & $\begin{array}{c}\text { Level } 3 \\
\text { Individual Elements }\end{array}$ & $\begin{array}{c}\text { Level } 4 \\
\text { Sub-Elements }\end{array}$ & $\begin{array}{c}\text { Level } 5 \\
\text { Sub-Elements }\end{array}$ & $\begin{array}{c}\text { Level } 5 \\
\text { Field Requirements }\end{array}$ \\
\hline & & \multirow[t]{6}{*}{ A3020 Stems } & \multirow{4}{*}{$\begin{array}{ll}\text { A302010 } & \begin{array}{l}\text { Cast-in-Place } \\
\text { Concrete }\end{array}\end{array}$} & & A302010X1 \\
\hline & & & & Reinforcement & \\
\hline & & & & A30201020 Placement & \\
\hline & & & & A30201030 & \\
\hline & & & \multirow[t]{2}{*}{ A302020 Precast Concrete } & A30202010 Fabrication & \\
\hline & & & & A30202020 Erection & \\
\hline & & \multirow[t]{6}{*}{ A3030 Wing Walls } & \multirow{4}{*}{$\begin{array}{ll}\text { A303010 } & \begin{array}{l}\text { Cast-in-Place } \\
\text { Concrete }\end{array}\end{array}$} & & A303010X1 \\
\hline & & & & A30301010 Reinforcement & \\
\hline & & & & A30301020 Placement & \\
\hline & & & & A30301030 Finishing & \\
\hline & & & \multirow[t]{2}{*}{ A303020 Precast Concrete } & A30302010 Fabrication & \\
\hline & & & & A30302020 Erection & \\
\hline & \multirow{14}{*}{$\begin{array}{ll}\text { A40 } & \text { Other } \\
& \text { Supports }\end{array}$} & \multirow[t]{7}{*}{ A4010 Thrust Blocks } & \multirow[t]{4}{*}{ A401010 Cap } & & A401010X1 \\
\hline & & & & A40101010 Reinforcement & \\
\hline & & & & A40101020 Placement & \\
\hline & & & & A40101030 Finishing & \\
\hline & & & \multirow[t]{3}{*}{ A401020 Foundations } & A40102010 Spread Footings & \\
\hline & & & & A40102020 Piles & \\
\hline & & & & A40102030 Drilled Shafts & \\
\hline & & \multirow[t]{7}{*}{ A4020 Anchorage } & \multirow[t]{2}{*}{ A402010 Prestressed } & A40201010 Spray Saddle & \\
\hline & & & & A40201020 Anchor & \\
\hline & & & \multirow{3}{*}{$\begin{array}{ll}\text { A402020 } & \text { Cast-in-Place } \\
& \text { Concrete }\end{array}$} & & A402020X1 \\
\hline & & & & A40202010 Reinforcement & \\
\hline & & & & A40202020 & \\
\hline & & & \multirow[t]{2}{*}{ A402030 Foundations } & A40203010 Spread Footings & \\
\hline & & & & A40203020 Piles & \\
\hline
\end{tabular}




\begin{tabular}{|c|c|c|c|c|c|c|c|c|c|}
\hline \multirow{2}{*}{$\begin{array}{c}\text { Level } 1 \\
\text { Major Group } \\
\text { Elements } \\
\end{array}$} & \multicolumn{2}{|c|}{$\begin{array}{c}\text { Level } 2 \\
\text { Group Elements }\end{array}$} & \multicolumn{2}{|c|}{$\begin{array}{c}\text { Level } 3 \\
\text { Individual Elements }\end{array}$} & \multicolumn{2}{|c|}{$\begin{array}{c}\text { Level } 4 \\
\text { Sub-Elements }\end{array}$} & \multicolumn{2}{|c|}{$\begin{array}{c}\text { Level } 5 \\
\text { Sub-Elements }\end{array}$} & $\begin{array}{c}\text { Level } 5 \\
\text { Field Requirements }\end{array}$ \\
\hline & & & & & & & A40203030 & Drilled Shafts & \\
\hline \multirow[t]{24}{*}{ B Superstructure } & \multirow{24}{*}{\multicolumn{2}{|c|}{$\begin{array}{ll}\text { B10 } & \text { Short Span } \\
& \text { Assemblies }\end{array}$}} & \multirow{10}{*}{\multicolumn{2}{|c|}{$\begin{array}{ll}\text { B1010 } & \text { Flexural } \\
& \text { Members }\end{array}$}} & \multirow{4}{*}{\multicolumn{2}{|c|}{$\begin{array}{ll}\text { B101010 } & \begin{array}{l}\text { Cast-in-Place } \\
\text { Concrete }\end{array}\end{array}$}} & & & B101010X1 \\
\hline & & & & & & & B10101010 & Reinforcement & \\
\hline & & & & & & & B10101020 & Placement & \\
\hline & & & & & & & B10101030 & Finishing & \\
\hline & & & & & \multirow{2}{*}{\multicolumn{2}{|c|}{ B101020 Precast Concrete }} & B10102010 & Fabrication & \\
\hline & & & & & & & B10102020 & Erection & \\
\hline & & & & & \multirow{2}{*}{\multicolumn{2}{|c|}{ B101030 Steel }} & B10103010 & Fabrication & \\
\hline & & & & & & & B10103020 & Erection & \\
\hline & & & & & \multirow{2}{*}{\multicolumn{2}{|c|}{ B101040 Timber }} & B10104010 & Fabrication & \\
\hline & & & & & & & B10104020 & Erection & \\
\hline & & & \multirow{8}{*}{\multicolumn{2}{|c|}{ B1020 Diaphragms }} & \multirow{3}{*}{\multicolumn{2}{|c|}{$\begin{array}{ll}\text { B102010 } & \begin{array}{l}\text { Cast-In-Place } \\
\text { Concrete }\end{array}\end{array}$}} & & & B102010X1 \\
\hline & & & & & & & B10201010 & Reinforcement & \\
\hline & & & & & & & B10201020 & Placement & \\
\hline & & & & & \multirow{2}{*}{\multicolumn{2}{|c|}{ B102020 Precast Concrete }} & B10202010 & Fabrication & \\
\hline & & & & & & & B10202020 & Erection & \\
\hline & & & & & \multirow{2}{*}{\multicolumn{2}{|c|}{ B102030 Steel }} & B10203010 & Fabrication & \\
\hline & & & & & & & B10203020 & Erection & \\
\hline & & & & & B102040 & Timber & & & \\
\hline & & & \multirow{3}{*}{\multicolumn{2}{|c|}{ B1030 Bracings }} & \multirow{2}{*}{\multicolumn{2}{|c|}{ B103010 Steel }} & B10301010 & Fabrication & \\
\hline & & & & & & & B10301020 & Erection & \\
\hline & & & & & B103020 & Timber & & & \\
\hline & & & \multirow{3}{*}{\multicolumn{2}{|c|}{ B1040 Bearings }} & B104010 & Elastomeric & & & \\
\hline & & & & & B104020 & Sliding & & & \\
\hline & & & & & B104030 & Roller & & & \\
\hline
\end{tabular}




\begin{tabular}{|c|c|c|c|c|c|c|c|c|c|}
\hline $\begin{array}{c}\text { Level } 1 \\
\text { Major Group } \\
\text { Elements } \\
\end{array}$ & \multicolumn{2}{|c|}{$\begin{array}{c}\text { Level } 2 \\
\text { Group Elements }\end{array}$} & \multicolumn{2}{|c|}{$\begin{array}{c}\text { Level 3 } \\
\text { Individual Elements }\end{array}$} & \multicolumn{2}{|c|}{$\begin{array}{c}\text { Level } 4 \\
\text { Sub-Elements }\end{array}$} & \multicolumn{2}{|c|}{$\begin{array}{c}\text { Level } 5 \\
\text { Sub-Elements }\end{array}$} & $\begin{array}{c}\text { Level } 5 \\
\text { Field Requirements }\end{array}$ \\
\hline & \multirow{24}{*}{\multicolumn{2}{|c|}{$\begin{array}{ll}\text { B20 } & \text { Long Span } \\
& \text { Assemblies }\end{array}$}} & \multirow{7}{*}{\multicolumn{2}{|c|}{ B2010 Ribs }} & \multirow{3}{*}{\multicolumn{2}{|c|}{$\begin{array}{ll}\text { B201010 } & \begin{array}{l}\text { Cast-in-Place } \\
\text { Concrete }\end{array}\end{array}$}} & & & B201010X1 Formwork \\
\hline & & & & & & & B20101010 & Reinforcement & \\
\hline & & & & & & & B20101020 & Placement & \\
\hline & & & & & \multirow{2}{*}{\multicolumn{2}{|c|}{ B201020 Precast Concrete }} & B20102010 & Fabrication & \\
\hline & & & & & & & B20102020 & Erection & \\
\hline & & & & & \multirow{2}{*}{\multicolumn{2}{|c|}{ B201030 Steel }} & B20103010 & Fabrication & \\
\hline & & & & & & & B20103020 & Erection & \\
\hline & & & \multirow{6}{*}{\multicolumn{2}{|c|}{ B2020 Cables }} & B202010 & Wires & & & \\
\hline & & & & & B202020 & Sockets & & & \\
\hline & & & & & B202030 & Saddles & & & \\
\hline & & & & & B202040 & Housings & & & \\
\hline & & & & & B202050 & Strands & & & \\
\hline & & & & & B202060 & Anchor Sockets & & & \\
\hline & & & \multirow{5}{*}{\multicolumn{2}{|c|}{ B2030 Hangers }} & B203010 & $\begin{array}{l}\text { Top Anchor } \\
\text { Socket }\end{array}$ & & & \\
\hline & & & & & B203020 & Strand & & & \\
\hline & & & & & B203030 & Boot & & & \\
\hline & & & & & B203040 & Spacer & & & \\
\hline & & & & & B203050 & $\begin{array}{l}\text { Bottom Anchor } \\
\text { Socket }\end{array}$ & & & \\
\hline & & & \multirow{6}{*}{\multicolumn{2}{|c|}{ B2040 Spandrels }} & \multirow{4}{*}{\multicolumn{2}{|c|}{$\begin{array}{ll}\text { B204010 } & \begin{array}{l}\text { Cast-in-Place } \\
\text { Concrete }\end{array}\end{array}$}} & & & B204010X1 \\
\hline & & & & & & & B20401010 & Reinforcement & \\
\hline & & & & & & & B20401020 & Placement & \\
\hline & & & & & & & B20401030 & Finishing & \\
\hline & & & & & \multirow{2}{*}{\multicolumn{2}{|c|}{ B204020 Precast Concrete }} & B20402010 & Fabrication & \\
\hline & & & & & & & B20402020 & Erection & \\
\hline
\end{tabular}




\begin{tabular}{|c|c|c|c|c|c|c|c|c|}
\hline \multirow{2}{*}{$\begin{array}{c}\text { Level } 1 \\
\text { Major Group } \\
\text { Elements } \\
\end{array}$} & $\begin{array}{c}\text { Level } 2 \\
\text { Group Elements }\end{array}$ & \multicolumn{2}{|c|}{$\begin{array}{c}\text { Level 3 } \\
\text { Individual Elements }\end{array}$} & \multicolumn{2}{|c|}{$\begin{array}{c}\text { Level } 4 \\
\text { Sub-Elements }\end{array}$} & \multicolumn{2}{|c|}{$\begin{array}{c}\text { Level } 5 \\
\text { Sub-Elements }\end{array}$} & $\begin{array}{c}\text { Level 5 } \\
\text { Field Requirements }\end{array}$ \\
\hline & & & & \multirow{2}{*}{\multicolumn{2}{|c|}{ B204030 Steel }} & B20403010 & Fabrication & \\
\hline & & & & & & B20403020 & Erection & \\
\hline & & \multirow{9}{*}{\multicolumn{2}{|c|}{ B2050 Ties }} & \multirow{3}{*}{\multicolumn{2}{|c|}{$\begin{array}{ll}\text { B205010 } & \begin{array}{l}\text { Cast-in-Place } \\
\text { Concrete }\end{array}\end{array}$}} & & & B205010X1 \\
\hline & & & & & & B20501010 & Reinforcement & \\
\hline & & & & & & B20501020 & Placement & \\
\hline & & & & \multirow{2}{*}{\multicolumn{2}{|c|}{ B205020 Precast Concrete }} & B20502010 & Fabrication & \\
\hline & & & & & & B20502020 & Erection & \\
\hline & & & & \multirow{2}{*}{\multicolumn{2}{|c|}{ B205030 Steel }} & B20503010 & Fabrication & \\
\hline & & & & & & B20503020 & Erection & \\
\hline & & & & B205040 & Splices & & & \\
\hline & & & & B205050 & Connections & & & \\
\hline & & \multirow{3}{*}{\multicolumn{2}{|c|}{ B2060 Truss members }} & B206010 & Members & & & \\
\hline & & & & B206020 & Splices & & & \\
\hline & & & & B206030 & Connections & & & \\
\hline & & \multirow{6}{*}{\multicolumn{2}{|c|}{$\begin{array}{ll}\text { B2070 } & \begin{array}{l}\text { Segmental Box } \\
\text { Girders }\end{array}\end{array}$}} & B207010 & Main Members & & & \\
\hline & & & & \multirow{5}{*}{\multicolumn{2}{|c|}{ B207020 Placement }} & B20702010 & Erection & \\
\hline & & & & & & & & Temporary Support \\
\hline & & & & & & & & $\begin{array}{l}\text { Temporary Post } \\
\text { Tensioning }\end{array}$ \\
\hline & & & & & & B20702020 & $\begin{array}{l}\text { Permanent Post } \\
\text { Tensioning }\end{array}$ & \\
\hline & & & & & & B20702030 & $\begin{array}{l}\text { Closure Piece } \\
\text { Placement }\end{array}$ & \\
\hline
\end{tabular}




\begin{tabular}{|c|c|c|c|c|c|c|}
\hline $\begin{array}{c}\text { Level } 1 \\
\text { Major Group }\end{array}$ & $\begin{array}{c}\text { Level 2 } \\
\text { Group Elements }\end{array}$ & \multicolumn{2}{|c|}{$\begin{array}{c}\text { Level 3 } \\
\text { Individual Elements }\end{array}$} & $\begin{array}{c}\text { Level } 4 \\
\text { Sub-Elements }\end{array}$ & $\begin{array}{c}\text { Level } 5 \\
\text { Sub-Elements }\end{array}$ & $\begin{array}{c}\text { Level 5 } \\
\text { Field Requirements }\end{array}$ \\
\hline & \multirow[t]{15}{*}{ B30 Deck } & \multirow{10}{*}{\multicolumn{2}{|c|}{$\begin{array}{ll}\text { B3010 } & \begin{array}{l}\text { Structural } \\
\text { Surface }\end{array} \\
\end{array}$}} & \multirow{4}{*}{$\begin{array}{ll}\text { B301010 } & \begin{array}{l}\text { Cast-in-Place } \\
\text { Concrete }\end{array}\end{array}$} & & B301010X1 Formwork \\
\hline & & & & & B30101010 Reinforcement & \\
\hline & & & & & B30101020 Placement & \\
\hline & & & & & $\begin{array}{ll}\text { B30101030 } & \text { Finishing }\end{array}$ & \\
\hline & & & & \multirow[t]{2}{*}{ B301020 Precast Concrete } & B30102010 Fabrication & \\
\hline & & & & & $\begin{array}{ll}\text { B30102020 } & \text { Erection }\end{array}$ & \\
\hline & & & & \multirow[t]{2}{*}{ B301030 Steel } & B30103010 Metal Deck & \\
\hline & & & & & B30103020 Connections & \\
\hline & & & & \multirow[t]{2}{*}{ B301040 Timber } & B30104010 Plank & \\
\hline & & & & & B30104020 Connections & \\
\hline & & \multirow[t]{5}{*}{ B3020 } & \multirow{5}{*}{$\begin{array}{l}\text { Wearing } \\
\text { Surface }\end{array}$} & \multirow{2}{*}{$\begin{array}{ll}\text { B302010 } & \begin{array}{l}\text { Cast-in-Place } \\
\text { Concrete }\end{array}\end{array}$} & B30201010 Placement & \\
\hline & & & & & B30201020 Finishing & \\
\hline & & & & \multirow[t]{2}{*}{ B302020 Asphalt } & B30202010 Placement & \\
\hline & & & & & B30202020 Finishing & \\
\hline & & & & B302030 Rails & & \\
\hline \multirow[t]{11}{*}{ C Protection } & \multirow{11}{*}{$\begin{array}{ll}\text { C10 } & \text { Structure } \\
& \text { Protection }\end{array}$} & \multirow{6}{*}{\multicolumn{2}{|c|}{ C1010 Slope Walls }} & \multirow{3}{*}{$\begin{array}{ll}\text { C101010 } & \begin{array}{l}\text { Cast-in-Place } \\
\text { Concrete }\end{array}\end{array}$} & C10101010 Reinforcement & \\
\hline & & & & & C10101020 Placement & \\
\hline & & & & & C10101030 Finishing & \\
\hline & & & & \multirow[t]{2}{*}{ C101020 Asphalt } & $\begin{array}{ll}\text { C10102010 } & \text { Gravel }\end{array}$ & \\
\hline & & & & & $\begin{array}{ll}\text { C10102020 } & \text { Placement }\end{array}$ & \\
\hline & & & & C101030 Stone & & \\
\hline & & \multirow[t]{3}{*}{$\mathrm{C} 1020$} & \multirow{3}{*}{$\begin{array}{l}\text { Expansion } \\
\text { Joint }\end{array}$} & C102010 Strip-Seal & & \\
\hline & & & & C102020 Modular & & \\
\hline & & & & C102030 Finger Plate & & \\
\hline & & \multirow[t]{2}{*}{ C1030 } & \multirow{2}{*}{$\begin{array}{l}\text { Protective } \\
\text { Coats }\end{array}$} & C103010 Preparation & & \\
\hline & & & & C103020 Application & & \\
\hline
\end{tabular}




\begin{tabular}{|c|c|c|c|c|c|c|}
\hline $\begin{array}{c}\text { Level } 1 \\
\text { Major Group } \\
\text { Elements }\end{array}$ & $\begin{array}{c}\text { Level } 2 \\
\text { Group Elements }\end{array}$ & \multicolumn{2}{|c|}{$\begin{array}{c}\text { Level } 3 \\
\text { Individual Elements }\end{array}$} & $\begin{array}{c}\text { Level } 4 \\
\text { Sub-Elements }\end{array}$ & \multirow[t]{2}{*}{$\begin{array}{c}\text { Level } 5 \\
\text { Sub-Elements }\end{array}$} & \multirow[t]{2}{*}{$\begin{array}{c}\text { Level } 5 \\
\text { Field Requirements }\end{array}$} \\
\hline & & \multirow[t]{2}{*}{$\mathrm{C} 1040$} & \multirow{2}{*}{$\begin{array}{l}\text { Sacrificial } \\
\text { Beams }\end{array}$} & C104010 Fabrication & & \\
\hline & & & & C104020 Erection & & \\
\hline & & \multirow{5}{*}{\multicolumn{2}{|c|}{$\begin{array}{ll}\text { C1050 } & \begin{array}{l}\text { Drainage } \\
\text { System }\end{array}\end{array}$}} & C105010 Scuppers & & \\
\hline & & & & C105020 Drain Pipes & & \\
\hline & & & & \multirow[t]{3}{*}{ C105030 Buried Drains } & C10503010 Pipe & \\
\hline & & & & & $\begin{array}{ll}\text { C10503020 } & \text { Head Wall }\end{array}$ & \\
\hline & & & & & $\begin{array}{ll}\text { C10503030 } & \text { End Walls }\end{array}$ & \\
\hline & & \multirow[t]{5}{*}{ C1060 } & \multirow{5}{*}{$\begin{array}{l}\text { Inspection and } \\
\text { Maintenance } \\
\text { Systems }\end{array}$} & C106010 Hangers & & \\
\hline & & & & C106020 Beams & & \\
\hline & & & & C106030 Platform & & \\
\hline & & & & C106040 Railing & & \\
\hline & & & & C106050 Connections & & \\
\hline & \multirow{14}{*}{$\begin{array}{ll}\text { C20 } & \text { Traffic } \\
& \text { Protection }\end{array}$} & \multirow{7}{*}{\multicolumn{2}{|c|}{ C2010 Barriers }} & C201010 Parapet & & \\
\hline & & & & C201020 Railing & & \\
\hline & & & & C201030 Glare Screen & & \\
\hline & & & & C201040 Median & & \\
\hline & & & & C201050 Curb & & \\
\hline & & & & C201060 Guardrail & & \\
\hline & & & & C201070 Screen & & \\
\hline & & \multirow[t]{2}{*}{$\mathrm{C} 2020$} & \multirow{2}{*}{$\begin{array}{l}\text { Protective } \\
\text { Shields }\end{array}$} & C202010 Fabrication & & \\
\hline & & & & C202020 Erection & & \\
\hline & & \multirow{5}{*}{\multicolumn{2}{|c|}{$\begin{array}{ll}\text { C2030 } & \text { Traffic } \\
& \text { Controls }\end{array}$}} & C203010 Signals & & \\
\hline & & & & C203020 Arms & & \\
\hline & & & & C203030 Mast & & \\
\hline & & & & C203040 Base Plate & & \\
\hline & & & & C203050 Conduits & & \\
\hline
\end{tabular}




\begin{tabular}{|c|c|c|c|c|c|c|c|}
\hline $\begin{array}{c}\text { Level } 1 \\
\text { Major Group } \\
\text { Elements } \\
\end{array}$ & \multicolumn{2}{|c|}{$\begin{array}{c}\text { Level } 2 \\
\text { Group Elements }\end{array}$} & \multicolumn{2}{|c|}{$\begin{array}{c}\text { Level } 3 \\
\text { Individual Elements }\end{array}$} & $\begin{array}{c}\text { Level } 4 \\
\text { Sub-Elements }\end{array}$ & \multirow[t]{2}{*}{$\begin{array}{c}\text { Level } 5 \\
\text { Sub-Elements }\end{array}$} & \multirow[t]{2}{*}{$\begin{array}{c}\text { Level } 5 \\
\text { Field Requirements }\end{array}$} \\
\hline & & \multirow{17}{*}{$\begin{array}{l}\text { Other } \\
\text { Protection }\end{array}$} & \multirow{5}{*}{\multicolumn{2}{|c|}{ C3010 Lighting }} & C301010 Lights & & \\
\hline & & & & & C301020 Arms & & \\
\hline & & & & & C301030 Mast & & \\
\hline & & & & & C301040 Base Plate & & \\
\hline & & & & & C301050 Conduits & & \\
\hline & & & \multirow{4}{*}{\multicolumn{2}{|c|}{ C3020 Signage }} & C302010 Sign Board & & \\
\hline & & & & & C302020 Support & & \\
\hline & & & & & C302030 Lights & & \\
\hline & & & & & C302040 Conduits & & \\
\hline & & & \multirow{3}{*}{\multicolumn{2}{|c|}{$\begin{array}{ll}\text { C3030 } & \text { Sound Barrier } \\
& \text { Walls }\end{array}$}} & C303010 Panels & & \\
\hline & & & & & C303020 Support & & \\
\hline & & & & & C303030 Connections & & \\
\hline & & & \multirow{3}{*}{\multicolumn{2}{|c|}{$\begin{array}{ll}\text { C3040 } & \text { Air Pressure } \\
& \text { Barriers }\end{array}$}} & C304010 Panels & & \\
\hline & & & & & $\begin{array}{ll}\text { C304020 Support } \\
\text { S3 }\end{array}$ & & \\
\hline & & & & & C304030 Connections & & \\
\hline & & & \multirow{2}{*}{\multicolumn{2}{|c|}{ C3050 Enclosure }} & C305010 Vertical Envelope & & \\
\hline & & & & & C305020 Roof & & \\
\hline \multirow[t]{9}{*}{ D Sitework } & \multirow[t]{9}{*}{ D10 } & \multirow{9}{*}{$\begin{array}{l}\text { Site } \\
\text { Preparation }\end{array}$} & \multirow[t]{2}{*}{ D1010 } & \multirow{2}{*}{$\begin{array}{l}\text { Clearing and } \\
\text { Grubbing }\end{array}$} & D101010 Clearing & & \\
\hline & & & & & D101020 Grubbing & & \\
\hline & & & \multirow{3}{*}{\multicolumn{2}{|c|}{$\begin{array}{ll}\text { D1020 } & \begin{array}{l}\text { Demolition and } \\
\text { Relocation }\end{array}\end{array}$}} & D102010 Structures & & \\
\hline & & & & & D102020 Utilities & & \\
\hline & & & & & D102030 Trees & & \\
\hline & & & \multirow{2}{*}{\multicolumn{2}{|c|}{ D1030 $\quad$ Earthwork }} & D103010 Cut & & \\
\hline & & & & & $\begin{array}{ll}\text { D103020 Fill } \\
\end{array}$ & & \\
\hline & & & \multirow[t]{2}{*}{ D1040 } & \multirow{2}{*}{$\begin{array}{l}\text { Hazardous } \\
\text { Material } \\
\text { Handling } \\
\end{array}$} & D104010 Excavation & & \\
\hline & & & & & D104020 Disposal & & \\
\hline
\end{tabular}




\begin{tabular}{|c|c|c|c|c|c|c|}
\hline $\begin{array}{c}\text { Level } 1 \\
\text { Major Group } \\
\text { Elements } \\
\end{array}$ & $\begin{array}{c}\text { Level } 2 \\
\text { Group Elements }\end{array}$ & \multicolumn{2}{|c|}{$\begin{array}{c}\text { Level 3 } \\
\text { Individual Elements }\end{array}$} & $\begin{array}{c}\text { Level } 4 \\
\text { Sub-Elements }\end{array}$ & \multirow[t]{2}{*}{$\begin{array}{c}\text { Level } 5 \\
\text { Sub-Elements }\end{array}$} & \multirow[t]{2}{*}{$\begin{array}{c}\text { Level } 5 \\
\text { Field Requirements }\end{array}$} \\
\hline & & \multirow[t]{2}{*}{ D1050 } & \multirow{2}{*}{$\begin{array}{l}\text { Environmental } \\
\text { Restoration/ } \\
\text { Replacement }\end{array}$} & $\begin{array}{ll}\text { D105010 } & \begin{array}{l}\text { Environmental } \\
\text { Restoration }\end{array} \\
\end{array}$ & & \\
\hline & & & & $\begin{array}{ll}\text { D105020 } & \begin{array}{l}\text { Environmental } \\
\text { Replacement }\end{array} \\
\end{array}$ & & \\
\hline & \multirow{10}{*}{$\begin{array}{ll}\text { D20 } & \text { Approach } \\
& \text { Construction }\end{array}$} & \multirow[t]{3}{*}{ D2010 } & \multirow[t]{3}{*}{ Approach Slab } & D201010 Reinforcement & & \\
\hline & & & & D201020 $\quad$ Placement & & \\
\hline & & & & D201030 Finishing & & \\
\hline & & \multirow[t]{4}{*}{ D2020 } & \multirow[t]{4}{*}{ Sleeper Slab } & D202010 Excavation & & \\
\hline & & & & D202020 Reinforcement & & \\
\hline & & & & D202030 Placement & & \\
\hline & & & & D202040 Backfilling & & \\
\hline & & \multirow[t]{3}{*}{ D2030 } & \multirow{3}{*}{$\begin{array}{l}\text { Earth } \\
\text { Retention } \\
\text { System }\end{array}$} & D203010 Foundation & & \\
\hline & & & & D203020 Wall & & \\
\hline & & & & D203030 Cap & & \\
\hline
\end{tabular}




\section{Appendix B An Illustrated Guide to the Proposed UNIFORMAT II Classification of Bridge Elements}

This appendix is designed as an illustrated guide to the proposed UNIFORMAT II classification of bridge elements. The appendix includes diagrams, engineering drawings, and, where appropriate, photographs to identify the appearance of each element and how it fits into the overall framework.

The figures presented in this appendix are organized around the proposed UNIFORMAT II hierarchy. Figures are arranged by Major Group Element and Group Element, with Individual Elements clearly marked in the diagram, engineering drawing, or photograph. For each Major Group Element, the Group Elements are presented in the sequence they are listed in Table 2.2. For each Group Element, the Individual Elements are labeled in one of more figures associated with that Group element. In some case, Sub-Elements are also listed.

Figure B.1 Major Group Elements: A Substructure, B Superstructure

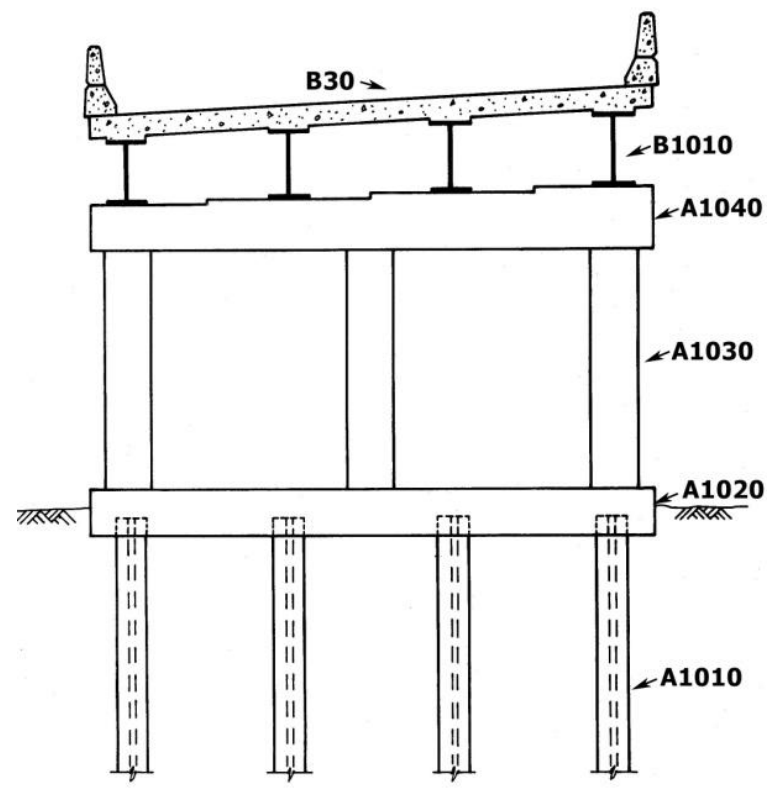

Source: Illinois Department of Transportation 
Figure B.2 Group Elements: A10 Piers

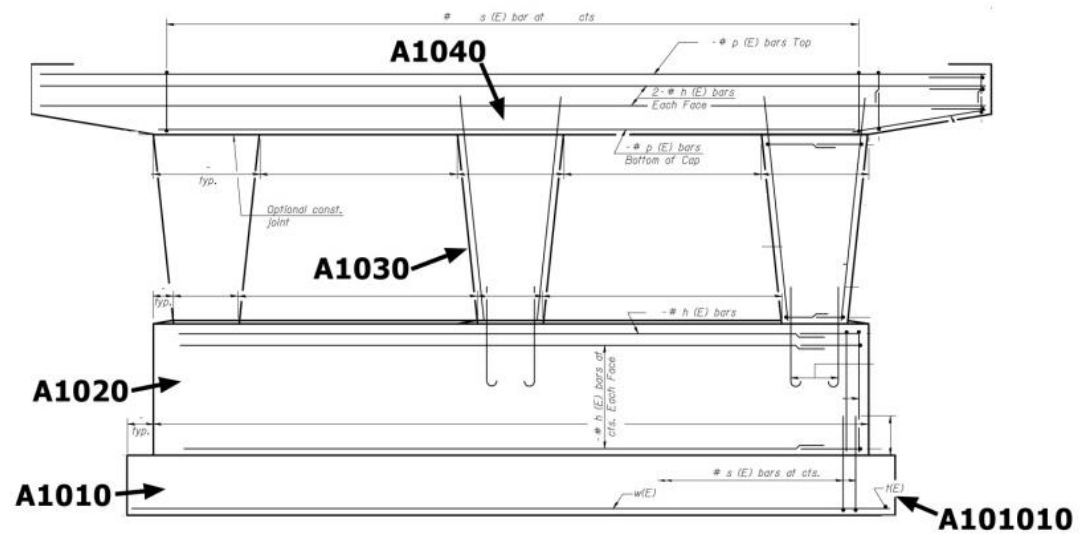

Source: Illinois Department of Transportation

Figure B.3 Group Elements: A10 Piers

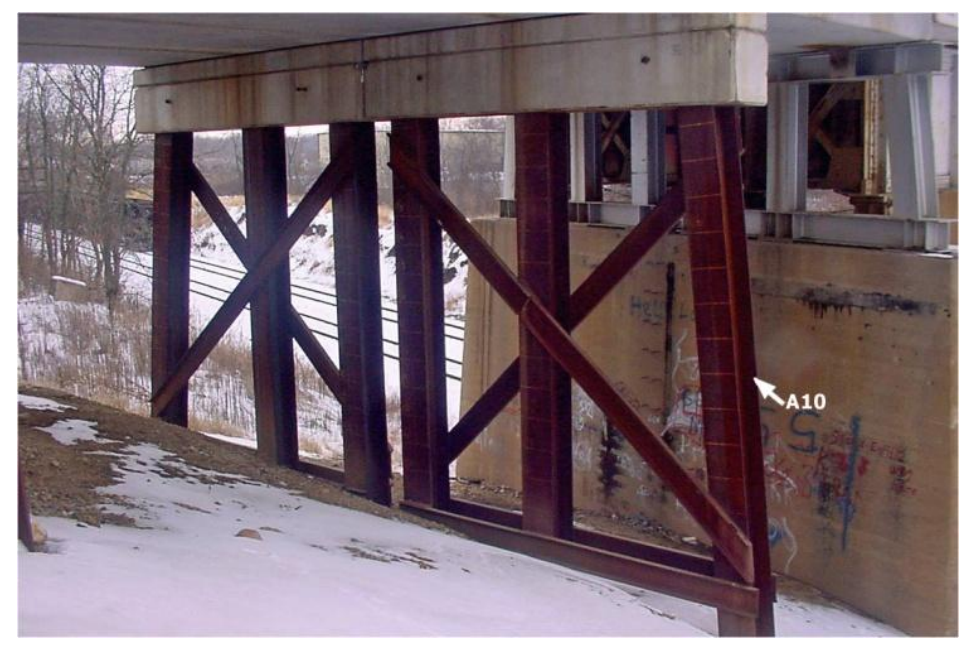

Source: Alfred Benesch \& Company 
Figure B.4 Individual Elements: A1010 Foundations (Field Requirements: A101010X1 (Cofferdam))

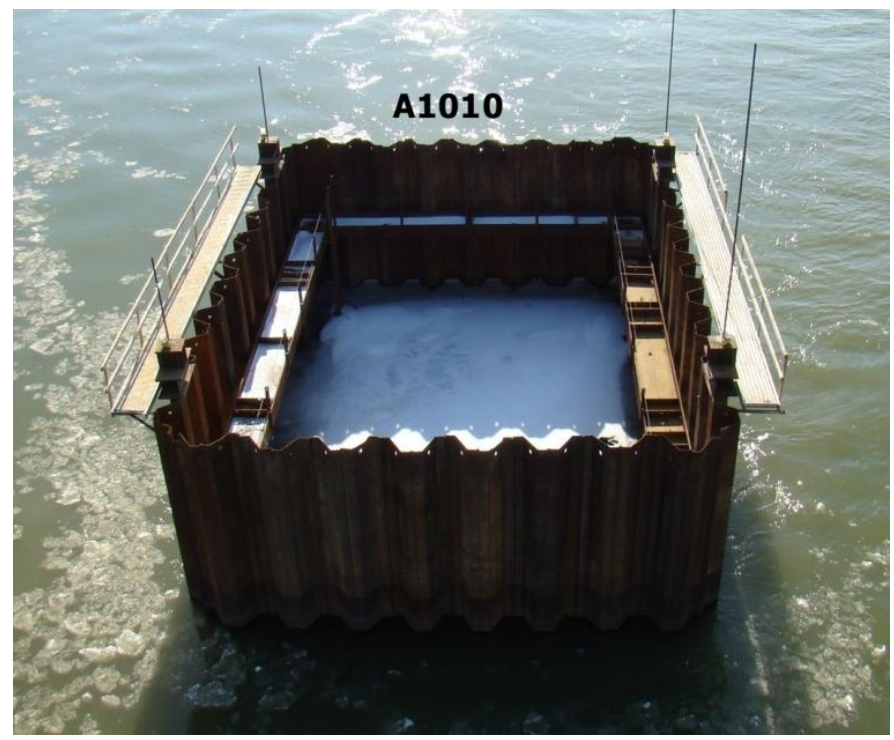

Source: Alfred Benesch \& Company

Figure B.5 Individual Elements: A1010 Foundations (Sub-Elements: A101010 Spread Footings (Excavation))

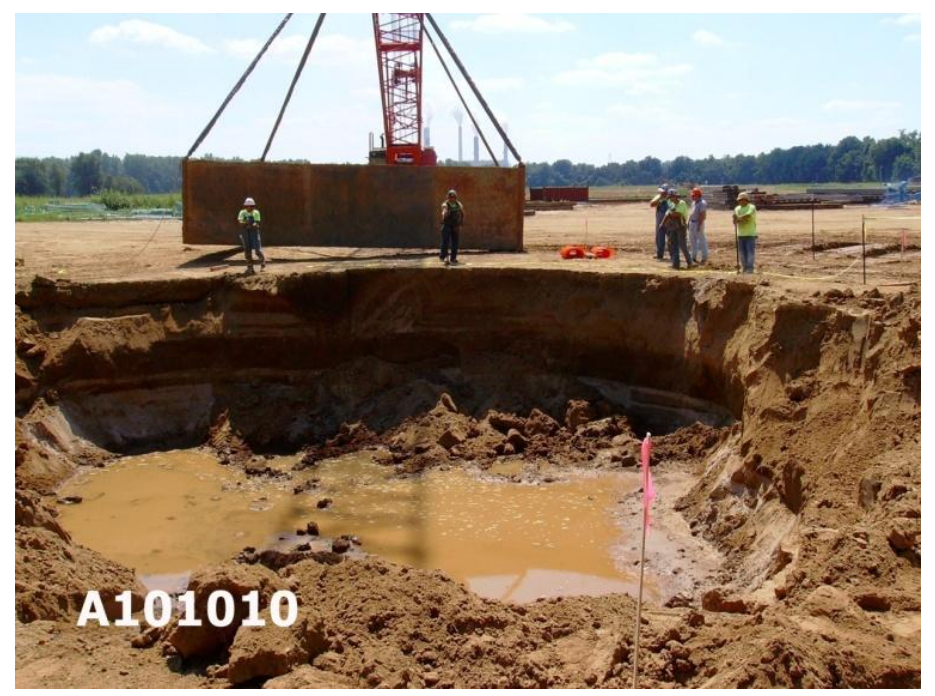

Source: Alfred Benesch \& Company 
Figure B.6 Individual Elements: A1010 Foundations (Sub-Elements: A101020 Piles)

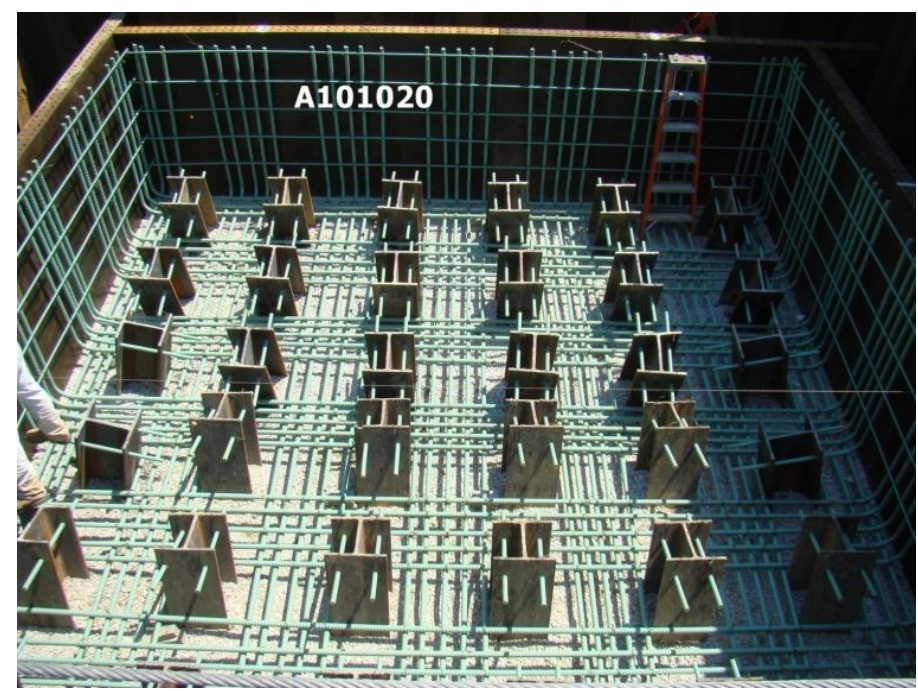

Source: Alfred Benesch \& Company

Figure B.7 Individual Elements: A1010 Foundations (Sub-Elements: A101030 Drilled Shafts)

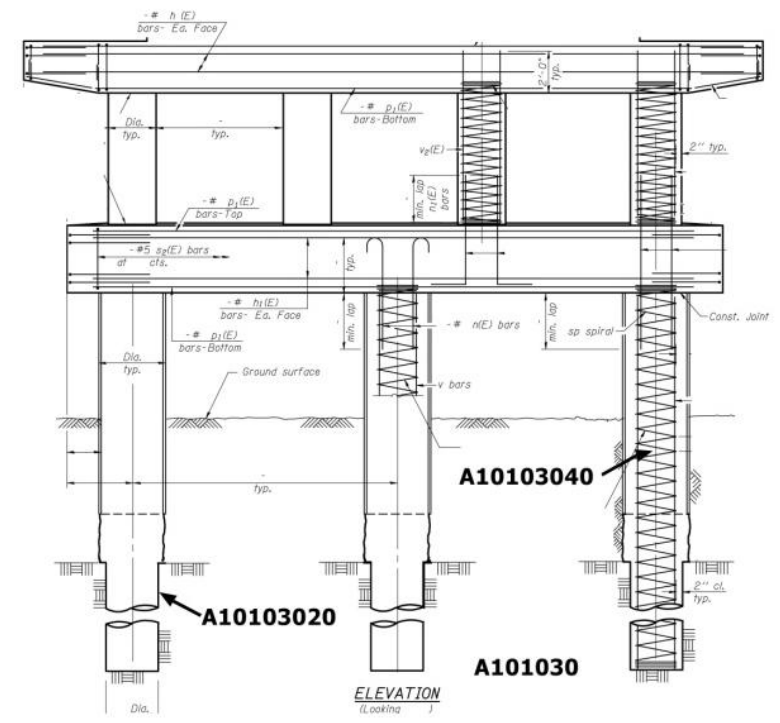

Source: Illinois Department of Transportation 
Figure B.8 Individual Elements: A1020 Walls, A1030 Columns, A1040 Cap Beams

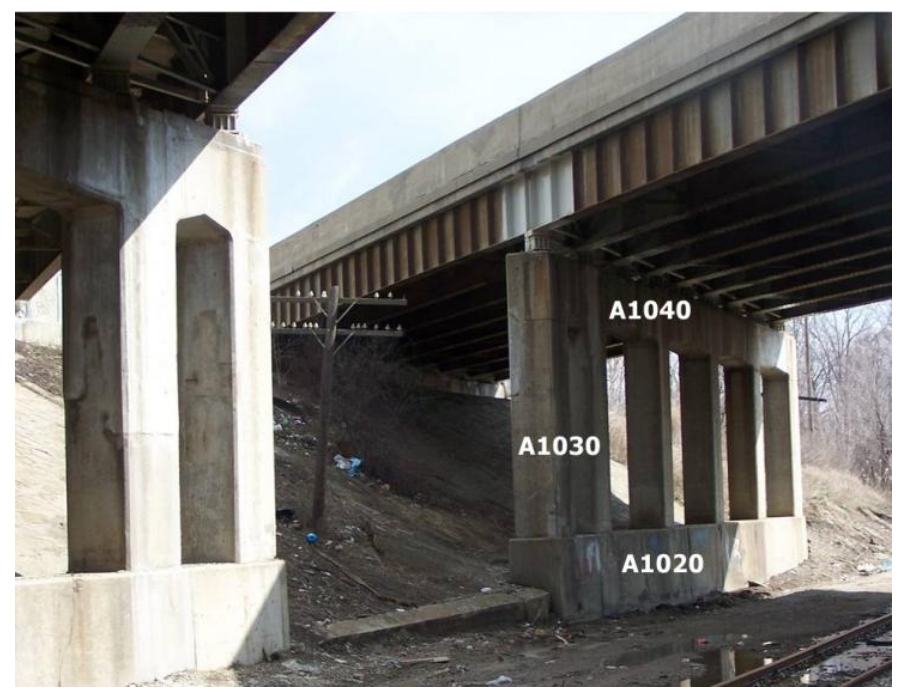

Source: Alfred Benesch \& Company

Figure B.9 Individual Elements: A1040 Cap Beams (Sub-Elements: A10401020 Reinforcement)

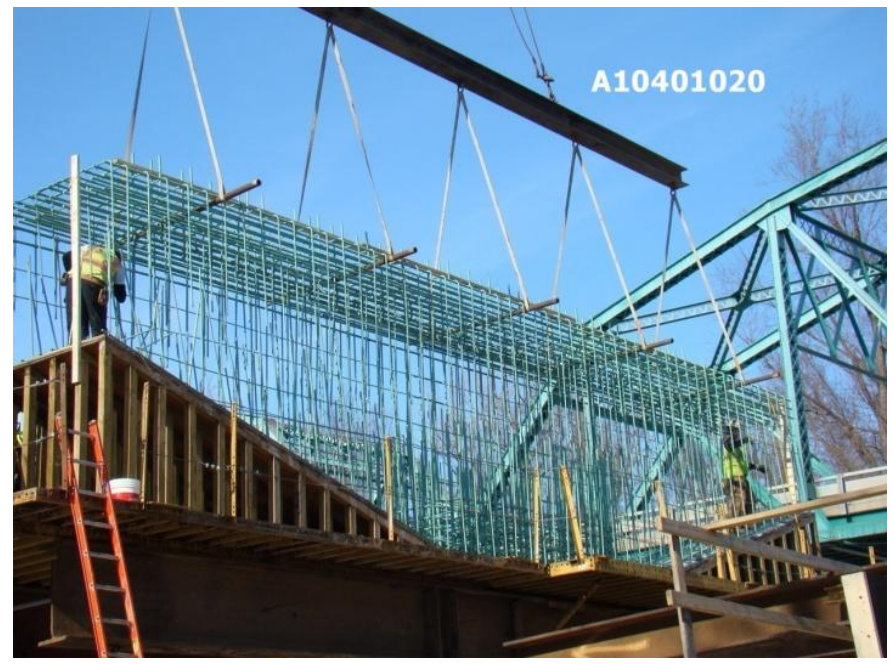

Source: Alfred Benesch \& Company 
Figure B.10 Individual Elements: A1040 Cap Beams

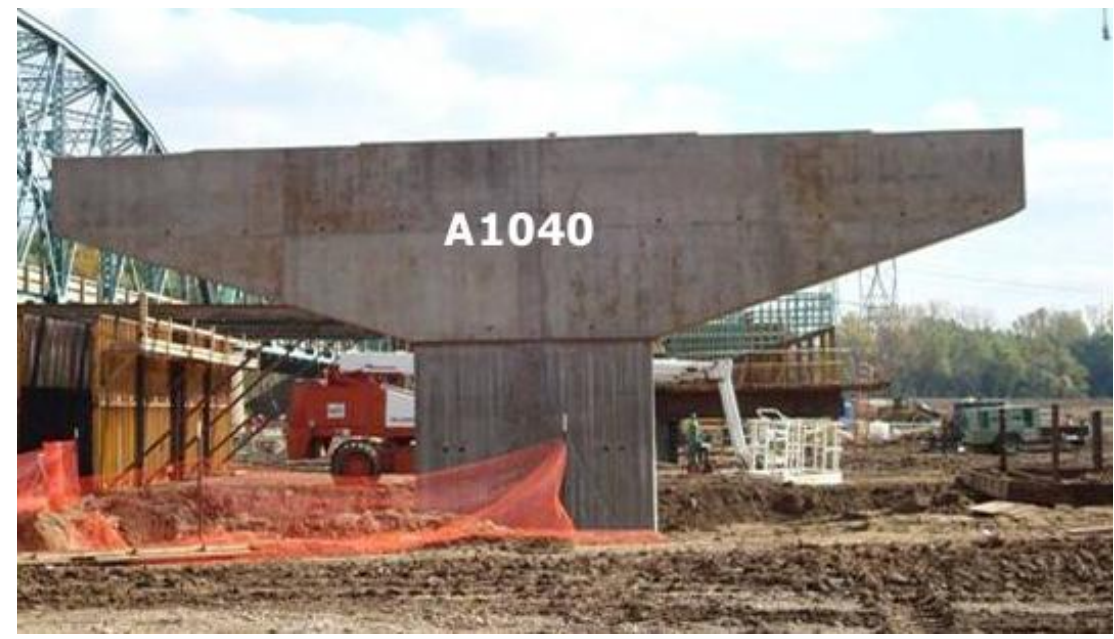

Source: Alfred Benesch \& Company

\section{Figure B.11 Group Elements: A20 Towers}

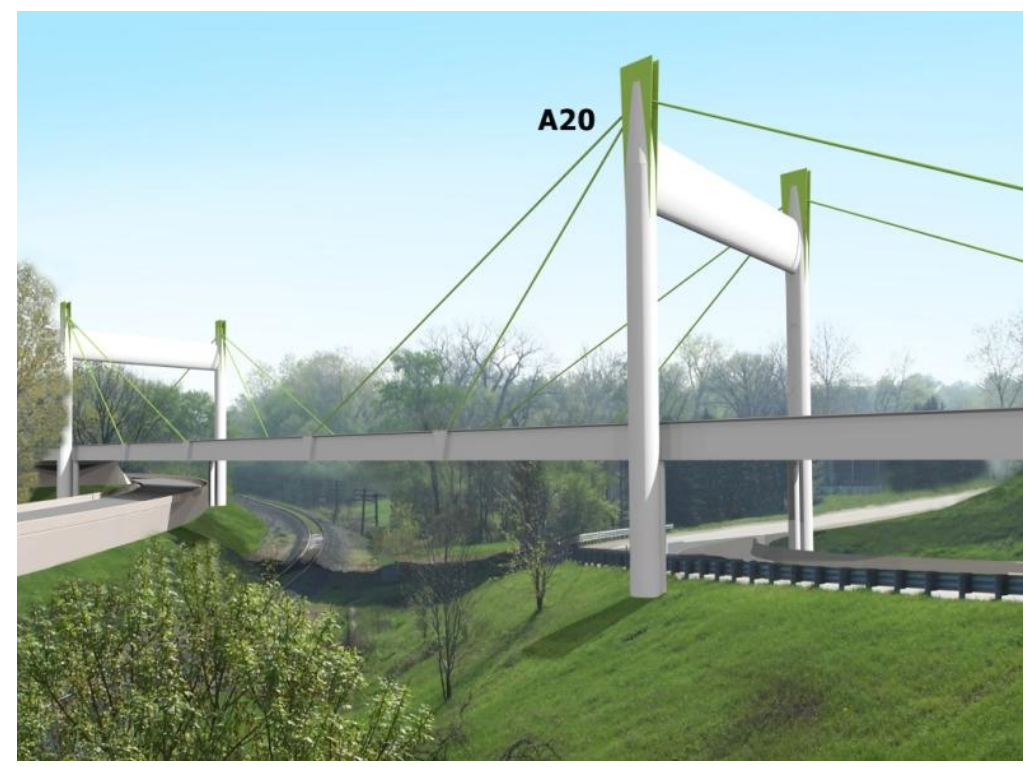

Source: Alfred Benesch \& Company 
Figure B.12 Group Elements: A30 Abutments

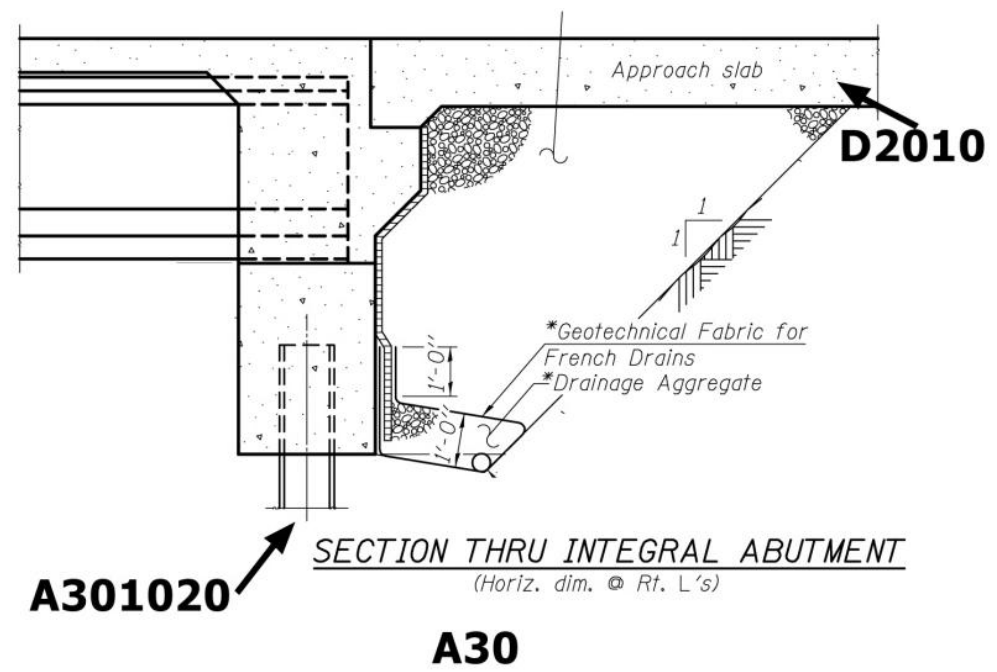

Source: Illinois Department of Transportation

Figure B.13 Individual Elements: A3010 Foundations, A3020 Stems, A3030 Wing Walls
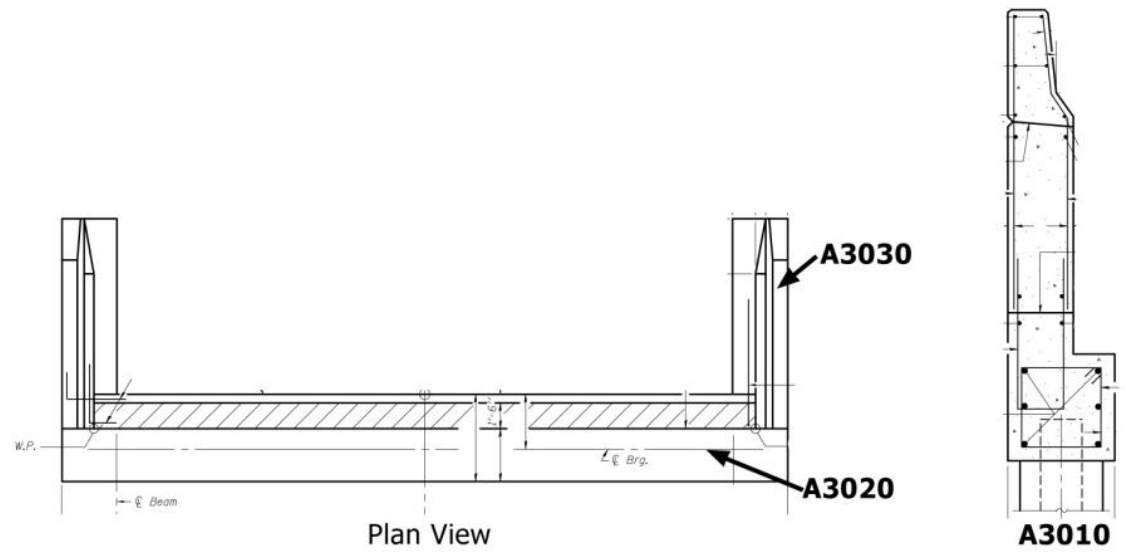

Section View

Source: Illinois Department of Transportation 
Figure B.14 Individual Elements: A3010 Foundations (Sub-Elements: A301020 Piles, A30102030 Pile Cap)

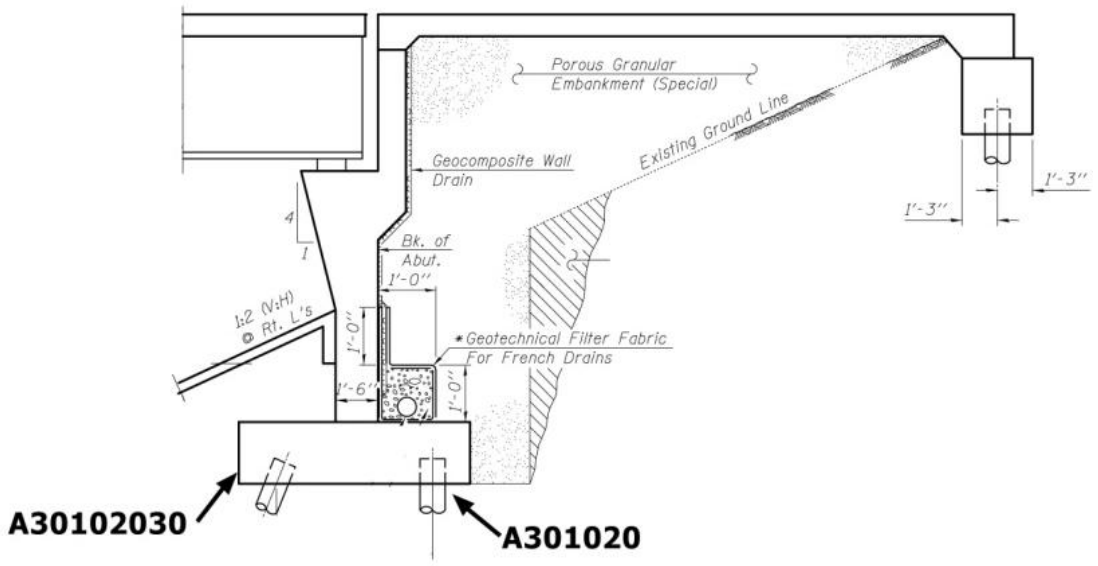

Source: Illinois Department of Transportation

Figure B.15 Individual Elements: A3020 Stems

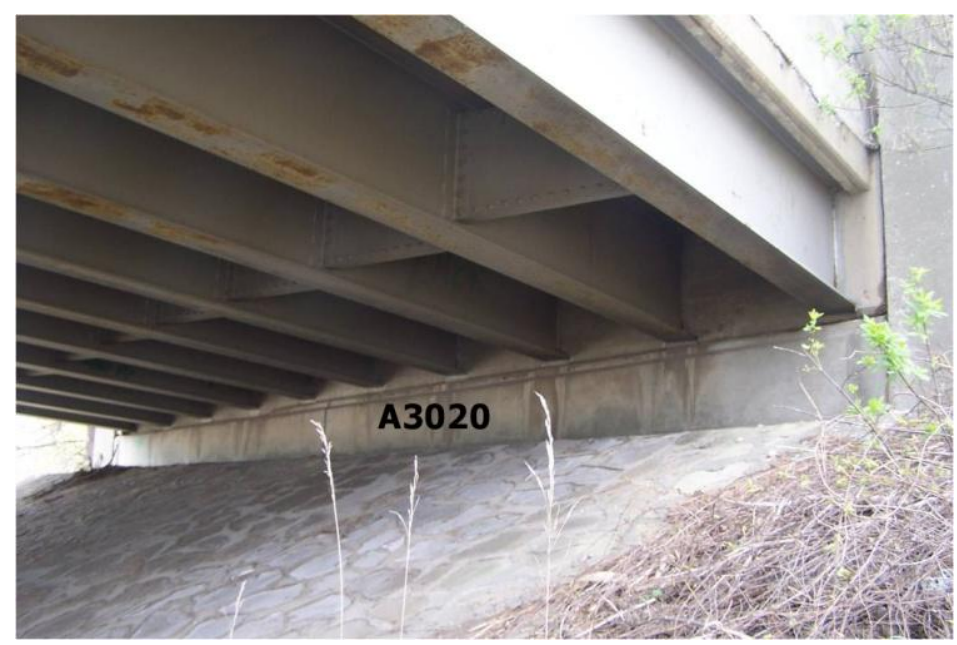

Source: Alfred Benesch \& Company 
Figure B.16 Individual Elements: A3030 Wing Walls

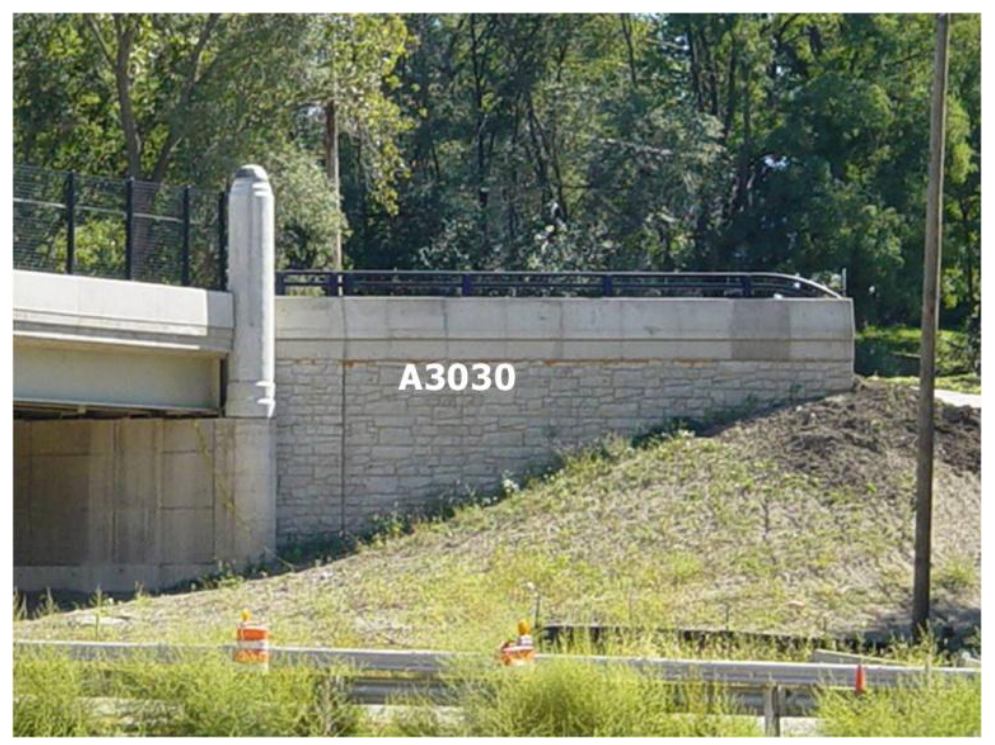

Source: Alfred Benesch \& Company

Figure B.17 Group Elements: A40 Other Supports (Individual Elements: A4010 Thrust Blocks)

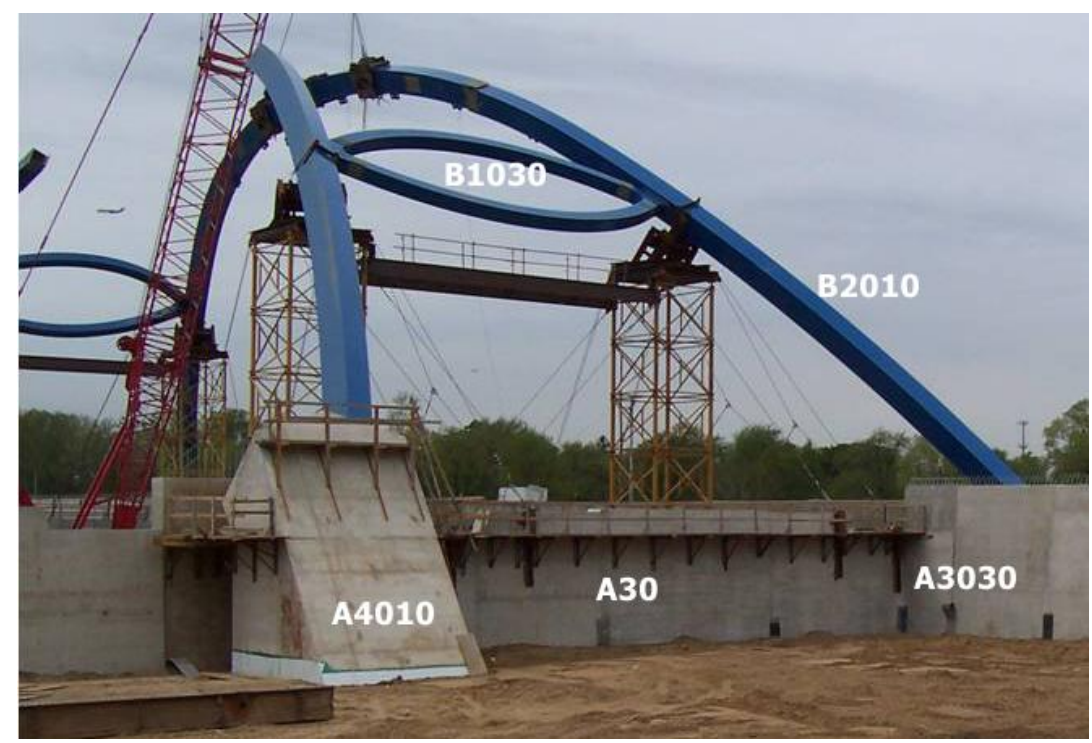

Source: Alfred Benesch \& Company 
Figure B.18 Individual Elements: A4010 Thrust Blocks (Sub-Elements: A401020 Foundations (A40102020 Piles))

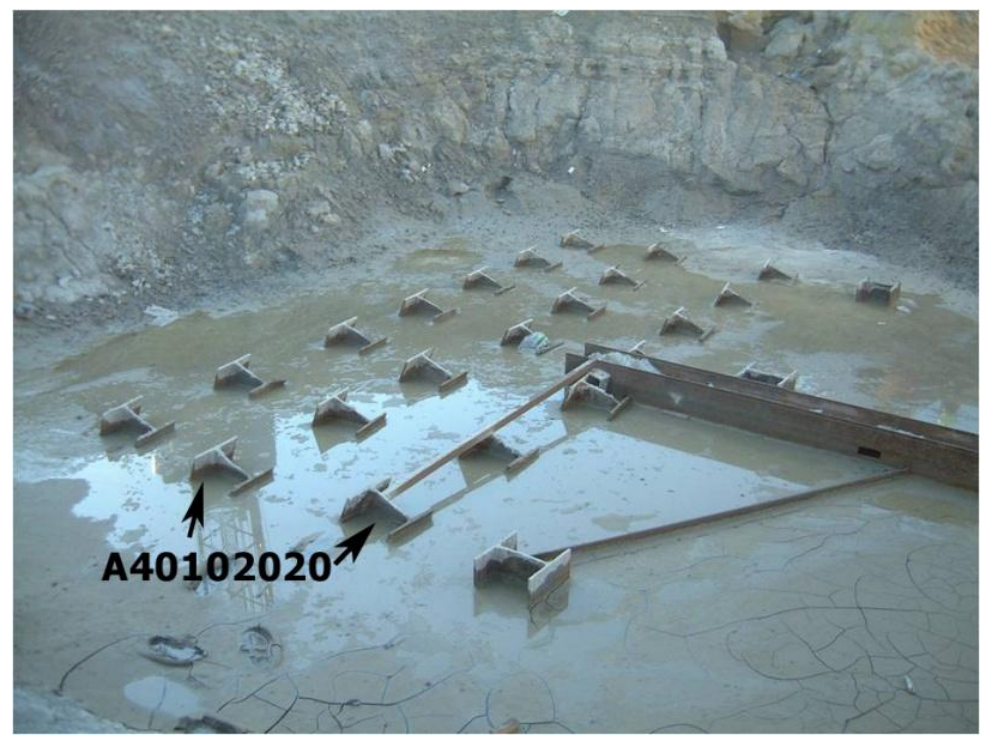

Source: Alfred Benesch \& Company

Figure B.19 Group Elements: B10 Short Span Assemblies (Individual Elements: B1010 Flexural Member, B1020 Diaphragms), B30 Deck

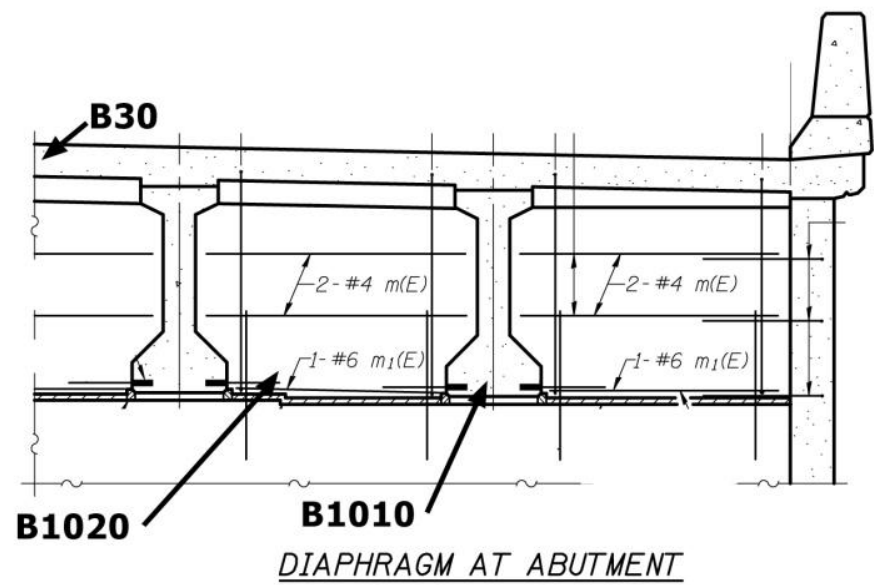

Source: Illinois Department of Transportation 
Figure B.20 Individual Elements: B1010 Flexural Members, B1020 Diaphragms

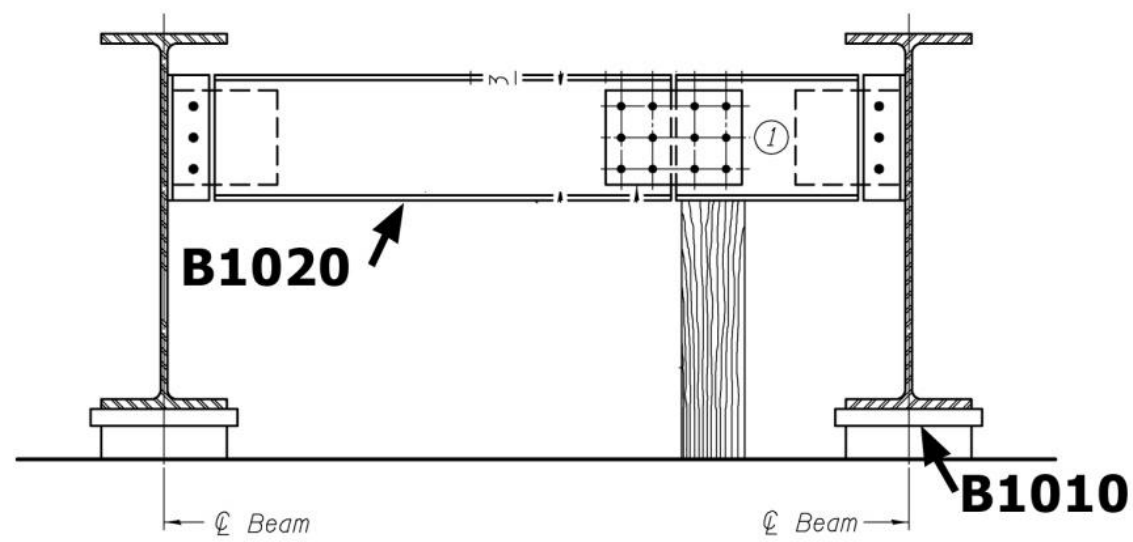

Source: Illinois Department of Transportation

Figure B.21 Individual Elements: B1020 Diaphragms

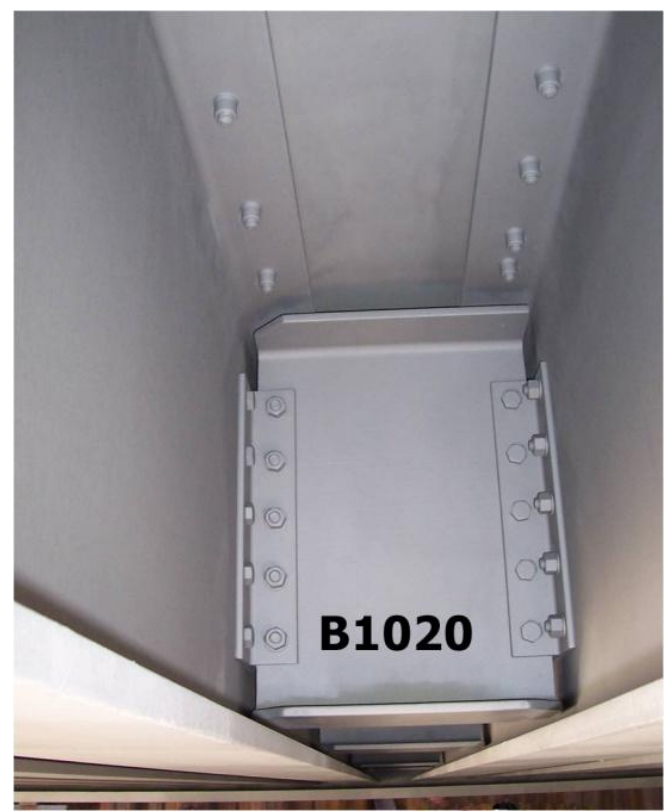

Source: Alfred Benesch \& Company 
Figure B.22 Individual Elements: B1030 Bracings
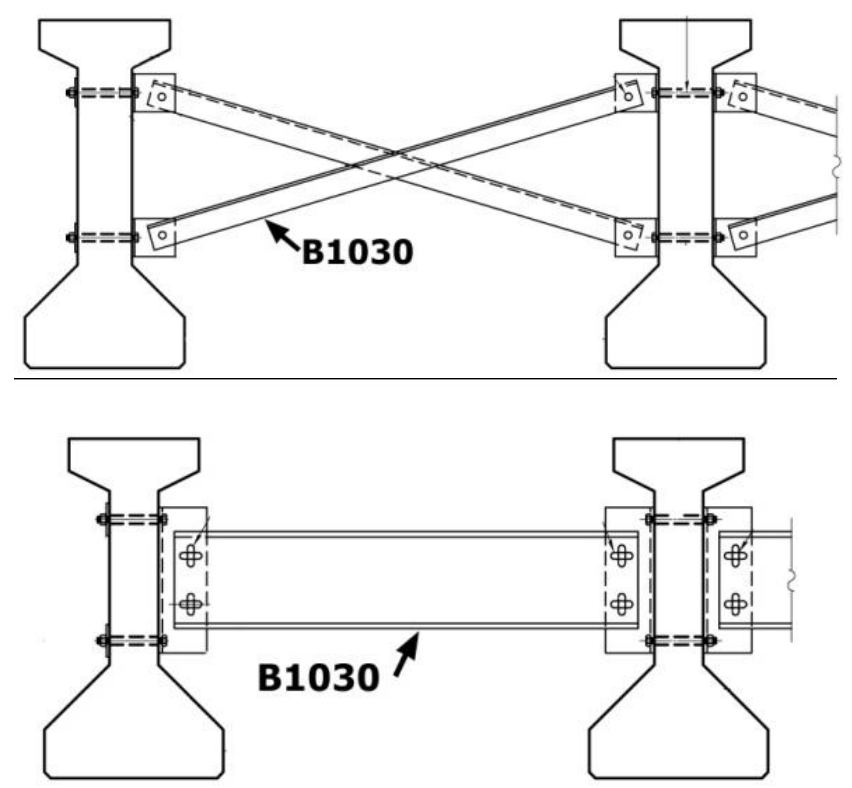

Source: Illinois Department of Transportation

Figure B.23 Individual Elements: B1030 Bracings

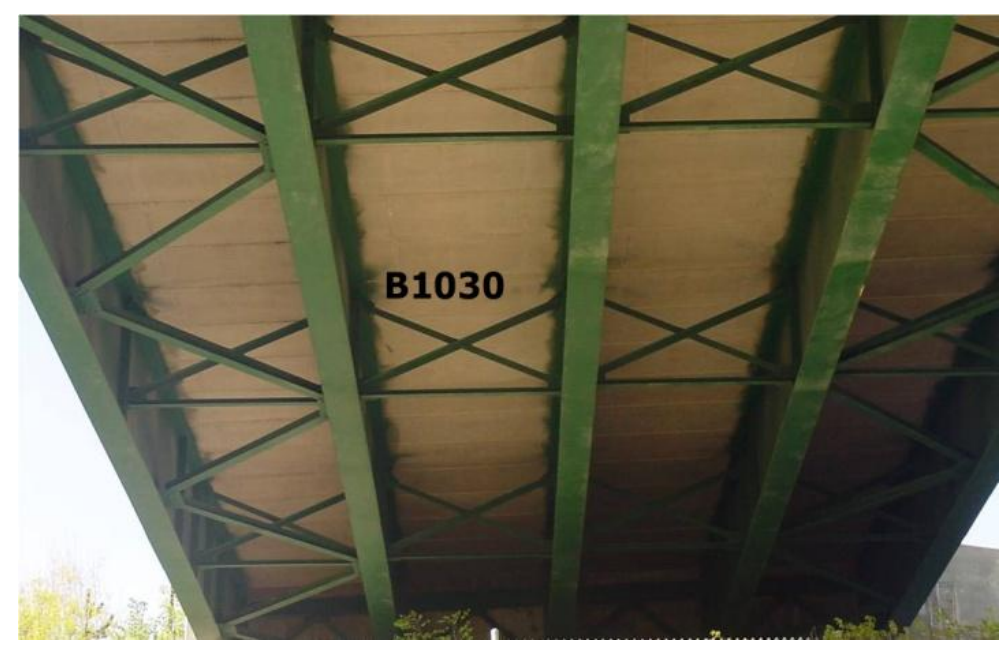

Source: Alfred Benesch \& Company 
Figure B.24 Individual Elements: B1040 Bearings

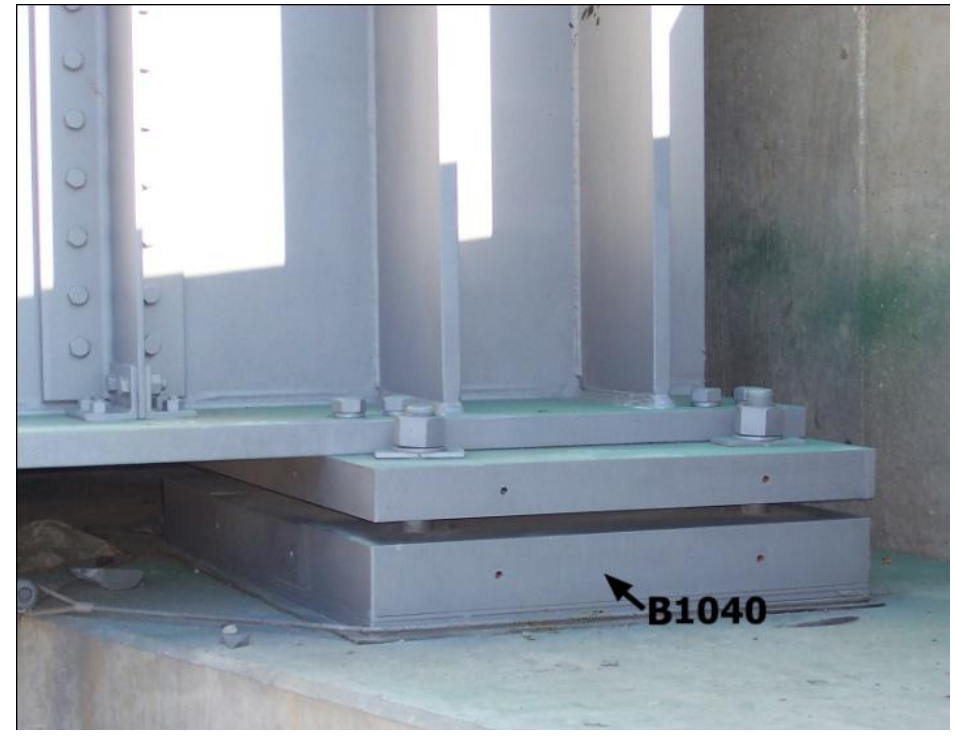

Source: Alfred Benesch \& Company

Figure B.25 Individual Elements: B1010 Flexural Members, B1030 Bracings, B1040 Bearings

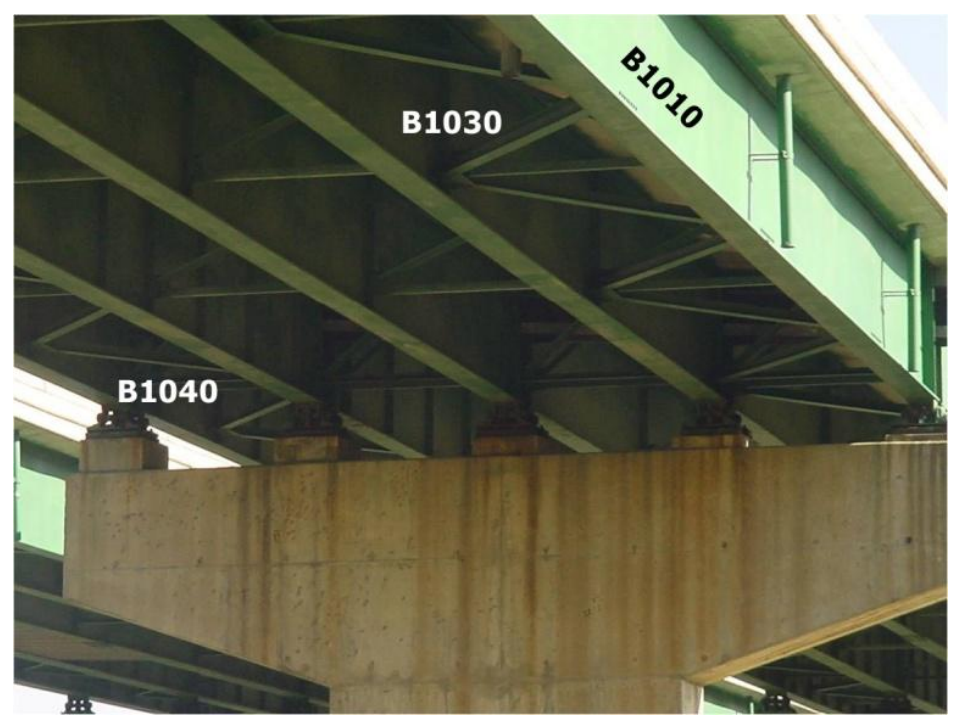

Source: Alfred Benesch \& Company 
Figure B.26 Group Elements: B20 Long Span Assemblies (Individual Elements: B2010 Ribs, B2030 Hangers)

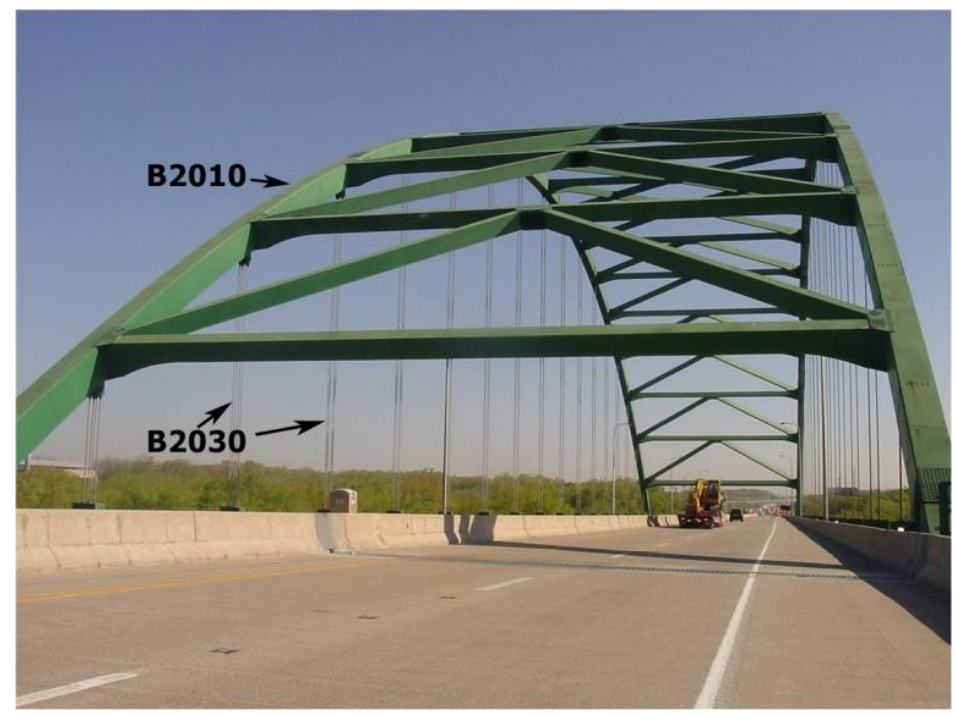

Source: Alfred Benesch \& Company

Figure B.27 Individual Elements: B2030 Hangers

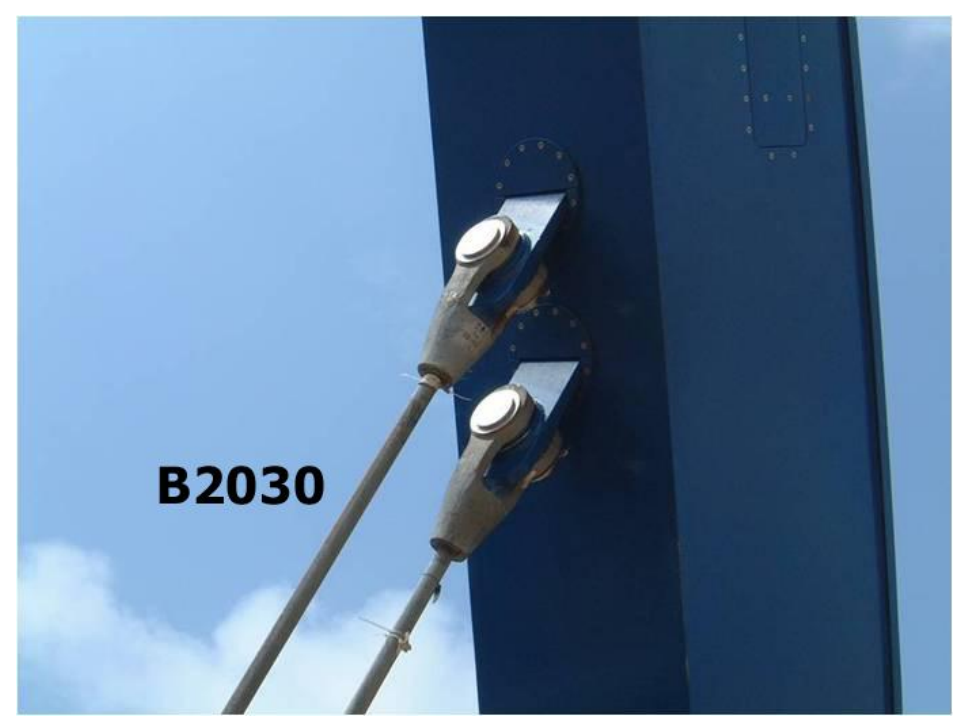

Source: Alfred Benesch \& Company 
Figure B.28 Individual Elements: B2010 Ribs, B2050 Ties

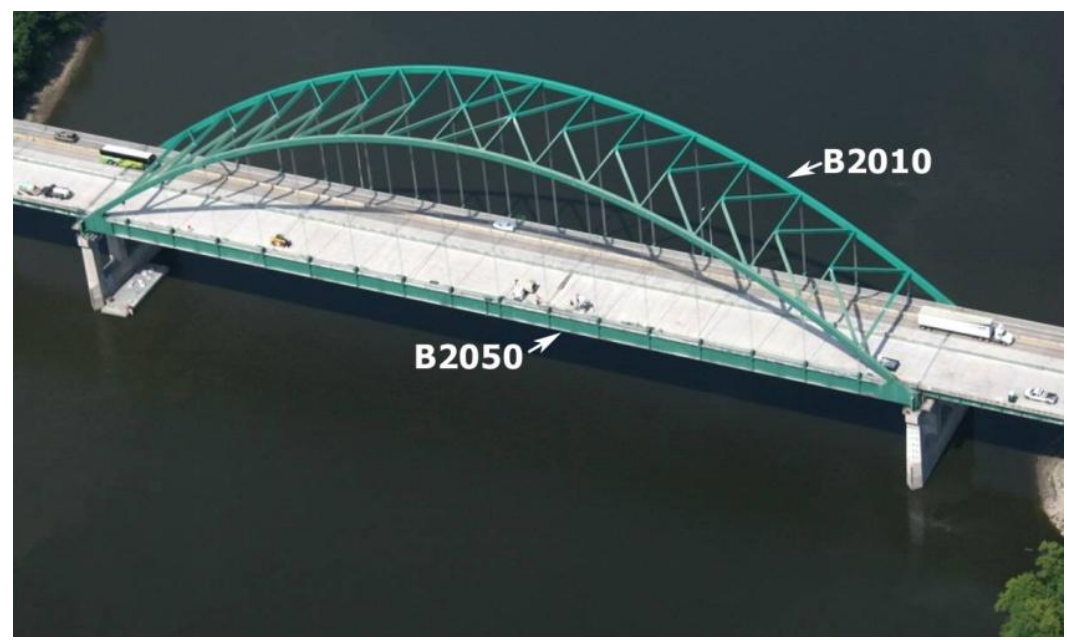

Source: Alfred Benesch \& Company

Figure B.29 Individual Elements: B2040 Spandrels

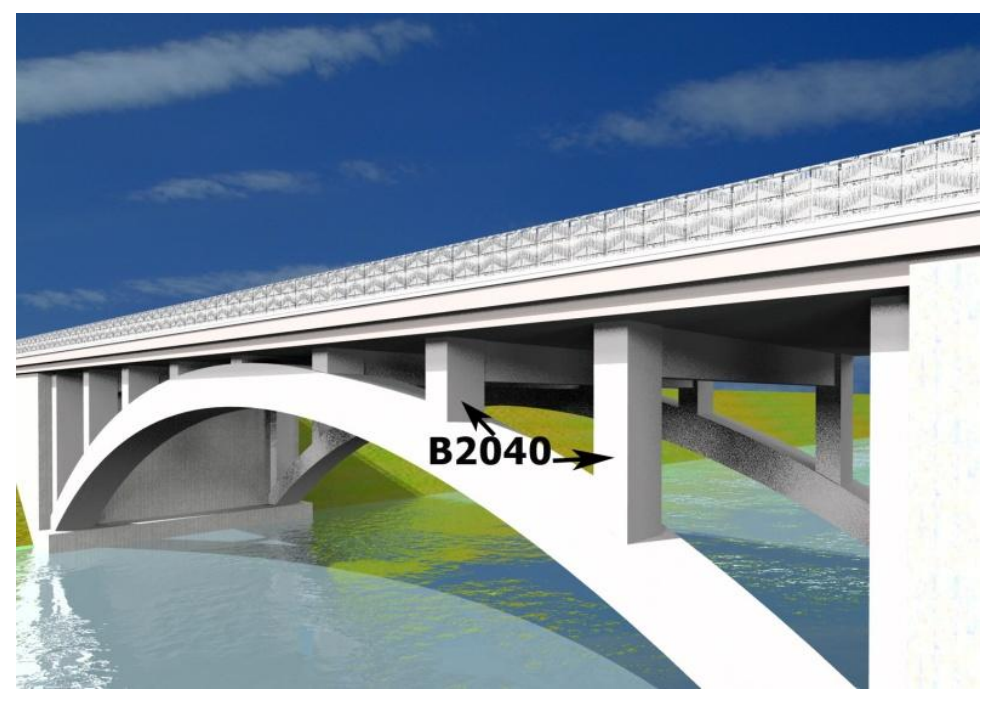

Source: Alfred Benesch \& Company 
Figure B.30 Individual Elements: B2060 Truss Members

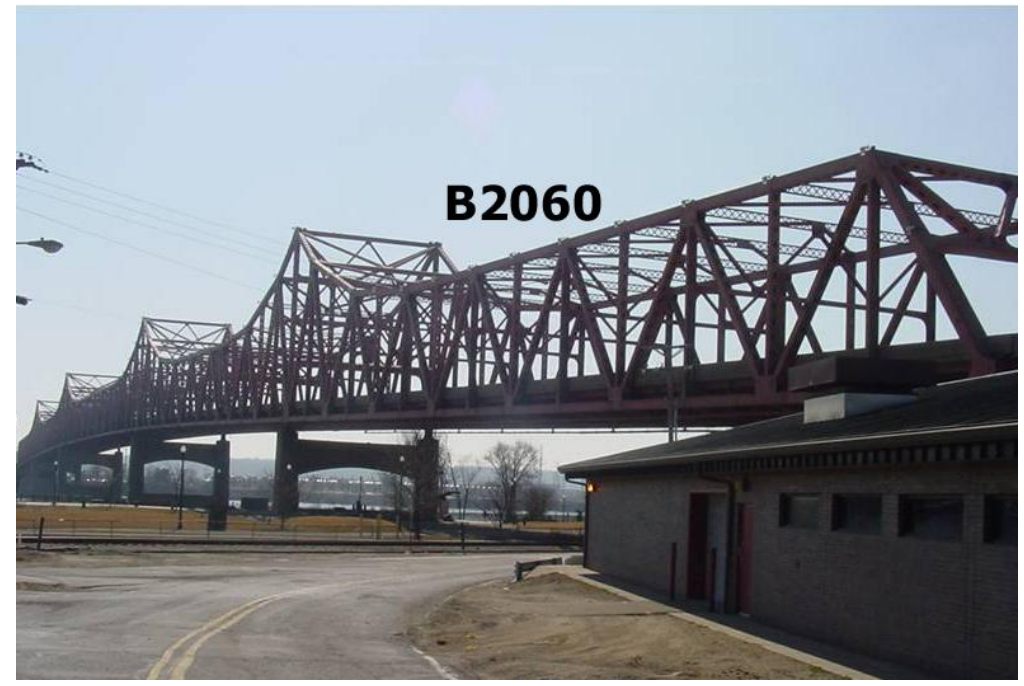

Source: Alfred Benesch \& Company

Figure B.31 Individual Elements: B2070 Segmental Box Girders

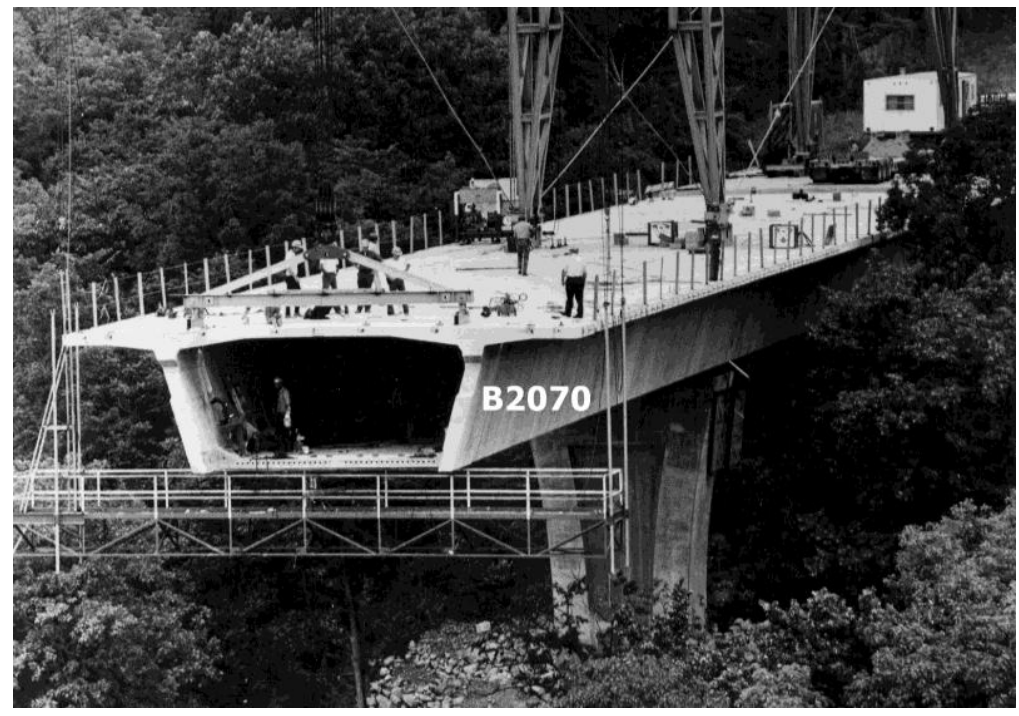

Source: Alfred Benesch \& Company 
Figure B.32 Group Elements: B30 Deck (Individual Elements: B3010 Structural Surface)

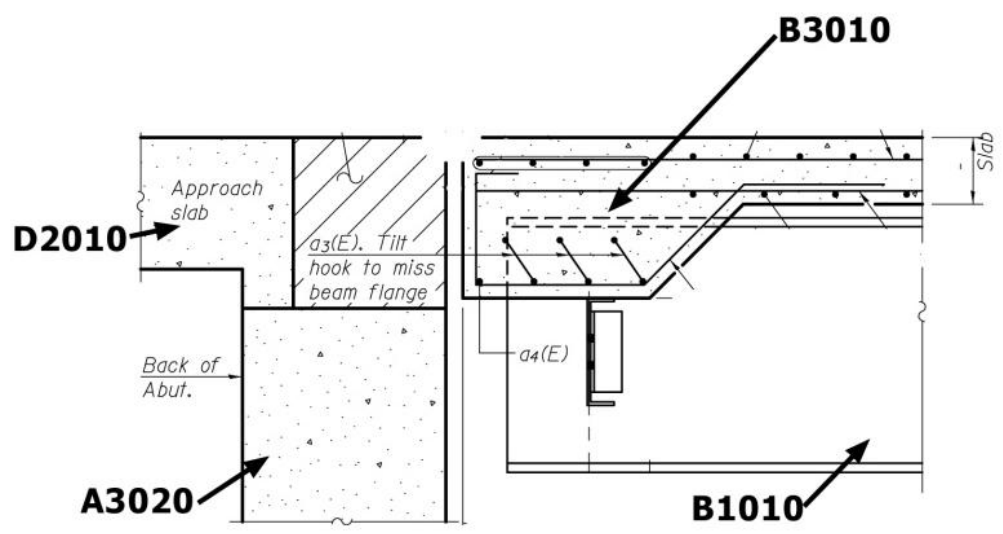

Source: Illinois Department of Transportation

Figure B.33 Individual Elements: B3020 Wearing Surface

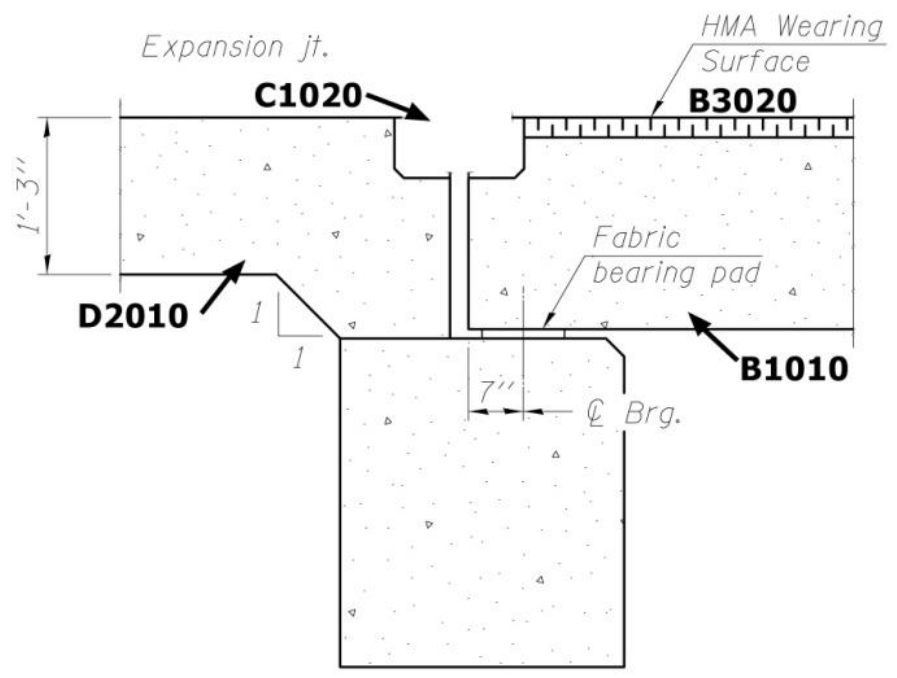

Source: Illinois Department of Transportation 
Figure B.34 Group Elements: C10 Structure Protection (Individual Elements:C1010 Slope Walls)

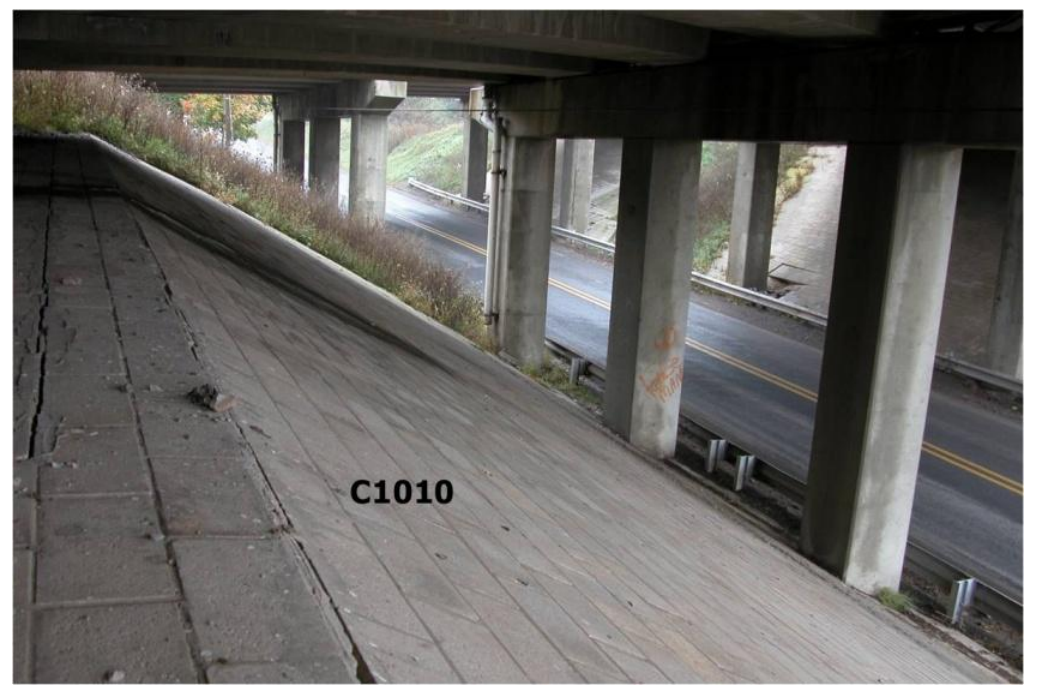

Source: Alfred Benesch \& Company

Figure B.35 Individual Elements: C1020 Expansion Joints

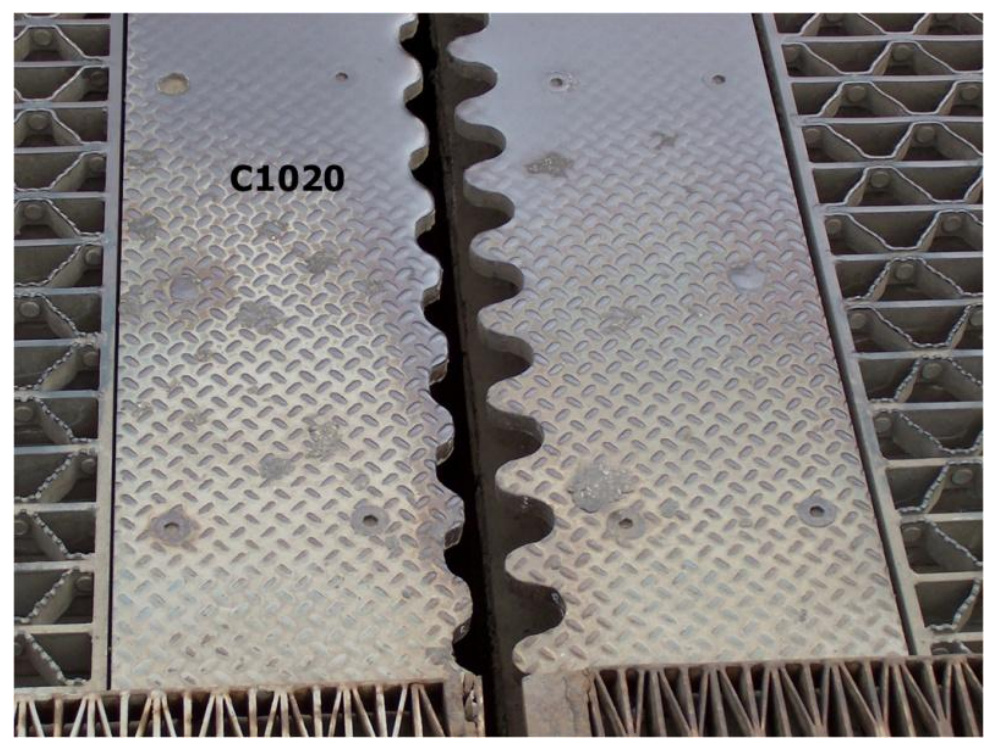

Source: Alfred Benesch \& Company 
Figure B.36 Individual Elements: C1030 Protection Coats

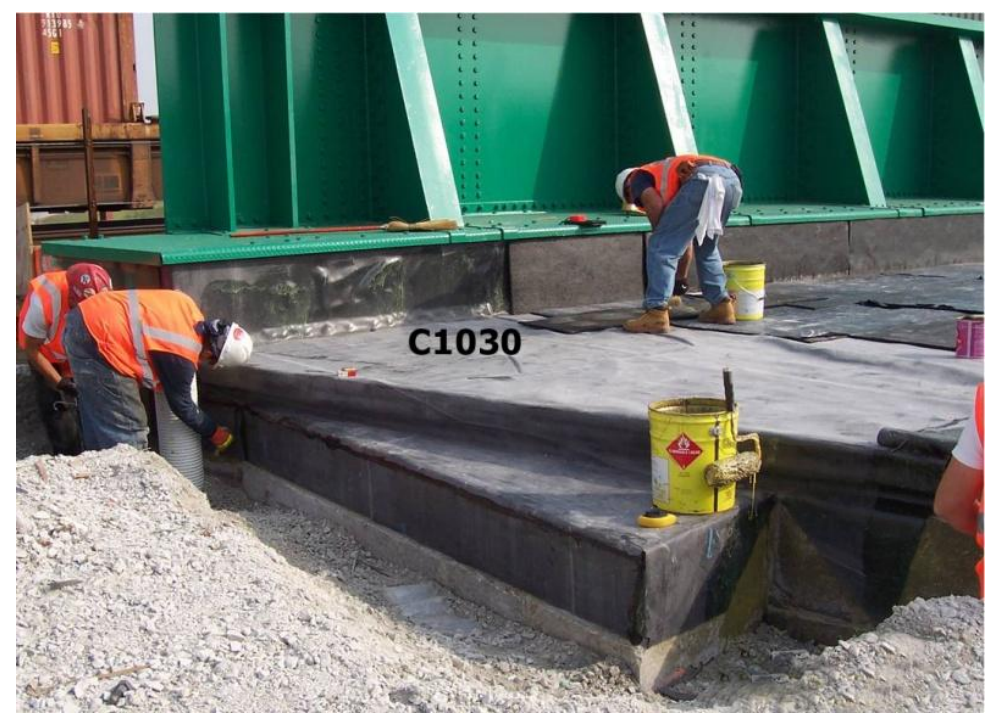

Source: Alfred Benesch \& Company

Figure B.37 Individual Elements: C1040 Sacrificial Beams

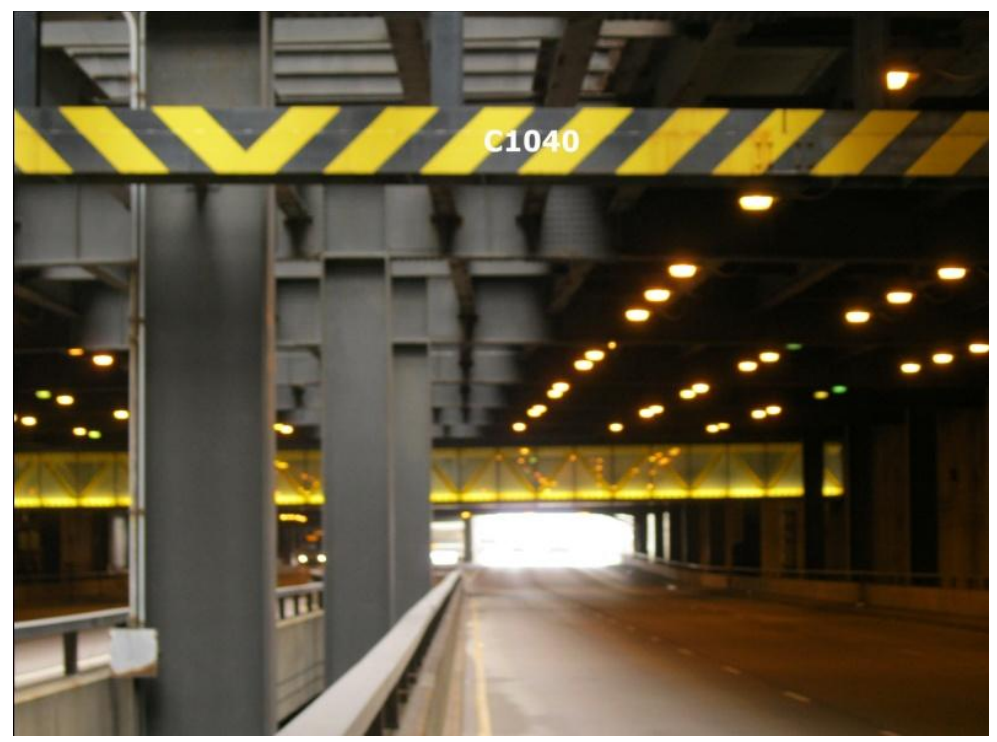

Source: Alfred Benesch \& Company 
Figure B.38 Individual Elements: C1050 Drainage Systems

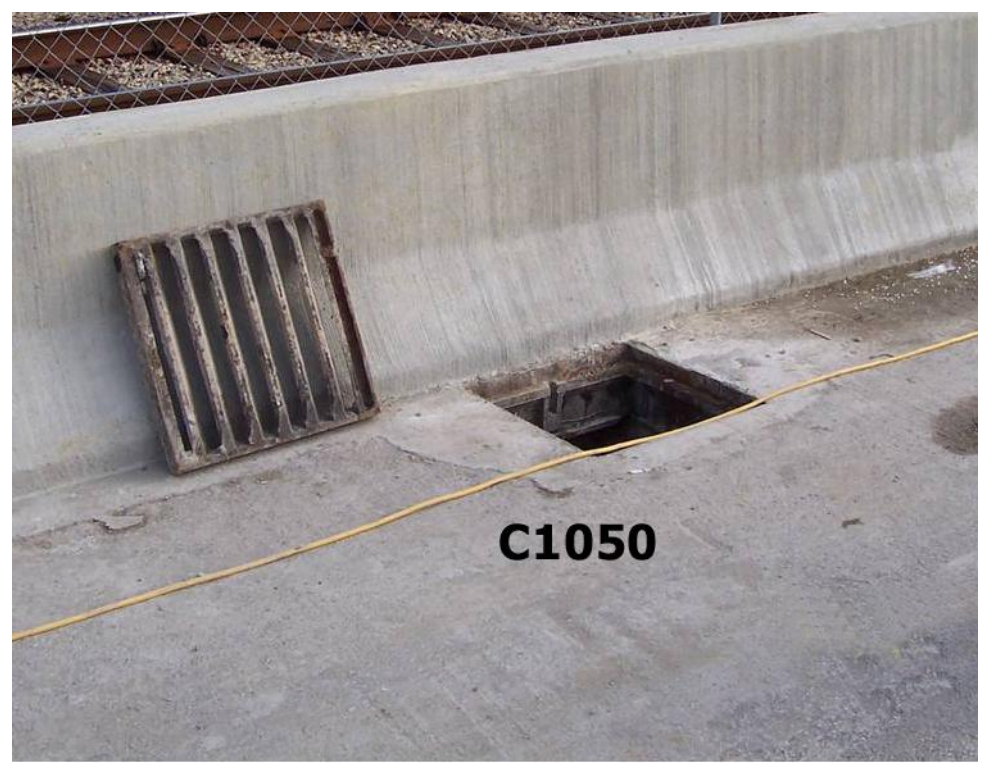

Source: Alfred Benesch \& Company

Figure B.39 Individual Elements: C1050 Drainage Systems (Sub-Elements C105030 Buried Drains (C10503020 Head Walls, C10503030 End Walls))

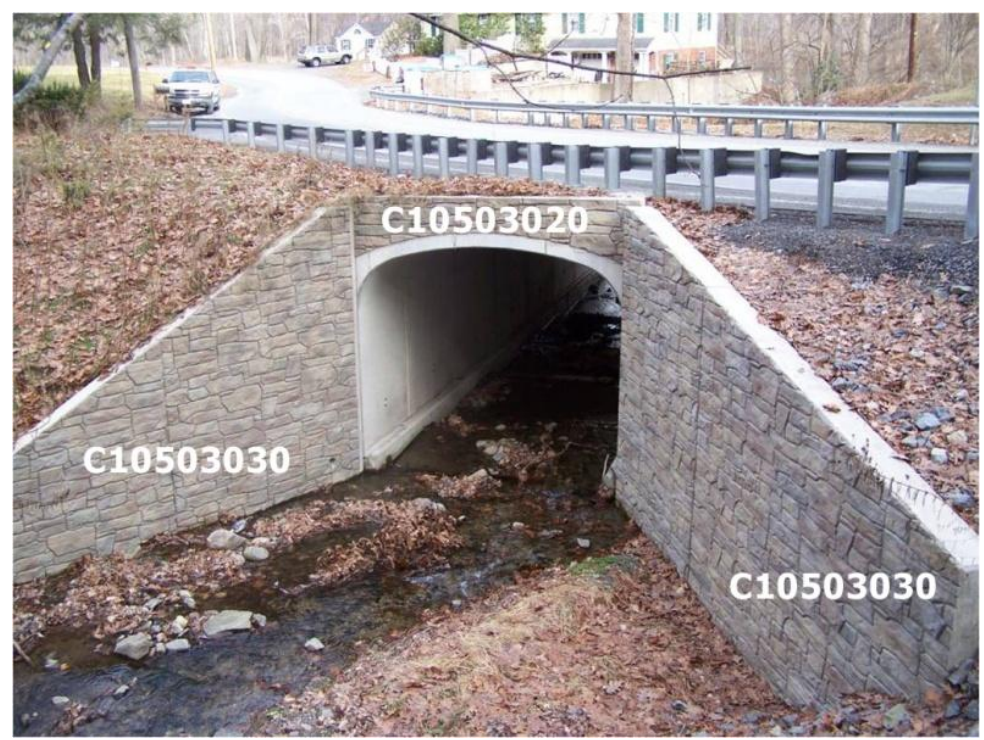

Source: Alfred Benesch \& Company 
Figure B.40 Individual Elements: C1060 Inspection and Maintenance Systems

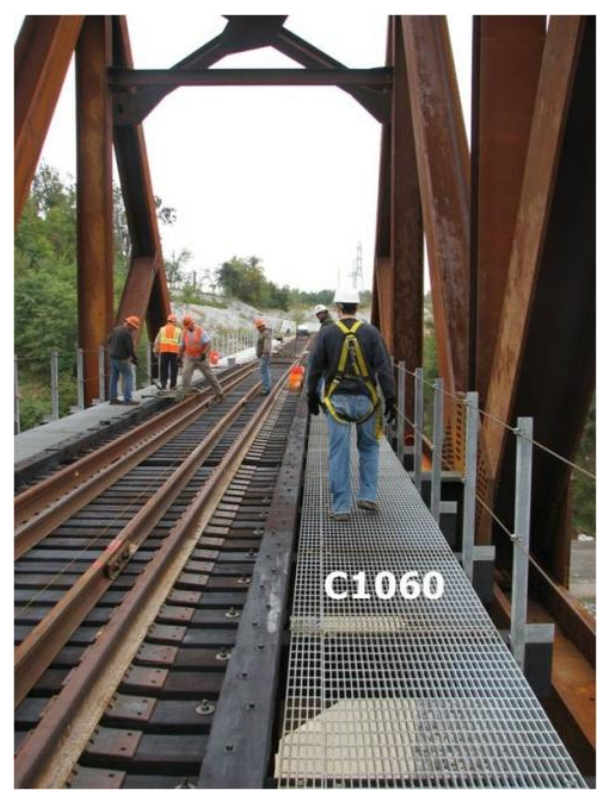

Source: Alfred Benesch \& Company

Figure B.41 Individual Elements: C2010 Barriers
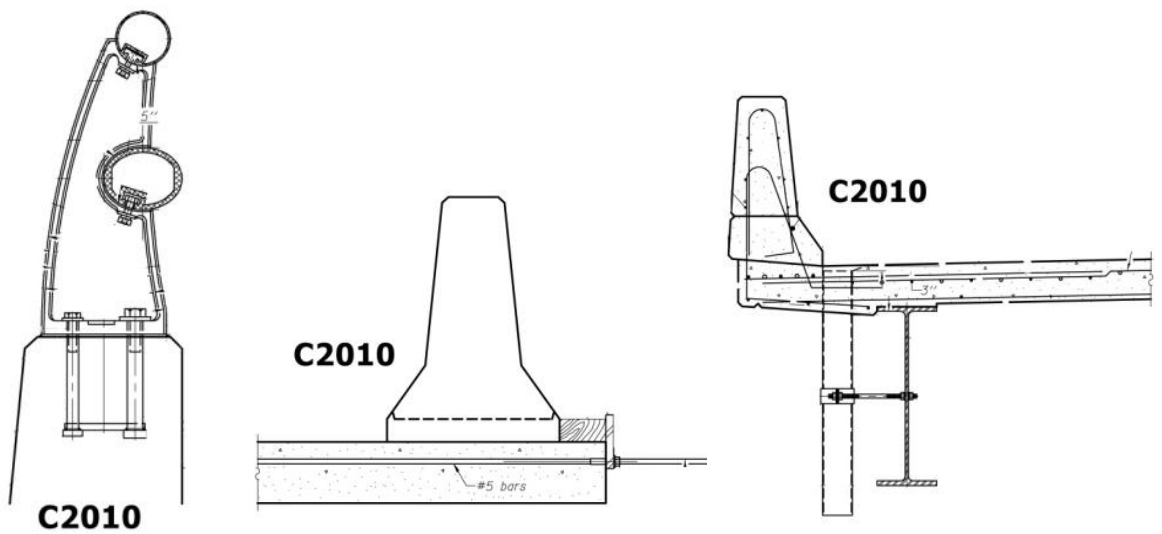

Source: Illinois Department of Transportation 
Figure B.42 Group Elements: C30 Other Protection (Individual Elements: C3010 Lighting)
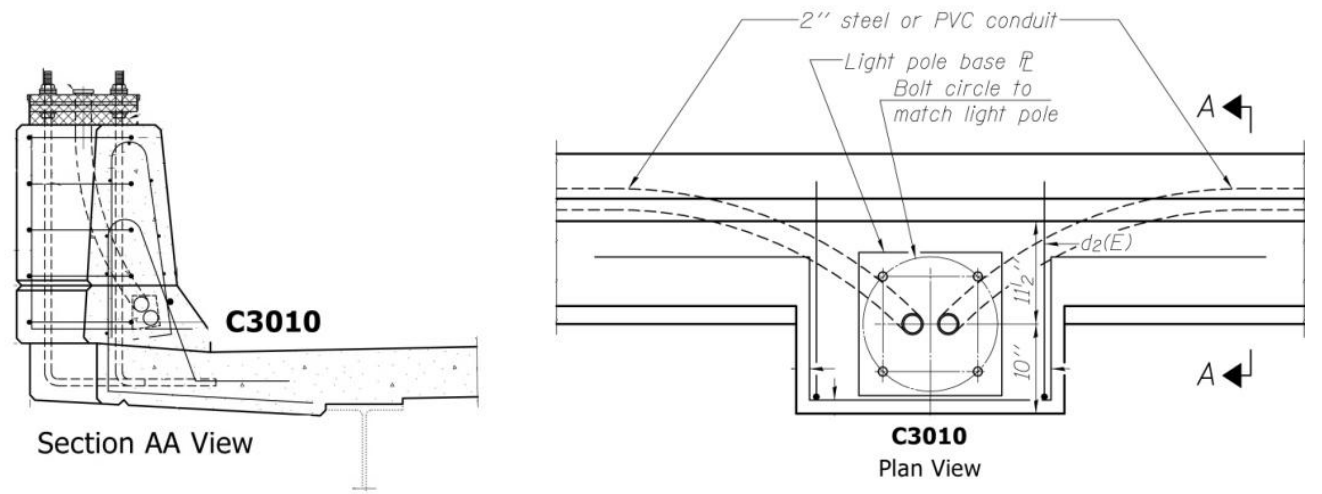

Source: Illinois Department of Transportation

Figure B.43 Individual Elements: C3010 Lighting, C3020 Signage

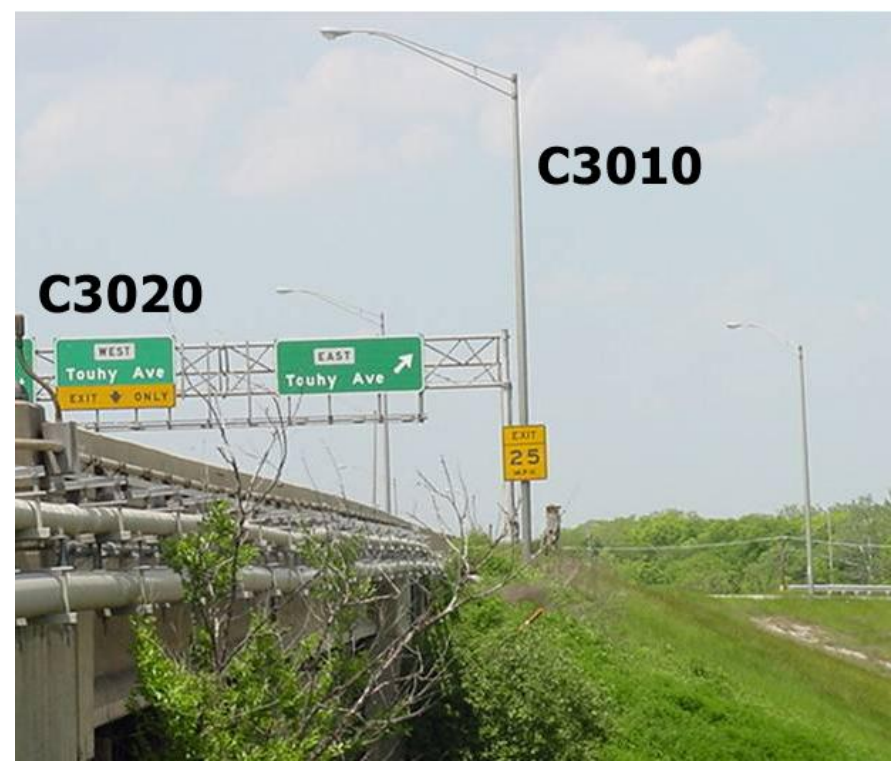

Source: Alfred Benesch \& Company 
Figure B.44 Individual Elements: C3020 Signage

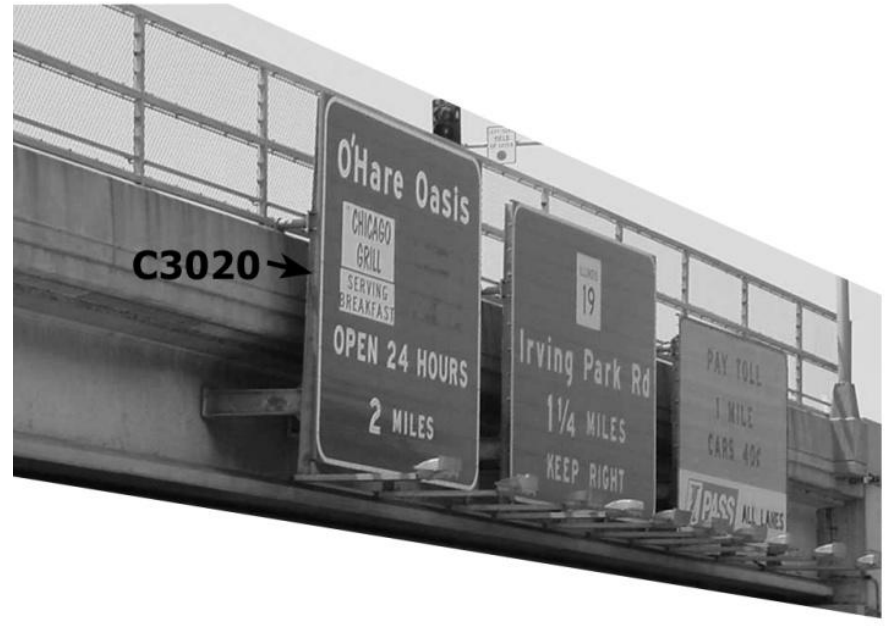

Source: Alfred Benesch \& Company

Figure B.45 Individual Elements: C3030 Sound Barrier Walls

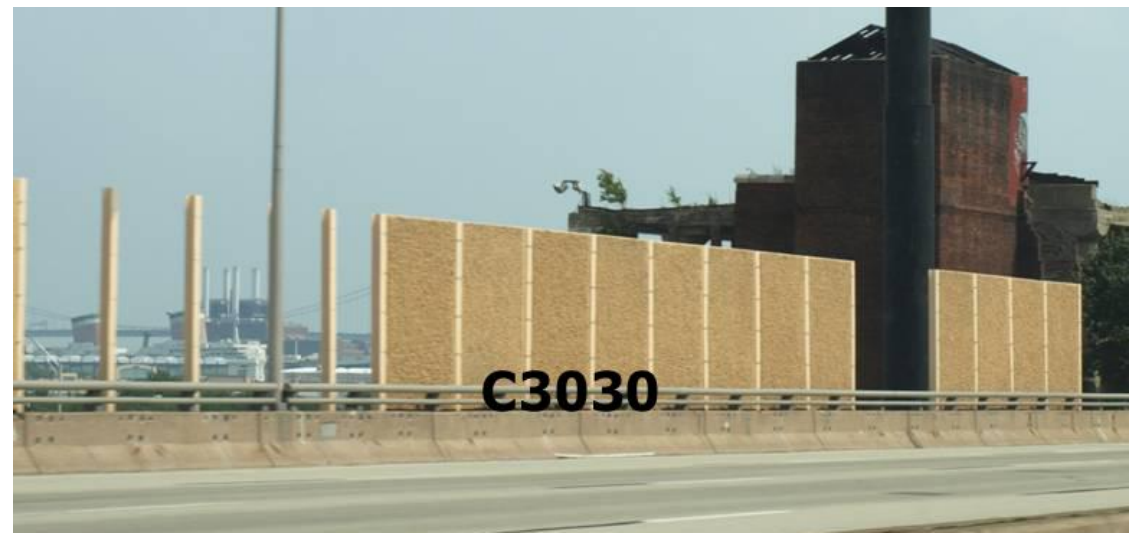

Source: Alfred Benesch \& Company 
Figure B.46 Individual Elements: C3050 Enclosure

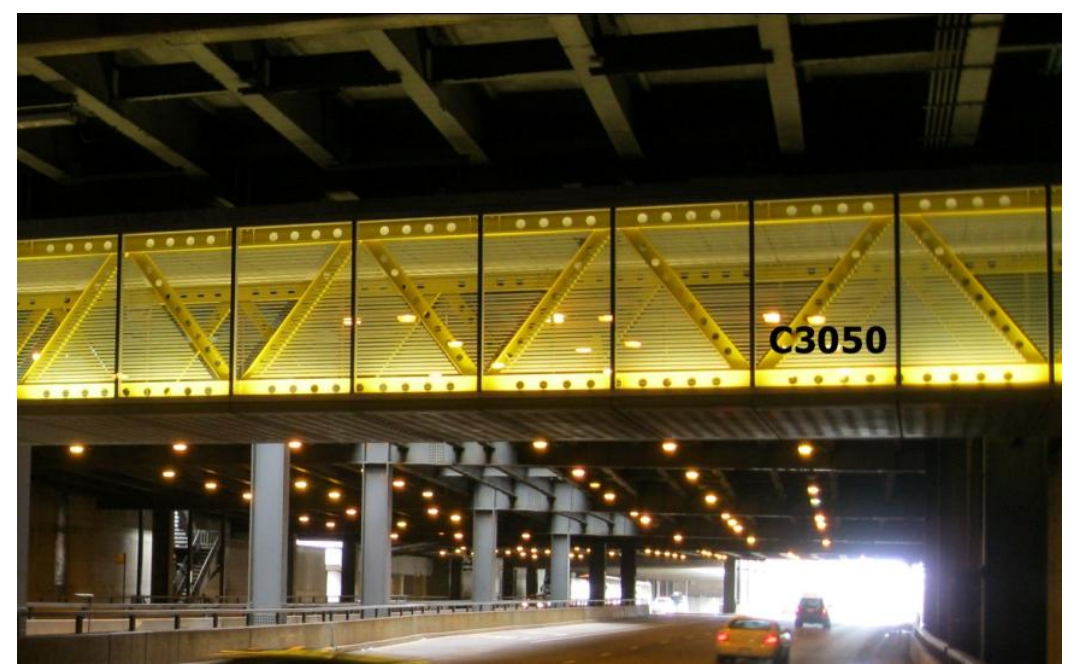

Source: Alfred Benesch \& Company

Figure B.47 Major Elements: D Sitework (Group Elements: D10 Site Preparation (Individual Elements: D1010 Clearing and Grubbing))

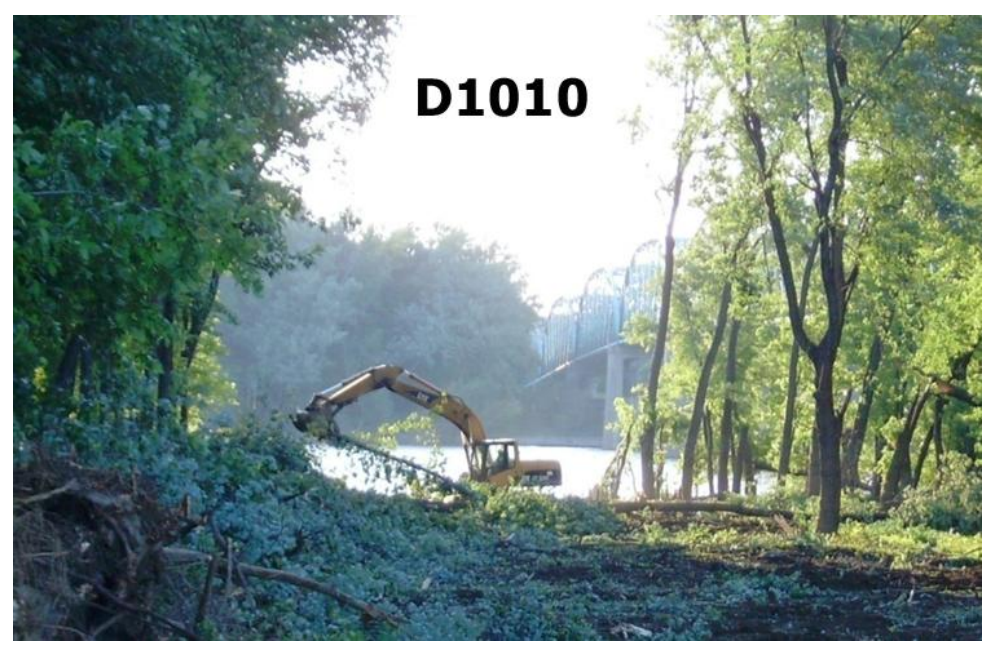

Source: Alfred Benesch \& Company 
Figure B.48 Individual Elements: D1010 Clearing and Grubbing (Sub-Element D101010 Clearing (Tree Removal))

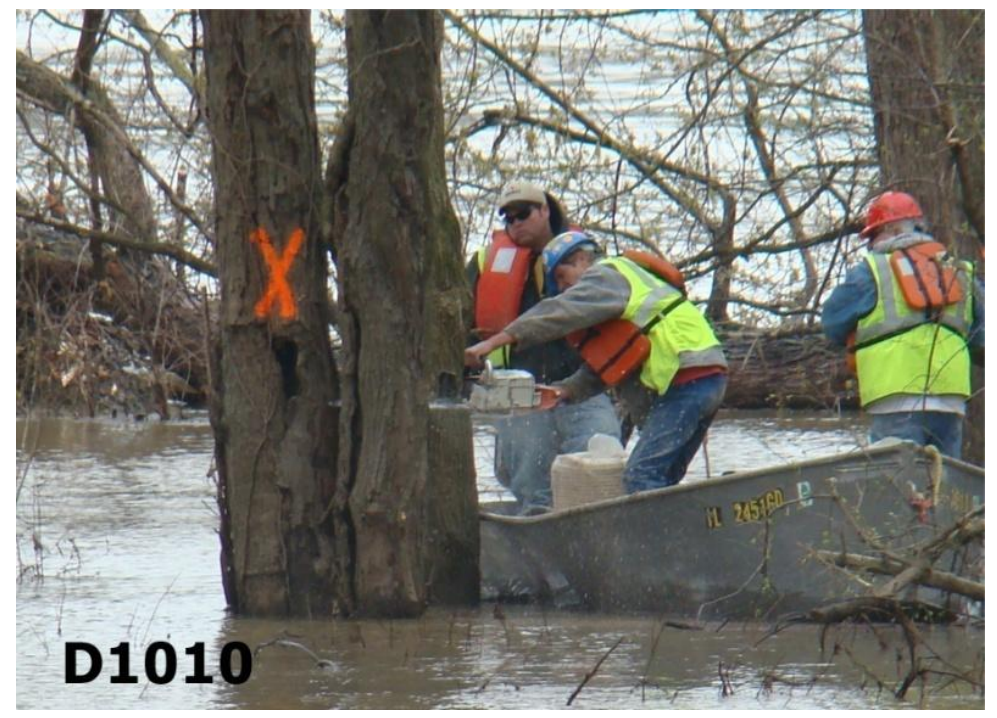

Source: Alfred Benesch \& Company

Figure B.49 Group Elements: D10 Site Preparation (Individual Elements: D1020 Demolition and Relocation)

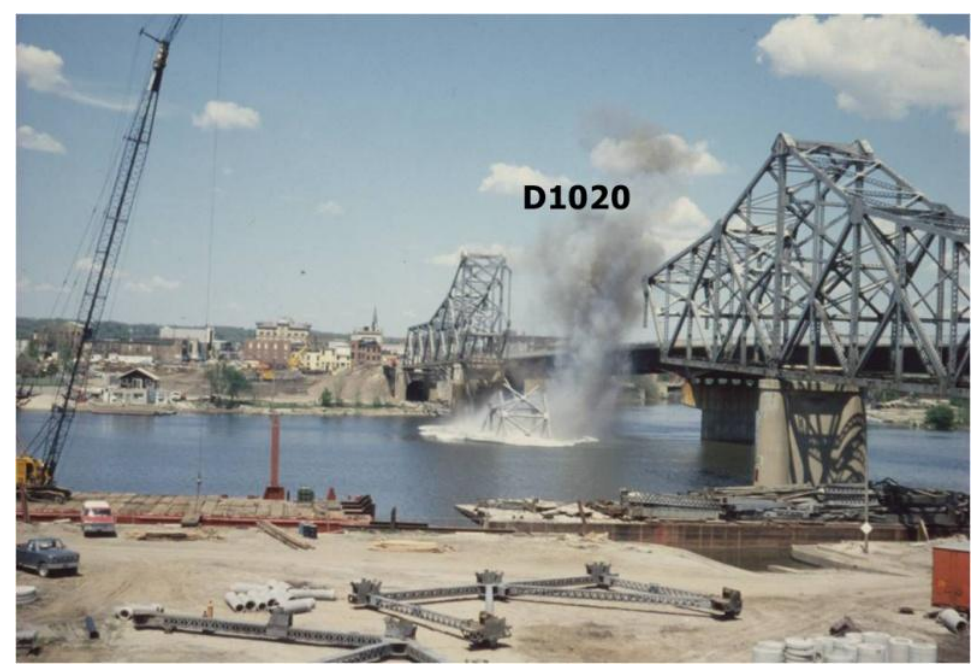

Source: Alfred Benesch \& Company 
Figure B.50 Individual Elements: D1020 Demolition and Relocation

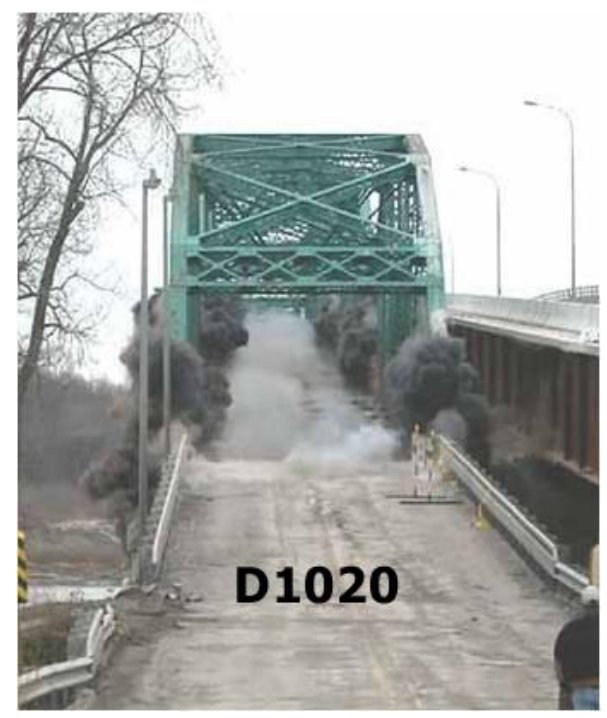

Source: Alfred Benesch \& Company

Figure B.51 Individual Elements: D1030 Earthwork

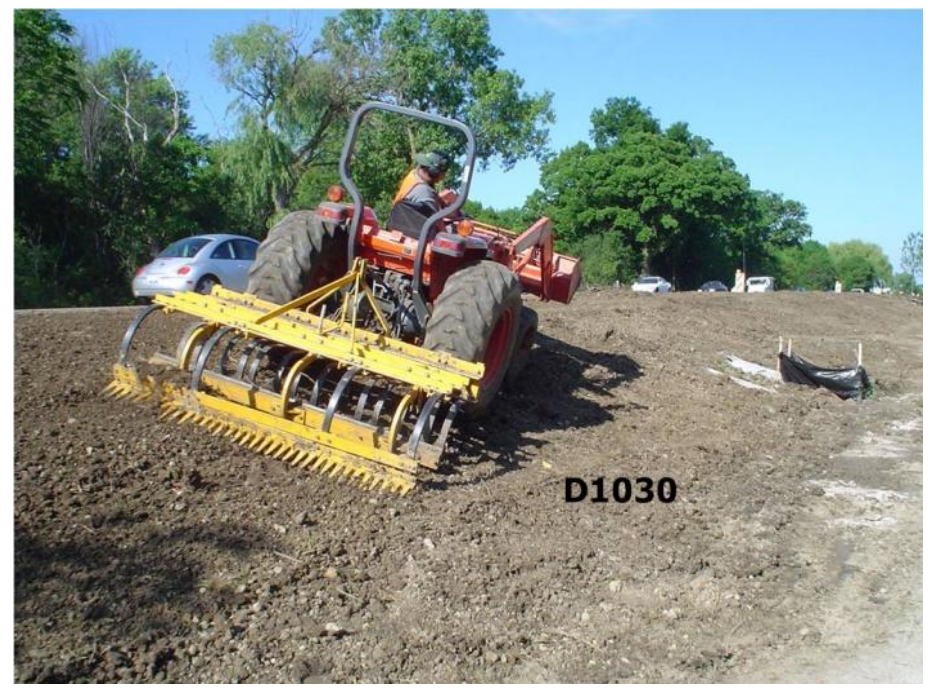

Source: Alfred Benesch \& Company 
Figure B.52 Group Elements: D20 Approach Construction (Individual Elements: D2010 Approach Slabs, D2020 Sleeper Slabs)
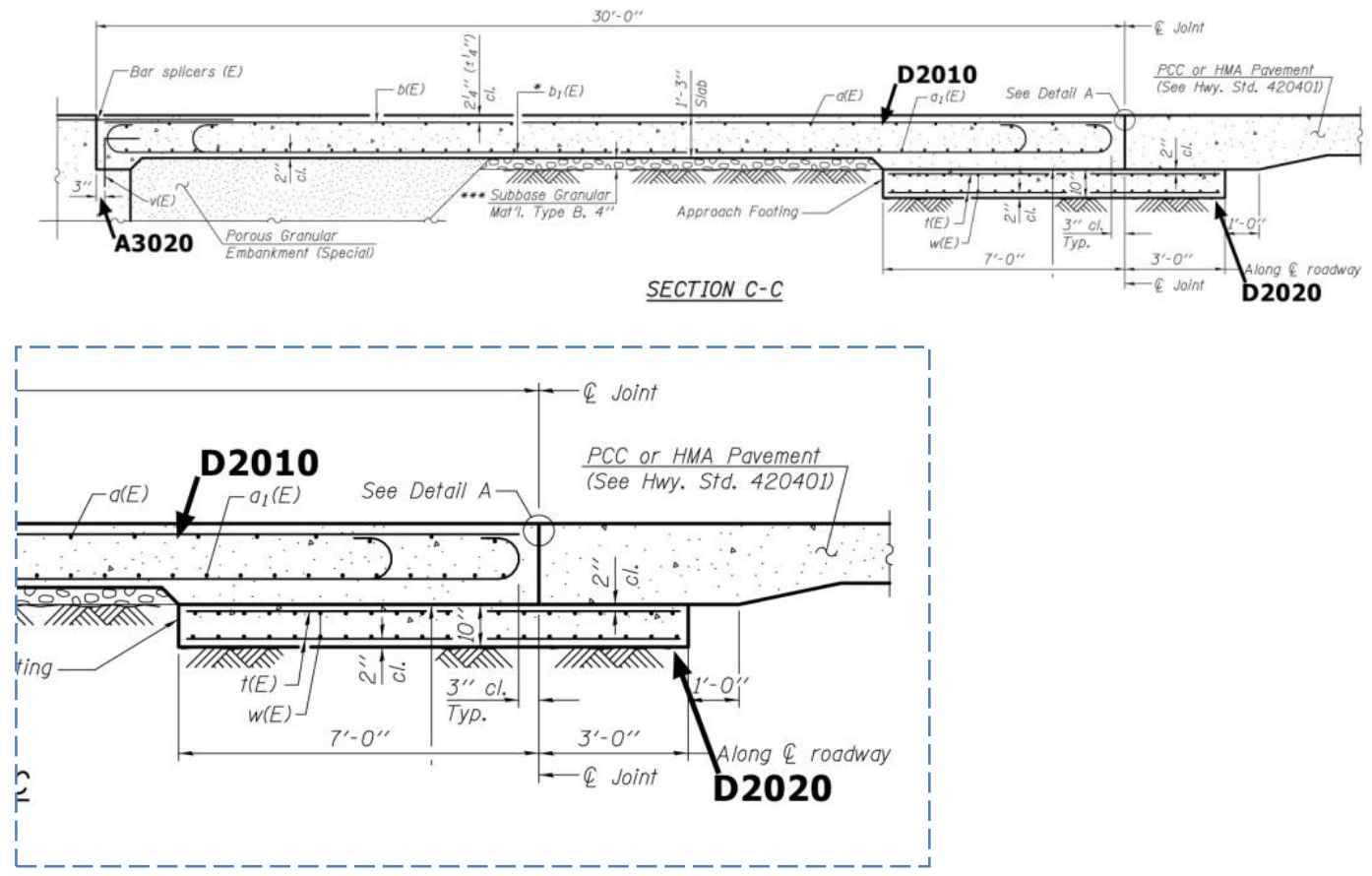

Source: Illinois Department of Transportation

Figure B.53 Individual Elements: D2030 Earth Retention System

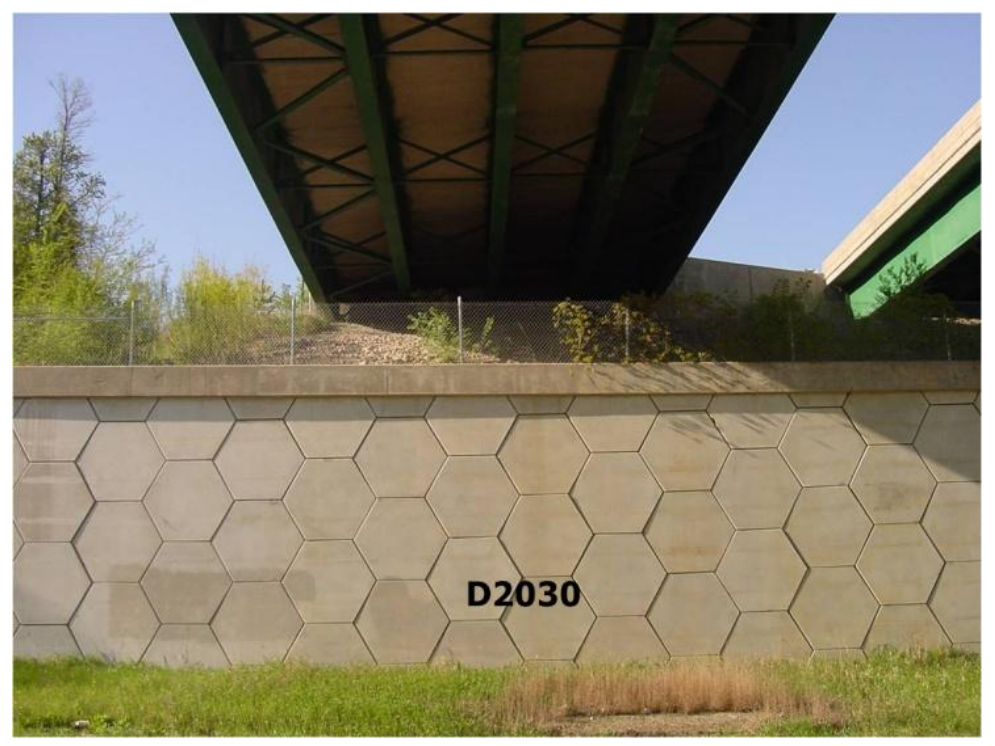

Source: Alfred Benesch \& Company 


\section{Appendix C Application of Proposed UNIFORMAT II Classification and Sub-Classifications to a Single-Span, Modified Tied-Arch Bridge}

\section{C.1 Summary of Key Bridge Characteristics}

This appendix uses a case study bridge construction project to demonstrate how to use the proposed UNIFORMAT II classification and sub-classifications to analyze and manage bridge design and construction costs. The bridge is a dual single-span, modified tied-arch carrying six lanes of Interstate 94 (I-94) traffic (three eastbound and three westbound) over Telegraph Road in Taylor, Michigan. Figure C.1 provides an overhead view of the two bridge structures. This bridge was part of the reconstruction of I-94 for the Super Bowl XL game held in 2006. Figures C. 2 and C.3 provide different perspectives of the bridge as seen from Telegraph Road (Figure C.2) and from I-94 (Figure C.3).

\section{Figure C.1 Overhead View of the Gateway Arch Bridge}

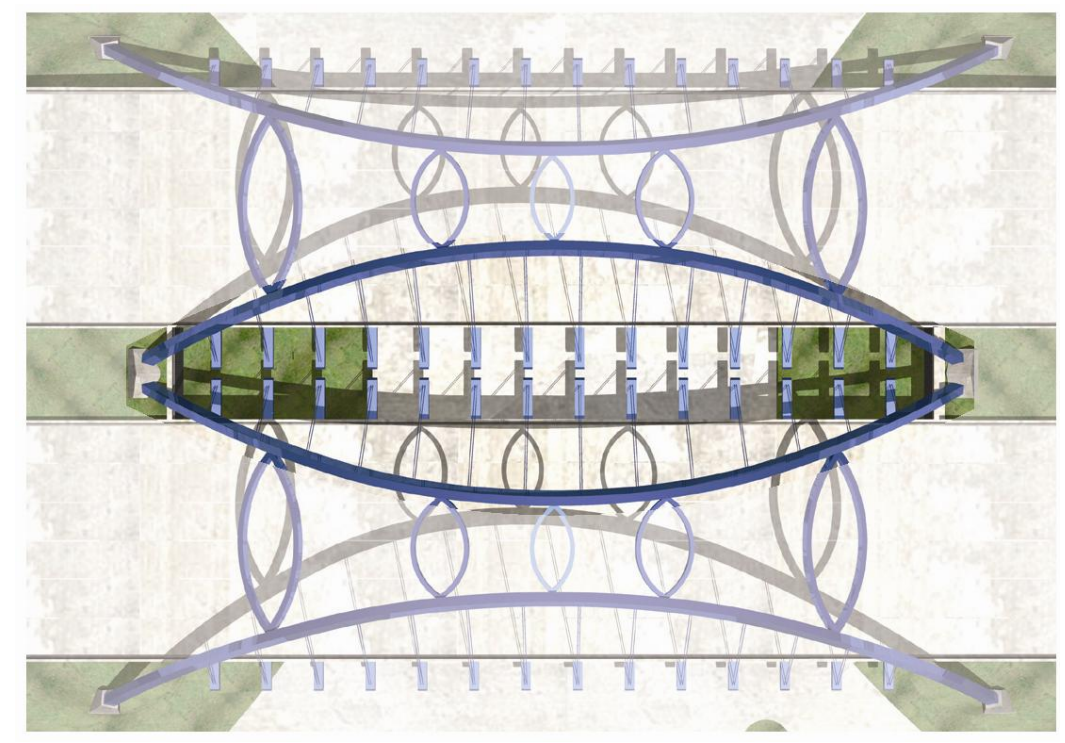

Source: Alfred Benesch \& Company

Many modern bridges are either true arches or tied arches. The modified tied-arch bridge in Taylor, Michigan, combined the two concepts for aesthetic and safety reasons. Tied arches, where the tie is exposed, might be hit by trucks and are not desirable for grade separation structures. True arches, where the thrust must be taken by the foundation elements, are exposed to risk when the soil conditions are poor. The Gateway Arch, as it is now called, is a signature structure modified to look like a true arch with a tied foundation. The thrust blocks are connected below the roadway by a rectangular concrete tie beam. The arch ribs are unequal to keep the two bridges closer together. The stiffness of the ribs is varied to keep the same deflection. To allow for inspections without disturbing the heavy traffic on I-94, the ribs were sealed and pressurized. Pressure gauges were added to detect any leaks. 
Figure C.2 Gateway Arch Bridge as Seen from Telegraph Road

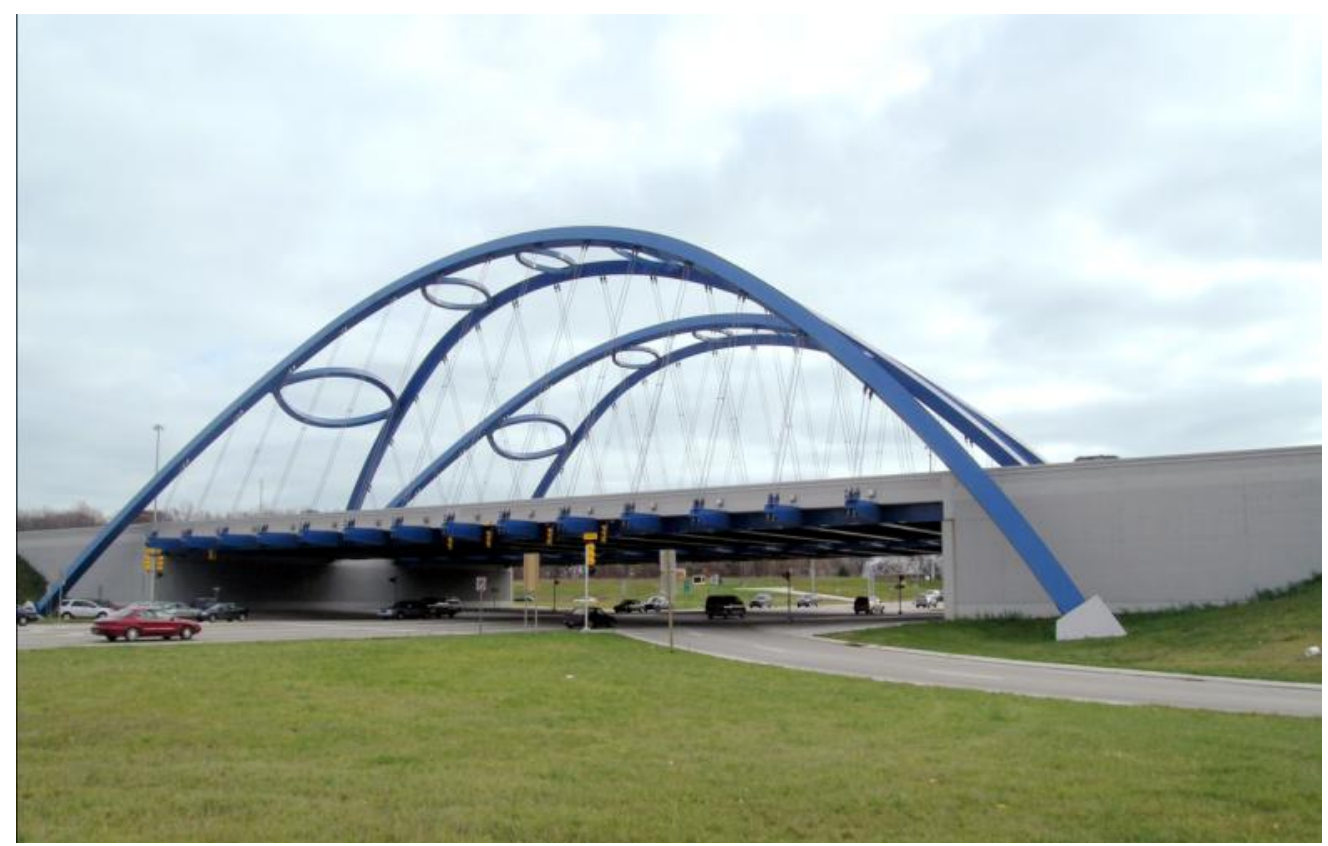

Source: Alfred Benesch \& Company

Figure C.3 Gateway Arch Bridge as Seen from I-94

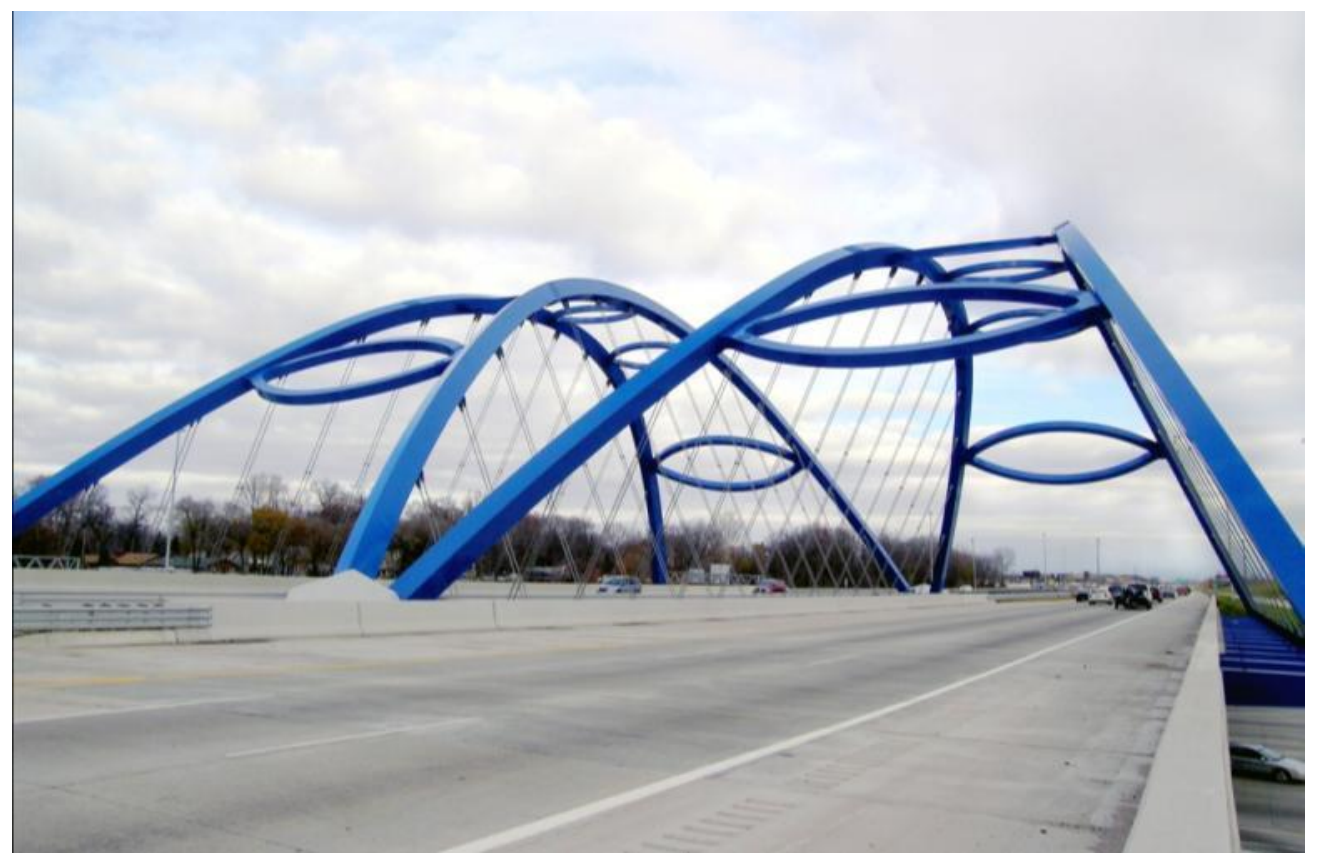

Source: Alfred Benesch \& Company 
The project team was challenged with two major criteria: cost and structural integrity. The team approached the design by analyzing its functions and its worth. The team value engineered the conventional design of elements and identified the function, cost, and performance of each element using ASTM Standard Practice E 2013. ${ }^{41}$ If the function need/performance is high and cost is low, it has value. If the function need/performance is low and cost is high, it becomes a mismatch. When mismatches of conventional design are identified, the team develops innovative solutions to create value of the elements that has a higher need/performance at a lower cost.

\section{Unique Foundation System}

In true arches, the thrust is taken by the foundation supports, such as piles. In tied arches, the thrust is taken internally by tie beams. There is no redundancy in case of a failure of the thrust resistance. For this modified tied-arch, the longitudinal arch thrust is resisted by multiple foundation elements as shown in Figure C.4: the longitudinal foundation ties, the transverse foundation ties, and battered piles. The concrete foundation ties, buried beneath Telegraph Road (see the photograph on the right-hand side of Figure C.4), are sized so that the tensile strength of the concrete is sufficient to carry the arch thrust. However, should the concrete crack, there is adequate reinforcement in the tie. There are also $10 \mathrm{~cm}$ ( $4 \mathrm{in}$ ) diameter open ducts cast in concrete ties. At present, these are capped but the tie can be post-tensioned if deemed necessary. In addition, battered piles and massive earth pressure against the foundation also resist arch thrust.

\section{Figure C.4 Gateway Arch Bridge Foundation System}

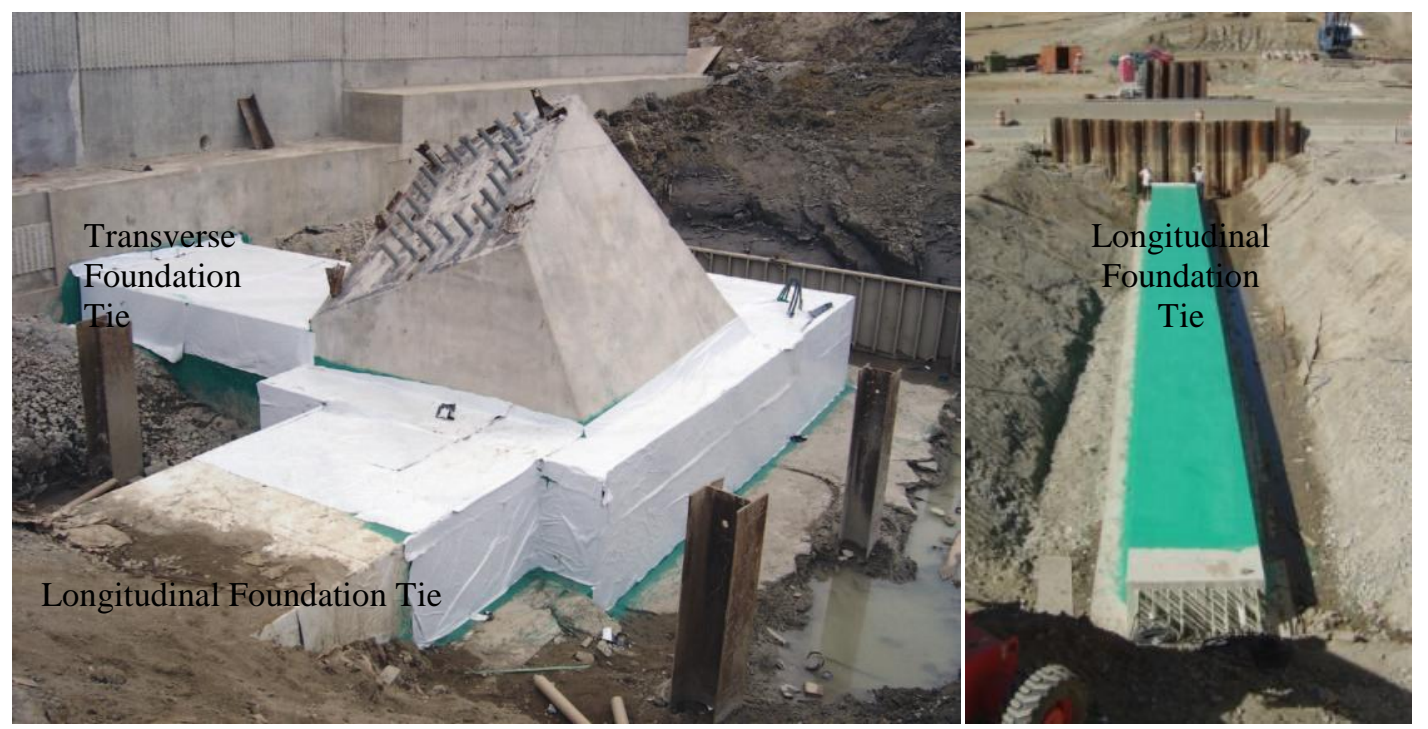

Source: Alfred Benesch \& Company

\footnotetext{
${ }^{41}$ ASTM International. "Practice for Constructing FAST Diagrams and Performing Function Analysis During Value Analysis Study," E 2013, op cit.
} 
Each structure is a single-span inclined through arch. The interior and exterior arch ribs are inclined 25 degrees towards each other. The inclination is limited to 25 degrees in order to maintain the desirable vertical clearance. The ribs are braced together using five football shaped braces (see Figures C.5 and C.6). The bases of the exterior arch ribs are located at the Telegraph Road level, while the bases of the interior ribs are located at the I-94 level. This caused the length of the exterior rib and the interior rib to be different. The length of the exterior and interior arch ribs are $90.2 \mathrm{~m}(296 \mathrm{ft})$ and $78.3 \mathrm{~m}(257 \mathrm{ft})$, respectively. The span length measured between the east and west abutments is $75.0 \mathrm{~m}$ $(246 \mathrm{ft})$.

\section{Figure C.5 Longitudinal View of the Arch Ribs}

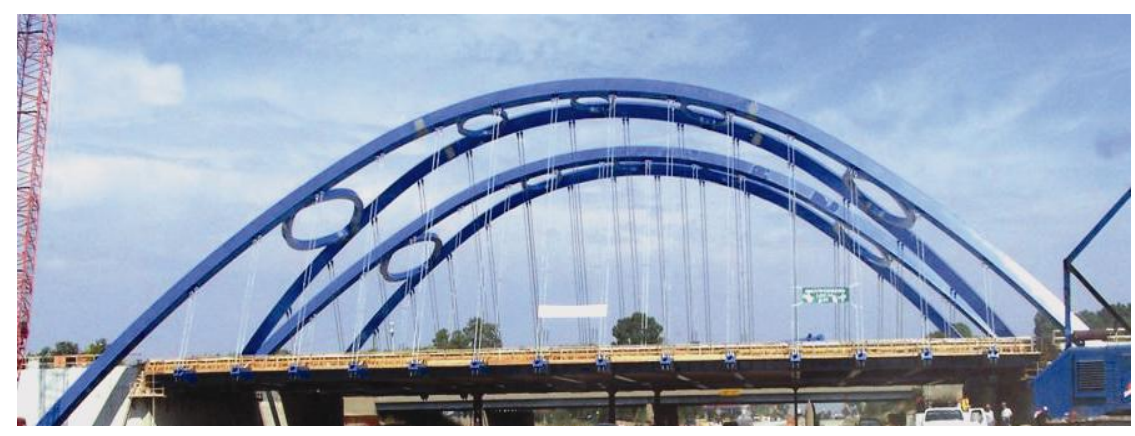

Source: Alfred Benesch \& Company

The unequal lengths of the arches posed a challenge to the design team. The arch rib deflection due to dead and live loads will be different. By carefully varying the stiffness of the box while maintaining the outside shape and dimension the same, both the appearance and structural integrity were achieved. The inner thrust block is at the road level of I-94; the outer thrust block is at the level of Telegraph Road. 
Figure C.6 Transverse View of the Arch Ribs Illustrates Unequal Lengths

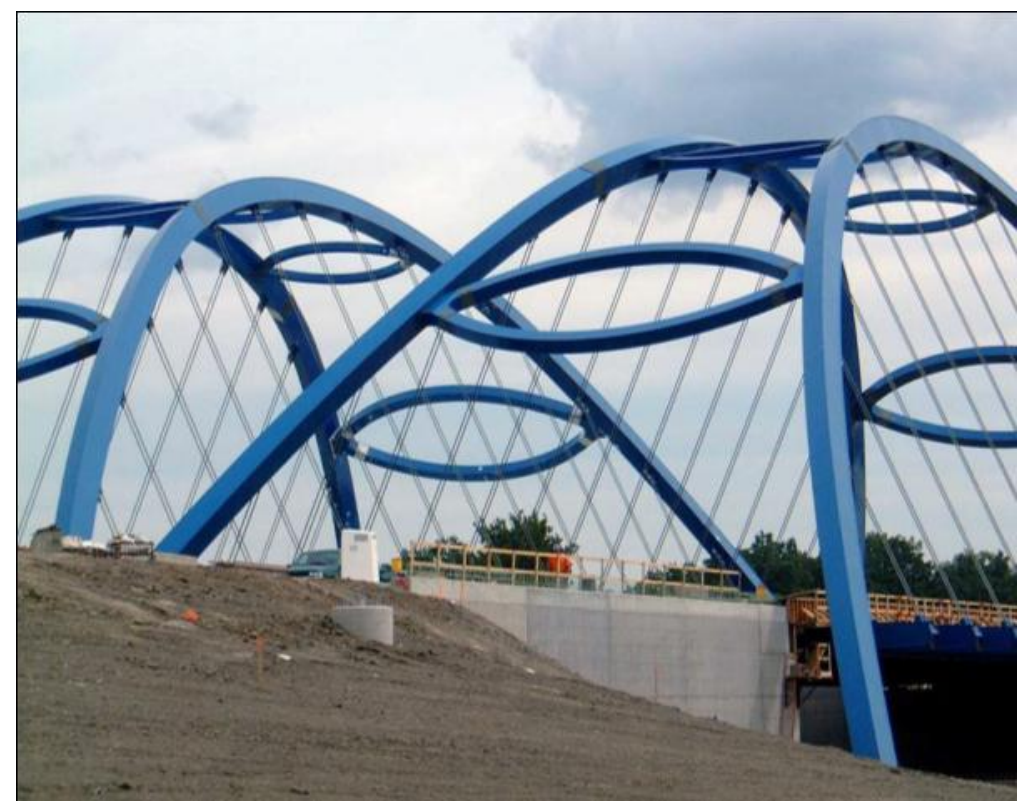

Source: Alfred Benesch \& Company

The ribs are fixed at each end by the foundation. The arch ribs are a $0.9 \mathrm{~m}$ by $1.2 \mathrm{~m} \mathrm{(3 \textrm {ft }}$ by $4 \mathrm{ft}$ ) box section. The webs of the ribs are $1.91 \mathrm{~cm}(0.75 \mathrm{in})$ thick. The flanges for the exterior ribs and interior ribs are $6.35 \mathrm{~cm}(2.5 \mathrm{in})$ thick and $5.72 \mathrm{~cm}(2.25 \mathrm{in})$ thick, respectively.

\section{Maintenance of Arch Ribs}

Due to the small size of the arch ribs, future inspection and maintenance of the inside portion of the box is virtually impossible. Therefore, the arch ribs, arch braces, and the boxed-sections of transverse beams are pressurized with dry air to prevent moist air from entering the boxed-sections to cause corrosion. In order to prevent any air leakage from the pressurized sections, the top flanges of the arch ribs and braces are welded to the webs using a full penetration weld. The bottom flanges are welded to the webs using a double side fillet weld. A trapezoidal shape-sealing diaphragm is located inside the arch box at each hanger location. The portion inside the sealing diaphragm is not pressurized, and an access opening in the web is provided to facilitate inspection of the unsealed portion of the arch. 


\section{Figure C.7 Access Opening to the Arch Rib}
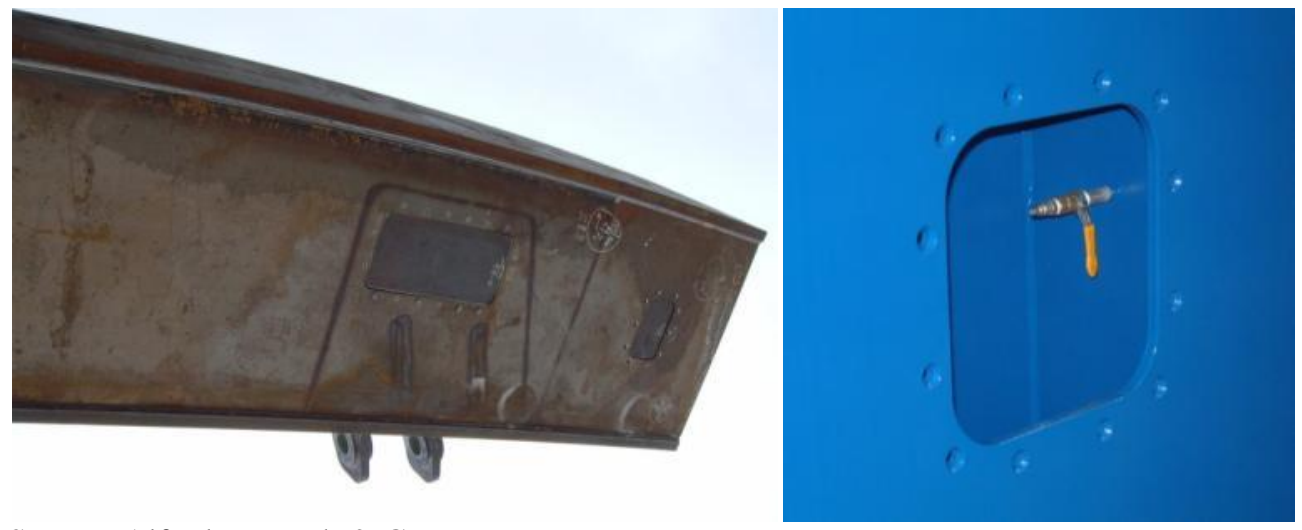

Source: Alfred Benesch \& Company

Access openings in the arch ribs are furnished where the air pressure can be checked (see Figure C.7). At each arch rib field splice location, one pressure valve is attached to the sealing diaphragm. The arch rib segments are sealed and pressurized with air at 55.2 kilopascal (kpa) (8.0 pounds per square inch (psi)). If the pressure inside the sealed chamber drops by more than $10.3 \mathrm{kpa}(1.5 \mathrm{psi})$ from the $55.2 \mathrm{kpa}(8 \mathrm{psi})$ norm, then the reason for the air leak should be investigated.

\section{Redundancy of Hanger Assembly}

Each arch has 14 hanger assemblies that transfer the loads from the deck to the arch ribs. The hanger assembly posed a number of challenges. First, the hangers were changed from rods to strands. Because the hangers are a critical element in carrying the load, it was decided to increase the redundancy. Thus, each hanger assembly has a pair of strands, each one capable of carrying the total load (see the photograph on the left-hand side of Figure C.8).

\section{Figure C.8 Hanger Assembly and Neoprene Transition Boots}

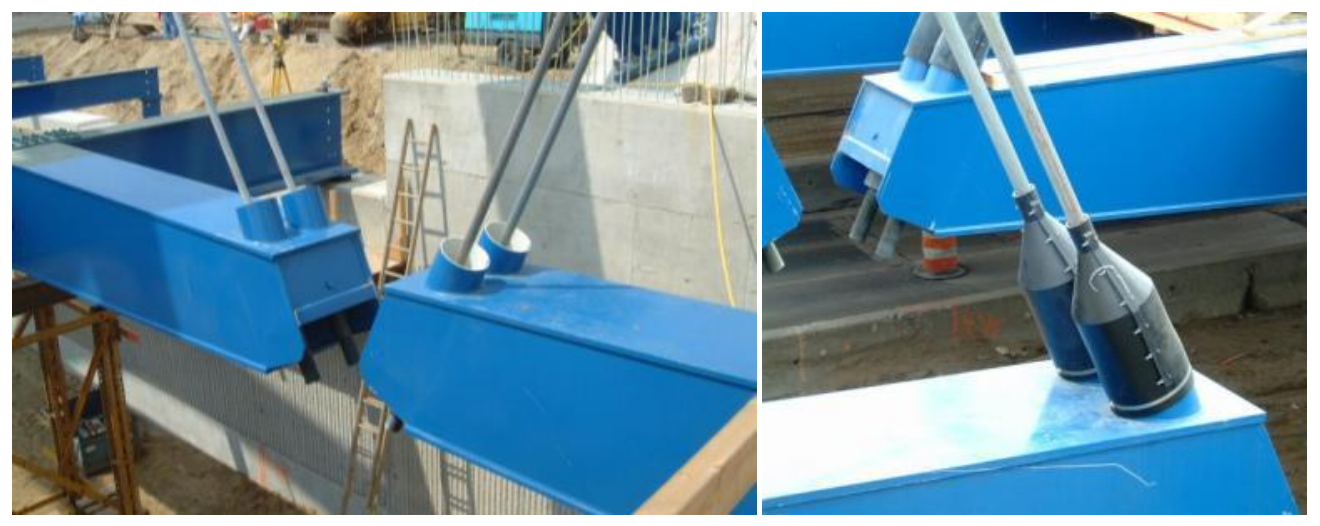

Source: Alfred Benesch \& Company 
Each hanger assembly consists of two $5.4 \mathrm{~cm}$ (2.125 in) diameter, ASTM A586 structural stands, spaced $38.1 \mathrm{~cm}$ (15 in) center to center. The inner wires of each strand are galvanized with Class A coating, while the outer wires are galvanized with Class $\mathrm{C}$ coating. Each strand is attached to the arch ribs using a $4.45 \mathrm{~cm}$ (1.75 in) thick hanger support plate and ASTM A148 Grade 105/85 galvanized open type socket.

Neoprene transition boots, secured to $25.4 \mathrm{~cm}$ (10 in) diameter standard pipe, welded to the transverse beams and to the strands using stainless steel clamps, are used to prevent moisture from entering inside the connections between the transverse beams and the strands and to enhance aesthetics (see the photograph on the right-hand side of Figure C.8). A hanger separator is installed between the two strands of each hanger assembly for the middle ten hangers. Hanger separators increase in-plane stiffness of the strands by constraining the relative motions between them and increasing the stiffness of the hanger against transverse winds.

The bridge was designed to facilitate the replacement of individual strands. Each strand of the pair is capable of supporting the deck and the full live load while the other is replaced.

\section{C.2 Cost Accounting Framework}

The costs of each element are organized around the proposed UNIFORMAT II classification of bridge elements, as described in Table 2.3. Because these costs have associated with them project management functions and risk management functions, two additional tables are needed. Table C.1 covers program management-related costs and Table C. 2 covers risk management-related costs. Each table is organized as a three-level hierarchy. 
Table C.1 Classification Hierarchy for Program Management-Related Costs

\begin{tabular}{|c|c|c|}
\hline $\begin{array}{l}\text { Level } 1 \\
\text { Major Group Classification }\end{array}$ & $\begin{array}{l}\text { Level } 2 \\
\text { Group Classification }\end{array}$ & $\begin{array}{c}\text { Level } 3 \\
\text { Individual Classification }\end{array}$ \\
\hline $\mathrm{X}$ Project Management & X10 Field Requirements & $\begin{array}{l}\text { X1005 } \text { Bonds, Permits, Fees, and Insurance } \\
\text { X1010 Field/Site Set-Up and Accommodation } \\
\text { X1015 Management, Supervision, and Field Engineering } \\
\text { X1020 Personnel Travel and Lodging } \\
\text { X1025 Safety and Protection } \\
\text { X1030 Construction Aids, Equipment, and Tools } \\
\text { X1035 Temporary Construction } \\
\text { X1040 Climatic and Environmental Requirements } \\
\text { X1045 Quality Control, Inspection, and Testing } \\
\text { X1050 Maintenance and Housekeeping } \\
\text { X1090 Other Contractural Requirements }\end{array}$ \\
\hline & X20 Office Overhead and Profit & $\begin{array}{l}\text { X2010 Home Office Overhead } \\
\text { X2020 Profit }\end{array}$ \\
\hline
\end{tabular}

Table C.2 Classification Hierarchy for Risk Management-Related Costs

\begin{tabular}{|l|l|l|}
\hline \multicolumn{1}{|c|}{$\begin{array}{c}\text { Level 1 } \\
\text { Major Group Classification }\end{array}$} & \multicolumn{1}{c|}{$\begin{array}{c}\text { Level 2 } \\
\text { Group Classification }\end{array}$} \\
\hline Y Risk Management & Y10 Allowance & $\begin{array}{l}\text { Y1010 Specific } \\
\text { Y1020 Nonspecific }\end{array}$ \\
\cline { 2 - 3 } & Y20 Contingency & $\begin{array}{l}\text { Y2010 Specific } \\
\text { Y2020 Nonspecific }\end{array}$ \\
\cline { 2 - 3 } & & $\begin{array}{l}\text { Y3010 Specific } \\
\text { Y3020 Nonspecific }\end{array}$ \\
\cline { 2 - 3 } & & \\
& & \\
\end{tabular}


The prefix in Table C. 1 is X indicating its relationship to Table 1 in ASTM E 2083, Standard Classification for Building Construction Field Requirements and Office Overhead and Profit. Level 1 in the hierarchy contains the single entry X Project Management. Level 2 in the hierarchy contains two entries: X10 Field Requirements and X20 Office Overhead and Profit. Level 3 entries under X10 Field Requirements include such cost items as X1030 Construction Aids, Equipment, and Tools (e.g., cranes and scaffolding) and X1035 Temporary Construction (e.g., coffer dams).

The Prefix in Table C.2 is Y indicating its relationship to ASTM E 2168, Standard Classification for Allowance, Contingency, and Reserve Sums in Building Construction Estimating. Due to the unique characteristics of the Gateway Arch Bridge, ASTM E 2168 was of particular importance. Level 1 in the hierarchy contains the single entry $Y$ Risk Management. Level 2 in the hierarchy contains three entries: Y10 Allowance, Y20 Contingency, and Y30 Reserve Sums. The two Level 3 entries under Y10 Allowance are: Y1010 Specific and Y1020 Nonspecific. There are similar breakdowns for Y20 Contingency and Y30 Reserve Sums. For example, under Y20 Contingency, Y2010 Specific covers planning contingency, design contingency, and construction contingency, whereas Y2020 Nonspecific covers overall unexpected events or items. As the project progresses, some of the planning and design contingencies will be moved into the base cost. Construction contingency will remain until the construction is complete.

In addition to the three risk management terms - allowance, contingency, and reserve sums - included in ASTM E 2168, it is useful to introduce a fourth term, base cost. Base cost includes all costs for the construction work including all trade costs and the prime contractor's field requirements and office overhead and profit reported in Table C.1. It is instructive to review the relationship between these four cost terms. Understanding these relationships is at the heart of analyzing and managing design and construction costs for complex projects such as the Gateway Arch Bridge. Base cost plus allowance is designated as the minimum cost. Base cost plus allowance and contingency is designated as the expected cost. Base cost plus allowance, contingency, and reserve sums is designated as the maximum cost.

\section{C.3 Cost Analysis of the Gateway Arch Bridge Using the Proposed UNIFORMAT II Elemental Classification and Sub-Classifications}

The total cost for one of the two bridge structures making up the Gateway Arch Bridge is $\$ 6.76$ million. Since the two bridge structures are identical, their total costs are the same. The cost analysis of the Gateway Arch Bridge using the proposed UNIFORMAT II elemental classification and sub-classifications is presented in Table C.3 and summarized in Figure C.9. Table C.3 records information for each of the five levels in the proposed UNIFORMAT II bridge classification. Table C.3 includes alphanumeric designations and element/sub-element names, dollar values, percent of total cost associated with those dollar values, and unit costs. Figure C.9 records the cost distribution of selected Group Elements and Individual Elements. The costs summarized in Figure C.9 are the major Substructure and Superstructure Group Elements and Individual Elements; they account for approximately $85 \%$ of the Gateway Arch Bridge's total cost. 
Table C.3 Cost Analysis of the Gateway Arch Bridge Using the Proposed UNIFORMAT II Elemental Classification and Sub-Classifications

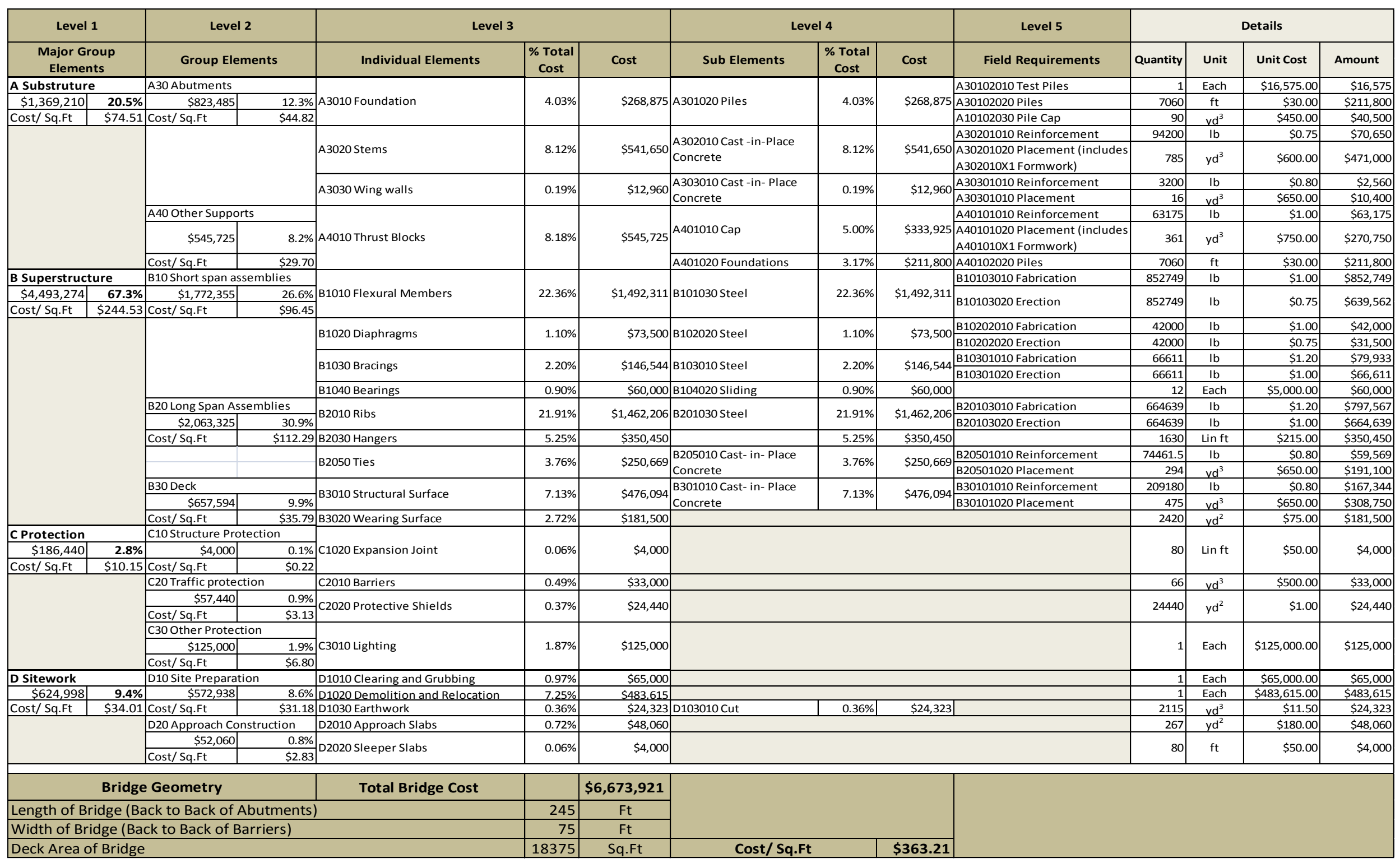


Figure C.9 Cost Distribution of Selected Group Elements and Individual Elements for the Gateway Arch Bridge

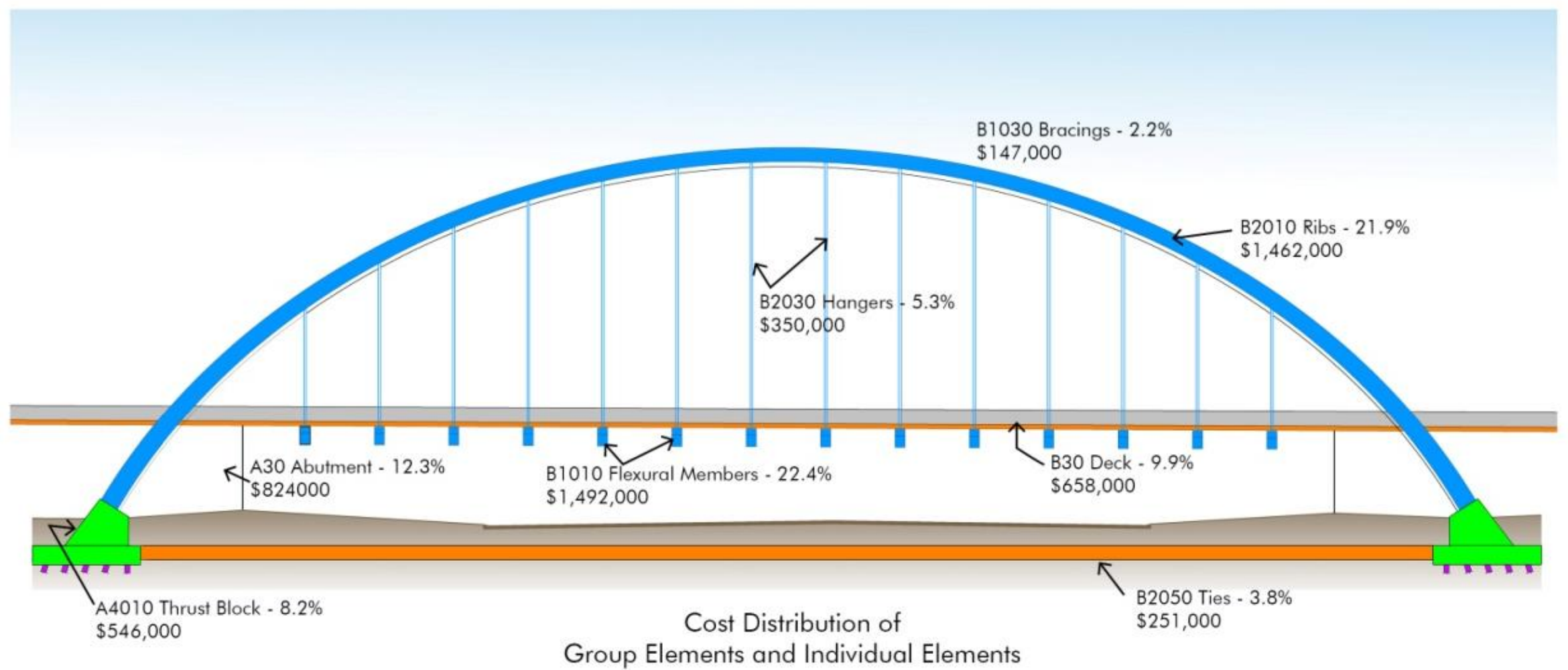

Source: Alfred Benesch \& Company 
Table C.3 is organized so that the costs from each lower level in the UNIFORMAT II hierarchy can be easily aggregated. The first four columns correspond to Levels 1, 2, 3, and 4 of the proposed UNIFORMAT II elemental classification. The last five columns list any Level 5 Sub Elements, as well as item alphanumeric designation and name, quantities, units of measure, unit costs, and item cost. Two intermediate columns summarize the cost characteristics of each Level 4 Sub Element. In several casesB3020 Wearing Surface - the entries correspond to the Level 3 Individual element. The two intermediate columns show the cost of the Level 4 Sub Element, which is obtained by summing over all Level 5 Sub Elements associated with that Level 4 Sub Element, and the per cent of total cost associated with that cost. For example, the Level $4 \mathrm{Sub}$ Element, A301020 Piles, has a cost of $\$ 269000$. Given that the total cost of the bridge is $\$ 6.76$ million, this value represents $4.03 \%$ of the total cost.

The cost of a Level 3 Individual Element is obtained by summing over all of its Level 4 Sub Elements. In a similar fashion, the cost of a Level 2 Group Element is obtained by summing over all of its Level 3 Individual Elements and the cost of a Level 1 Major Group Element is obtained by summing over all of its Level 2 Group Elements. The cost for each Major Group Element and Group Element, along with its per cent of total cost and unit cost, are recorded in the first two columns of Table C.3. Note that some Group Elements have a single Level 3 Individual Element. For example, Group Element A40, Other Supports, has a single Individual Element, A4010 Thrust Blocks. In such cases the values recorded under the Level 2 Group Element heading correspond to those associated with the Level 3 Individual Element.

The values recorded in Table C.3 provide the basis for Figure C.9. Figure C.9 presents a cost distribution of selected Group Elements and Individual Elements tied to a graphical representation of a longitudinal view of the Gateway Arch Bridge. The figure includes the alphanumeric string, the name of the Group Element or Individual Element, its cost, and its per cent of total cost. Two Group Elements and six Individual Elements are highlighted in Figure C.9. Reference to Figure C.9 reveals that the Level 2 Group Element A30 Abutment has a cost of $\$ 824000$, which corresponds to $12.3 \%$ of the total cost. The other Level 2 Group Element shown in Figure C.9, B30 Deck, has a cost of $\$ 658000$ or $9.9 \%$ of total cost. Two Individual Elements, B1010 Flexural Members and B2010 Ribs, are of particular importance, since they each represent more than $20 \%$ of the total cost of the bridge. Table C.3 and Figure C.9 illustrate how the proposed UNIFORMAT II elemental classification can be used to focus attention on those elements that drive the overall costs of a bridge project, as well as those elements that are associated with special characteristics - in this case the unique foundation system - of a particular bridge.

The Gateway Arch Bridge won six awards, including two national awards. The two national awards were the 2006 Outstanding Project Award from the National Council of structural Engineers Association and the 2007 Prize Bridge-Medium Span Award from the National Steel Bridge Alliance. In addition to the two national awards, the Gateway Arch Bridge won the 2006 Best Medium Structure Award from the Structural Engineers Association of Illinois; the 2006 Engineering Honorable Conceptor Award from the 
Michigan Chapter of the American Council of Engineering Companies; the 2008

Partnering Award from the Michigan Construction Quality Partnership; and the 2008 Making a Difference Gold Award for Partnering from the National Partnership for Highway Quality. A major criterion for its selection as an award recipient was its cost effectiveness. 